


$$
\begin{aligned}
& 375.88 \\
& 4763 \\
& 100469
\end{aligned}
$$

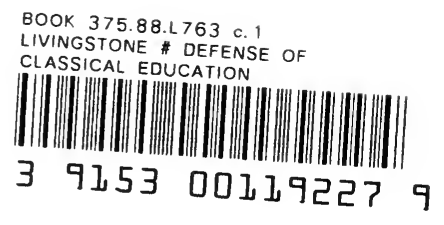




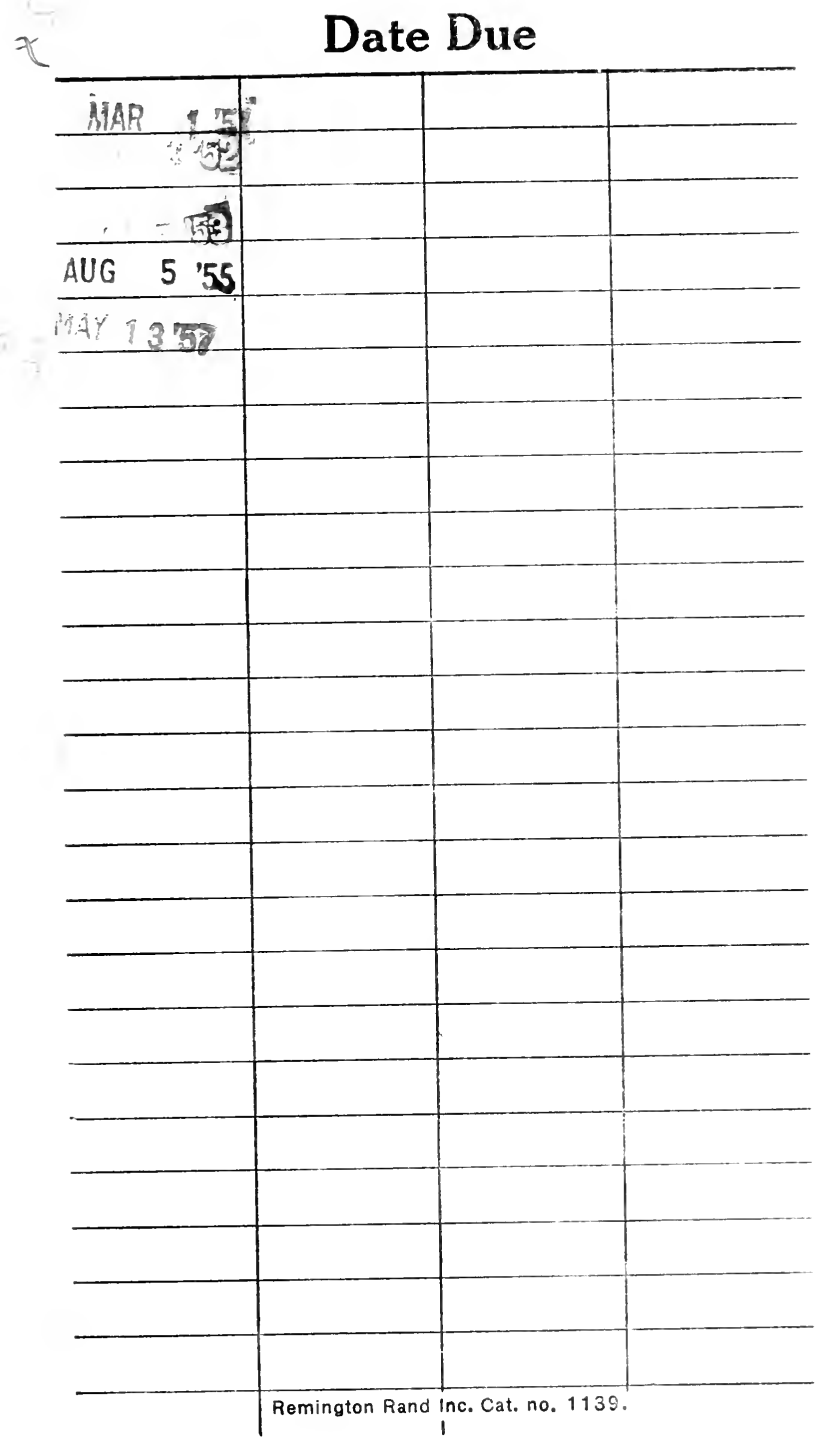





\section{A DEFENCE OF \\ CLASSICAL EDUCATION}




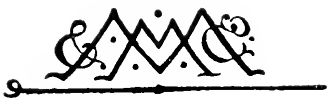

MACMILLAN AND CO., Limited

LONDON - BOMBAY - CALCUTTA - MADRAS

MELBOURNE

\section{THE MACMILLAN COMPANY}

NEW YORK - BOSTON - CHICAGO

DALlas - SAN FRANCISCO

THE MACMILLAN CO. OF CANADA, LTD. TORONTO 


\section{A DEFENCE OF}

\section{CLASSICAL EDUCATION}

BY

\section{R. W. LIVINGSTONE}

FELLOW AND ASSISTANT TLTOR OF CORPUS CHRISTI COLLEGE, OXFORD

MACMILLAN AND CO., LIMITED ST. MARTIN'S STREET, LONDON

I 9 I 7 
COPYRIGHT

First Edition 1916.

Reprinted 1917.

GLASGOW : PRINTED AT THE UNIVERSITY PRESS

BY ROBERT MACLEHOSE AND CO. LTD. 


\section{PREFACE}

This book owes much to the constant help of my wife; and I should also like to express my gratitude for suggestions and criticism to Dr. F. C. S. Schiller and Mr. A. E. Zimmern, who have read most of it in manuscript.

\section{PREFACE TO THE SECOND IMPRESSION}

ExCEPT for some corrections on points of detail, for which I am indebted to correspondents and reviewers, no changes have been made in this edition. I should like to take this opportunity of quoting a passage from $\mathrm{Mr}$. W. B. Yeats' "Reveries," to which Mr. F. W. Hall of St. John's College, Oxford, has called my attention. It is not only a notable tribute to the Classics, but also a just comment on the view that translations of Latin and Greek authors are adequate substitutes for the originals. Speaking of his father, he says (p. I09): "All he said was, I now believe, right, but he should have taken me away 


\section{PREFACE}

from school. He would have taught me nothing but Greek and Latin, and I would now be a properly educated man, and would not have to look in useless longing at books that have been, through the poor mechanism of translation, the builders of my soul, nor faced authority with the timidity born of excuse and evasion." 


\title{
CONTENTS
}

\author{
CHAPTER I \\ INTRODUCTION
}

I. Discontent with our educational system ; the classics

PAGE as scapegoats; yet the predominance of classical education in Germany shows that it is consistent with the highest scientific achievement . .

2. Some opinions on the value of classical education as a preparation for a scientific career . . .

3. Our real weakness lies in our natural indifference to knowledge . $\quad . \quad$. $\quad . \quad$.

4. This due (a) to the insufficiency of our secondary and university education in the past . . .

(b) to our university system doing little, in comparison with the German system, to foster the belief in knowledge. . . . . .

5. Object of this book . . . . . . .

\section{CHAPTER II}

\section{PHYSICAL SCIENCE AND THE HUMANITIES}

I. Two views of education criticised; (a) the ordinary business man's views on a 'practical' education.

(b) the extreme scientist's view; Sir Edward Schäfer on science as "the basis of secondary education': what physical science can and cannot teach us 
2. The function of the humanities in education :

PAGK

(a) They are an account of human nature, seen from different sides by literature, history and philosophy. How they assist us to a knowledge of Man

(b) They develop flexibility of mind . . 40

(c) They help us to see the world with imagination

3. This explains their place in education; physical science, though indispensable, cannot do their work, nor does it give a good general training to the faculties

\section{CHAPTER III}

THE CASE FOR THE CLASSICS: GREEK

I. The problem

2. Fallacy of the theory that classical education is a mere accidental survival from the Middle Ages.

3. We study Ancient Greece :

(a) as containing, with Rome, the history of our origins, and explaining much in our literature, language and ideals. . . . .

(b) for its literature, art and life; evidence of their value from $(\alpha)$ modern poets, $(\beta)$ the trenches, $(\gamma)$ the British Museum, $(\delta)$ the effect of Greece on the world at different epochs; meaning of Greek life to the Renaissance; its meaning to us; a modern working man on Greece

(c) as a pattern of creative intelligence; her achievement; Greek literature full of the key thoughts on which intellectual life depends: products of creative intelligence working on theology, literature, ethics, science; fallacy of the idea that Greek thought is antiquated, because the Greeks knew less than we 
4. Two illustrations of the Greek spirit :

(a) Socrates . . . . . . 106

(b) Hippocrates on epilepsy; his Physician's Oath

Summary; Greek literature as the Bible of the world of thought . . . . . .

I 2 I

\section{CHAPTER IV \\ THE CASE FOR LATIN}

I. Reasons for position of Latin in education less clear; in spite of a unique power of concise expression, its literature inferior to Greek . . . .

2. But Rome represents 'character' and thus supplements the weak side of Greece: her achievement.

3. Some typical Romans; Cato the Censor; significance and value of these characters

4. The Romans appeal to us (a) as more like us; Agricola: (b) as having done a similar work in the world; the interest of Roman history . . 147

\section{CHAPTER V \\ SOME EDUCATIONAL ADVANTAGES OF THE CLASSICS}

I. Can our own literature replace them ? . . I 5 t

2. Greek and English literature compared . . . 15;

3. Disadvantages of educating a nation on its own literature. . . . . . 162

4. Educational advantages of the classics:

(a) Their completeness . . . . . I65

(b) Their simplicity . . . . . 168

(c) Their natural lucidity and directness. . I 70 
5. The use of the classics (a) avoids the disadvantages PAGE involved in introducing boys to problems of life and politics through contemporary writers.

(b) gives independent standards by which to judge ourselves; Hazlitt's views . . . .

I 82

6. Greek as an introduction to modern problems :

(a) In history: a parallel between fourth century Athens and modern Europe . .

(b) In thought: the Sophists and Plato . . I9 I

(c) In politics: Greek criticisms of democracy; Plato and Aristotle as an introduction to politics; Aristotle on socialistic theories; Plato and the problem of industrialism . . . . .

\section{CHAPTER VI}

\section{THE CASE FOR GRAMMAR AND PROSE COMPOSITION}

I. How far can the classics be satisfactorily studied in translations?

2. Justification of the teaching of Greek and Latin grammar; their educational value . .

3. Justification of Proses: their value (a) as tests of intellectual ability, $(b)$ as developing concentration of mind, $(c)$ as a training in precision of language: practical uses of this training in life . . .

4. This accuracy cannot be learnt from (a) Physical Science or Mathematics, (b) nor, so well, from translation into modern languages . .

5. Summary of the arguments for classical education . 


\section{CONTENTS}

$\mathbf{x i}$

\section{CHAPTER VII}

\section{REFORMS}

I. The problem affects three classes:

PACE

(a) The problem of boys in the elementary stages

(b) Sixth form boys: present weaknesses in their teaching; these partly due to emphasis on scholarship in University Scholarship Examinations

(c) The Universities: weaknesses of Classical Moderations and University Scholarships at Oxford; excessive stress on pure scholarship.

2. Reforms : (a) reduction of composition in favour of Realien; (b) intelligent teaching of grammar.

3. The fundamental problem is to get good teachers and intelligent teaching. We need $(a)$ to be clearer what we can learn from the classics, $(b)$ to read more methodically and with more intelligence, $(c)$ to regard the classics as living things; instances of dead teaching . . . . .

4. Compulsory Greek; a suggestion for solving the problem. . . . . . . . $27 \mathbf{I}$ 



\section{CHAPTER I}

\section{INTRODUCTION}

THE war has indeed revealed grave shortcomings of detail in English education ....; but on the whole it has been a vindication of its essential soundness. It has proved us a nation not only sound and strong in character but far more adaptable, both in soldiering and in industry, than either we or our enemies suspected... . The grave defect of our national education is that there is not enough of it.

The Round Table, Sept. I9I6.

THE nation is discontented with itself and with its education. It is probably too discontented. Selfcriticism is a constant trait of the Anglo-Saxon, and his dark views of himself are always to be accepted with reserve. None of us would really exchange our governors, with all their vices, for those of any of the other belligerent countries, and this is a real, though unconscious testimonial to them. Nor could we in two years have created our present Ministry of Munitions, and have organised an army of four millions, if our science 
and education had been as bad as some people suppose. When the black fit passes, we shall take a more reasonable view of our deficiencies; still, no one would deny that they are there. What is the cause of them?

The classics are favourite scapegoats. And this view is the more odd, because it is one of the few which can certainly be disproved. It is very hard to assert anything definite in education, because of the great difficulty of knowing the precise effect on a boy of any particular branch of study. We teach our pupils, as doctors prescribe for many diseases, without any certainty as to the exact effects of the treatment; and education is an even less exact science than medicine. But in denying that the classics are responsible for our 'want of science,' we are for once on absolutely certain ground; for here we have definite facts to go upon.

Whatever faults the Germans have, nobody denies that they are a 'scientific nation' $;$ ' this quality of theirs is continually held up to our admiration, and it is implied that they have become

${ }^{1}$ A critic has warned me that to quote Germany is to prejudice my case; but such persons as are likely to read this book will be able to judge dispassionately, even in present circumstances, of what is good and what is bad in German 


\section{INTRODUCTION}

'scientific' by giving physical science a predominant place in their higher education. Nothing could be further from the truth. On the contrary their secondary education is far more classical than ours, and they have far more compulsory Greek and Latin. Let me briefly review the development of their secondary schools since 1870 . Before that date it was impossible to enter a German University, except through the classical gymnasium, which exacts a high standard in Greek and Latin; but in I870 it became possible for students from the purely modern Realschulen to proceed to the University if they wished to study Mathematics, Natural Science or Modern Languages. Students of all other subjects were still under the yoke of compulsory Greek or Latin. This yoke was removed in I90I from all, except students of medicine, who must know Latin, and theologians, who must know Latin and Greek.

Now there are three points to be noted here:

(I) The makers of the greatness of modern Germany are the generations educated before

education. Here I have only to deal with its power to produce certain intellectual qualities, and not with those features of it which stifle independence of political opinion and stimulate a maniacal nationalism. 
I 900 ; the vast majority of these were educated in the classical gymnasium with its compulsory Latin and Greek.

(2) Even in I9II, of over 400,000 boys receiving secondary education in Germany, 240,000 were at schools in which Latin is compulsory, and 170,000 of these at schools where Greek is compulsory also.

(3) In the remaining, purely 'modern,' Realschulen, so far from physical science occupying the chief place in the curriculum, only two hours out of twenty-five per week are allotted to it in the lowest forms and six out of thirty-one in the highest.

The moral of these facts is that the highest scientific eminence can be attained by a nation in whose secondary education physical science is subordinate. They prove with absolute conclusiveness that a classical education is not in itself the obstacle which prevents our becoming a 'scientific' nation. It is surely not too much to ask that our critics of the classics should attend to these figures, especially if they criticise in the name of science. In their own subjects they would consider it a duty to collect and weigh all the available facts before they arrive at a con- 


\section{INTRODUCTION}

clusion. They are not exempted from doing so, when they come to talk about education; but if anyone reads the Report of the Conference at Burlington House, he will find no trace that these elementary and accessible facts had ever been considered by the speakers who attacked the classics. Yet they are very instructive. They do not prove that all boys should learn Latin and Greek, or that modern schools are unnecessary, or that physical science can be ignored, or that everything is for the best as it is ; but they do prove that a nation can be 'scientific,' though compulsory classics are the staple of its secondary education, and though the majority of its youth is trained in classical schools.

It is generally assumed by the critics of the classics that they are at any rate useless to the future scientist. Here again it is interesting to glance at Germany; not that German education is perfect, but that it exhibits the results of experiments that bear on our present dispute. In I870, as we saw, the universities became partly open to students who did not know Latin and Greek. In I 880 , after ten years of trial of the new system, a manifesto was addressed to the Prussian Minister of Education by all the members of the Philo- 
sophical Faculty of Berlin University ; it records the opinion of the results of the change which was entertained by the most eminent teachers and savants of Germany. It should be remembered that the Philosophical Faculty in Germany includes Mathematics and Physical Science; the manifesto was thus signed not only by historians like Mommsen, Droysen and Curtius, philosophers like Zeller, and scholars like Vahlen and Nitsch, but also by the leading men of science in Germany, among them men of world-wide reputation like A. W. Hofmann (chemistry), Helmholtz (physics), Kiepert (geography), and by many other scientists. Here are some extracts: "It is also emphasised by the instructors of chemistry that graduates of Realschulen (Modern Schools) do not stand upon the same level with graduates of Gymnasia (Classical Schools). Professor Hofmann observes that the students from Realschulen, in consequence of their being conversant with a large number of facts, outrank, as a rule, those from the Gymnasia during the experimental exercises of the first half-year, but that the situation is soon reversed, and, given equal abilities, the latter almost invariably carry off the honours in the end ; that the latter are mentally better trained, and 
have acquired in a higher degree the ability to understand and solve scientific problems. Professor Hofmann adds... that Liebig expressed himself at various times to the same effect." ' Similar testimony is given by the professors of Mathematics, Zoology, Modern Languages, Economics and Statistics. Professor Hof mann's own opinion is given elsewhere, "that all efforts to find a substitute for the Classical Languages, whether in Mathematics, in the Modern Languages, or in the Natural Sciences, have been hitherto unsuccessful, that after long and vain search, we must always come back finally to the result of centuries of experience, that the surest instrument which can be used in training the mind of youth is given us in the study of the languages, the literature, and the works of art of classical antiquity." 2 This testimony is the more striking, because it is not mere dogmatising without experience by men who might be supposed to have a personal prejudice in favour of the classics. It is the considered opinion of all the science and mathematical professors in

${ }^{1}$ Inaugural Address delivered by A. W. Hofmann on Oct. I 5 , I 880 , with appendix, translation published by Ginn \& Heath, Boston, I883, p. +9 .

IIb. p. vii. 
the chief university of Germany, after ten years' trial of the 'modern' schools. Similar views were expressed in 1897 by the professors of the Technical High School at Karlsruhe, who declared that "the systematic study of Latin as a school discipline was of the highest value for engineers, botanists, zoologists, mineralogists, chemists and physicists. The memorialists indeed advocate the study both of Greek and Latin at schools, in the case of a boy intending to follow any of the above scientific pursuits, but of the two ancient languages, they emphasise Latin as the more indispensable." There again we have a considered opinion of scientific specialists, with no axe to grind, and with experience of the results of both classical and modern education. ${ }^{1}$

${ }^{1}$ Dr. M. Sadler, Problems in Prussian Secondary Education (Board of Education Special Reports, vol. 3, p. 2 I 8). In the same place is quoted the interesting protest by the late M. Jaurès in favour of classical education. "He spoke against giving equal recognition to the classical and modern sides in secondary schools on the ground that, in the headlong competitive struggle of the present time, the sterner mental discipline afforded by Latin and Greek will give way before what Americans call 'soft options' in school curricula, unless a premium is set on the former. He pleaded for the preservation of classical studies... as a memento of disinterested culture. Otherwise even the field of education would be submerged under the rising tide of commercialism." 
The facts and opinions just cited should keep us from the dangerous mistake of supposing that we are simply suffering from the predominant position of classics in our public schools, and that we have only to expel them in favour of physical science and modern languages, to be cured of all our ills. This idea, which was fostered by the Science Manifesto last February, seems to be losing ground, and it is well that it should, for if we base our reforms on it, we shall be like doctors who mistake a minor symptom for the real disease. It is no doubt true that we need more physical science in industry and elsewhere; but that is only a symptom of a more serious weakness. What is really wrong with us is that as a nation we do not believe in knowledge.

The slowness of some of our manufacturers to use science in industry is one sign of this. But there are other and much more serious signs. If an account is ever published of the work done by a certain section of the Admiralty Intelligence Department since the war began, we shall have plenty of evidence of our indifference to knowledge in departments as important as industry. Under the pressure of the war a branch of that Department has been amassing ethnographical 
and geographical information, which we now find essential, and which we have hitherto neglected to collect. ${ }^{1}$ It might have been supposed that a great empire would have had some kind of a Civil General Staff, which would collect such facts, and pigeonhole them for the time when they should be needed, instead of having to improvise hurriedly a practically new Department, and ransack French, Dutch and German periodicals and books for knowledge which bears directly on its deepest interests. But though we have great geographers and explorers, we have never used their services methodically, or thought it necessary to accumulate and store the facts in which they deal, as we accumulate and store munitions or anything else necessary to the conduct of war. That is a sufficiently serious symptom of our national indifference to knowledge. Obviously it does not spring from ignorance of physical science, nor is it to be cured by instituting a preliminary science examination in our universities.

We generally regard this comparative indifference to knowledge as a quality of our breed, as

1 The branch in question is a new and extraneous development of the Admiralty Intelligence Department, which, no doubt, in its own work has from the first been efficient and prepared. 
natural as the blue eyes and light hair of a Northman, and, resigning ourselves to being less thorough than the Germans, hope to make up this deficiency by other qualities which they do not possess. But our weakness is surely nothing mysterious. It is neither an ineradicable strain in our blood, nor a consequence of too little physical science in our education. It is the natural result of insufficient education of any kind. "In Prussia," wrote Mr. Sadler in 1899, "the machinery for the organisation of secondary education has been at work for more than seventy years. In England it is still, both locally and centrally, incomplete." And again: "There is little doubt that, so far as wide range of all-round intellectual attainment goes, a higher average is reached in the average German secondary school than is the case with us. There secondary schools of high quality are more uniformly spread over the whole country than is the case in England. 'They are cheaper and more accessible to poorer families of the middle class." 1 In fact, a smaller public is educated in England than in Germany, and, as a whole, it is less well-educated. It is the same with university education. There are twenty-one universities in 
Germany, of which the latest was founded in 1826 . There are eighteen in Great Britain, but of these seven have been founded since 1900 (the University of Wales was founded in I893), and only six were in existence in $1830 .^{1}$ Consequently in Germany a much larger proportion of the population has had a university education than in England, and, it is not surprising, if the Germans, having had more education, and knowing better its value, prize knowledge and use it more than we do. ${ }^{2}$

${ }^{1}$ It is characteristic that Scotland, the most intelligent part of Great Britain, possessed four of these.

The significance of these figures can only be appreciated, if we remember that the full effect on a nation of any improvement in its educational system is not felt for at least 20 years after it has been introduced.

2 According to the Statesman's Year-Book the statistics of university education work out as follows :

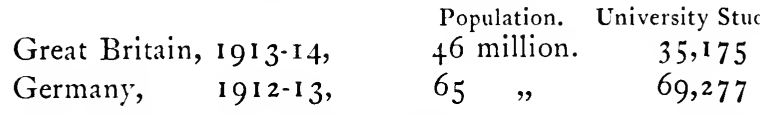

These figures need further analysis; for Britain, they include in some cases evening students and undergraduates who have finished their studies, but have not taken a degree; for Germany, they include nearly 10,000 unmatriculated students, but take no account of over 16,000 students at technical high schools with power to grant degrees. And examination might reveal other discrepancies.

There are obviously many other imperfections in our education contributing to the same result, which are not mentioned here. 


\section{INTRODUCTION}

If this is the real cause of our weakness, matters are not so unsatisfactory. We have simply to improve our secondary and university education, and to extend them further among the population. This has been done of recent years-since $\mathrm{Mr}$. Sadler wrote, great changes for the better have been made in our secondary education, and seven new universities have been provided-and if we continue on these lines, knowledge, and with knowledge, the belief in it, will grow. The new generations will value it more, and apply it more in all departments of life, and we shall become a 'scientific' nation, not in the sense that our education is largely in physical science, but that, whatever we do, we shall realise that the first business is to collect the relevant facts, so that we can base our action on knowledge. And this is the kind of science we really need. The Germans possess it, not because they have more physical science and less classics in their schools, but because they have more education generally. They have used the fertilizer of education widely, and the resulting crops are better than those of nations that have used it less.

There is something, too, in the nature of the particular fertilizer, at any rate in the case of the 
universities, which explains how the search for knowledge has become a second nature with the German. Consider the difference between study at a German and at an English university. At the former the student breaks completely with school life and the curriculum of school; when he leaves his Gymnasium or Realschule, he is supposed to have received the 'general culture' which is the basis of any sound education, and in his university career he is to learn the means by which knowledge is advanced, and himself to take some part in advancing it. For his degree he must write a thesis, which is a bit of original research, a piece of work that has never been done before, that cannot be derived from text-books, and that involves independent enquiry. 'The atmosphere is favourable. For a German university is a great workshop of research; everyone is researching in his own particular subject, whether it is law or chemistry or Americanismus; and the professor, having no private pupils, simply lectures some six or eight hours a week, and for the rest of his time devotes himself to advancing knowledge in whatever branch he has chosen. It is easy to see the effect of this atmosphere and this education on the student. He gets possessed-sometimes obsessed 
-with the idea of research, of original work, of advancing knowledge. He learns how to do this in his own subject. He goes out into his profession a qualified, and generally an eager, enquirer ; and we find him as a chemist in the Badische Anilin Fabrik researching into the quality of dyes, as a doctor writing a thesis on some minute question of pathology, as a civil servant enquiring into the causes and prevalence of tuberculosis in the cows of East Prussia, as a scholar investigating the authenticity of a treatise of Plutarch. The particular work varies; it is often trivial, often bad; but there is more of the spirit of research, that is, of the spirit of science, in Germany than in any other country. And it springs from the method of study followed at German universities.

Now consider the atmosphere of an English university. We have always taken the view (rightly I think) that an undergraduate is not sufficiently educated to research; so with us university work is really an extension of school work, more advanced, but essentially the same in that it involves no original investigations. There are the proses and essays of school in a more difficult form, and a rather haphazard examination of original authorities; but there is nothing like 
the thesis which admits the German to his degree. Nor is the surrounding atmosphere one of research. The college tutor cannot, like the German professor, retire at 9 a.m., his lectures for the day done, to devote himself to the advancement of learning. He probably spends twenty-four hours in the week in that most exhausting of occupations, teaching, and though college tutors do original work even under these conditions, from the nature of things it generally lies outside their tutorial instruction, which follows the course prescribed for examinations. Under a university system like this is produced a type more balanced, and in a sense, better educated than the Germana type acute and critical, with a good general culture, and with a fairly wide basis of knowledge, and a capacity for handling it and putting it on paper which Germans rarely possess; its weaknesses are an over-critical mind and a tendency to consider that knowledge consists in getting hold of half-a-dozen salient facts and presenting them skilfully in an essay-the student has done this so often with his tutor that he cannot believe that anything else is required. A succession of essays and examination questions has never brought him into contact with that 'method of science,' which 
belongs to historical and literary research as much as to chemistry or physics, and he generally leaves the university without the idea of advancing knowledge ever having occurred to him. Such a type is common in England, and can be easily recognised on the Government Front Bench. It has many virtues, but it is not a type that naturally believes in knowledge or pursues it as Germans pursue it ; and its prevalence explains, for instance, why the Admiralty Intelligence Department found so much information ungathered at the beginning of the war, and why the Government, as Professor Poulton complains, often acts on its own ignorance instead of realising that it ought to consult experts.

It is not easy to change this. The German thesis system, in its unmixed form, has many evils, and more is seen of them than of its virtues when it is transplanted to foreign soil. ${ }^{1}$ Yet the introduction of some real research work into our degree course would counteract its present tendencies. We have too little research at present, while the Germans have too much; and the recent reform in the Oxford Chemistry School, by which a piece

${ }^{1}$ See an account of the working of the thesis system in America in Mr. S. Leacock's Essays and Literary Studies, p. 63 fi. 
of original work is necessary for high honours, is more likely than any other change hitherto proposed to make for the advancement of 'science' in every sense of that word. The Government might do something if they encouraged Indian civilians to do some suitable research during their 'long leave,' instead of spending their time in travelling or tennis ; many Nigerian civil servants do at present take diplomas in anthropology during their leave, and their example might be imitated, mutatis mutandis, in other branches of the public service.

These are big subjects on which to touch cursorily: but it was necessary to allude to them, because the root problem is: what is wrong with us, and in what way is our education at fault? I have tried to shew how superficial it is to suppose that our one defect is ignorance of physical science, and that we have only to remedy this, and to abolish what some critics like to call our ' mediaeval system' of education. Our disease goes deeper, and the neglect of science by some manufacturers is only a symptom of it. Practical experience, as we have just seen, shews beyond the least possible chance of doubt, that classical education, however compulsory and widely extended in a nation, is 
perfectly consistent with that nation being highly 'scientific'; and, as we have also seen, many men of science consider that the classics are a better preparation for a scientific career than is a 'modern' curriculum.

Now, passing from facts to theory, I wish to ask on what qualities are based the claim of Latin and Greek to a place in education, and what are the virtues which have made great scientists prefer their training to that of ' modern' subjects. In doing so I shall try to meet the stock objections that they are not 'modern' (p. I $86 \mathrm{f}$.), that the ancients, being far more ignorant of science than we, are not worth study (p. IoI f.), that it is absurd for those boys to learn Latin, who will never learn to read it fluently (c. 5), that modern languages can take the place of Latin and Greek (c. 4 and c. 5). To guard myself against certain criticisms, I would say that nothing in this book is inconsistent with a belief that everyone ought to know some science, that we need more science in national life, that a narrow classical specialism (like all narrow specialism) is bad, that a classical education does not fully meet the needs, or suit the capacities, of every boy, and that the teaching of classics 
needs continual improvement-in which point it resembles the teaching of all subjects. ${ }^{1}$

1 Nothing would be more useful than for competent and experienced teachers of science to put forward their views on a satisfactory science curriculum, stating what branches of science they thought suitable to boys at what ages, and how they should be taught. Laboratory work with big classes is for most boy's a pleasant, but otherwise unprofitable, way of wasting time; and it is difficult not to feel that sciences like physics and chemistry, where it is essential to grasp abstract laws, are far less suitable for the concrete mind of a boy than geology or perhaps physiology. It would be a great improvement if some science could be included, possibly as an alternative subject to philosophy or to ancient history, in the Oxford Greats School; philosophy and science illuminate each other, and such a change would give a chance for clever boys, whose interest in science developed late, to take it up properly. Whatever changes are made, it is to be hoped that science will not be given a preferential place in the Civil Service examination. That it is not unfairly treated, is shewn by science men occupying the first and third places in the list in 1913, and the second place in I9I4. But it would be disastrous for the nation, and very inconvenient for business men, if our young scientists were tempted away from commerce, research and teaching into a place for which their training was not designed, and where their peculiar gifts were only occasionally exercised. The Civil Service, with its security, its pension and its excellent salary, already absorbs talent which might often be better used elsewhere; and if it took the ablest young men of science, the nation certainly would not gain. 


\section{CHAPTER II}

\section{PHYSICAL SCIENCE AND THE HUMANITIES}

$\mathrm{T}_{\mathrm{HE}}$ aim and office of instruction ... is to enable a man to know himself and the world. $\mathrm{M}_{\text {ATtHFW ARNOLD. }}$

THE study of letters is the study of the operation of human force, of human freedom and activity; the study of nature is the study of non-human forces, of human limitation and passivity.

Id.

WE are going to ask why the modern world studies the classical literatures. But some one may raise the previous question: Why study literature at all? This question is often asked in letters written to the papers by indignant fathers, who want to know why their sons, destined for business, learn fancy subjects instead of things serviceable to them in after-life. They expect their sons to pick up certain knowledge at school, and are disappointed if they confuse Alexandria with Alexandretta, do not know what ice-free ports Russia has, fail to 
supplement the parental knowledge of history, or make fools of themselves by some obvious ignorance. They are always rather disappointed because the amount of knowledge gathered at school is small, because there is 'so little to show' for the years in the class-room, and-the standing grievance-because very few boys acquire modern languages during them. What, they ask, is the good of an education which doesn't even teach French and German properly?

There is something in these complaints; boys might be taught geography and physical science and modern languages better, though few will learn at school to talk fluent French and German. But no one would suffer more than the complainants if they were allowed to impose on us the curriculum of their dreams. I say nothing of the effects on a boy's character of training him for the business of money making, and making this from the outset the object of his efforts. Horace noted such a habit in the Roman parent, and its effect on the boy:

Our Roman boys, by puzzling days and nights, Bring down a shilling to a hundred mites. Come, young Albinus, tell us, if you take A penny from a sixpence, what 'twill make. 
Fivepence; good boy! you'll come to wealth some day. Now add a penny. Sevenpence he will say.

$\mathrm{O}$ how this cankering rust, this greed of gain, Has touched the soul and wrought into its grain ...1 But apart from the results of a deliberately cultivated materialism, the business man would soon find out that an education may impart all the knowledge in the world, that its victims may be walking dictionaries, but that it fails, or is successful by the qualities it develops in its pupils and not by the knowledge it puts into them. Lord Morley says somewhere: "An educated man is one who knows when a thing is proved and when it is not. An uneducated man does not know." This is a partial definition of education, yet the educational reformer will do well continually to remember it. It may be inconvenient to be unable to place Alexandretta, but not to know when a thing is proved-that is a real disaster. To be unable to sift the evidence, to confuse the essential facts with unimportant details, to miss the bearing of a point, to be deluded by sentiment or passion or rhetoric or humbug, whether it be in politics, education, business or private life, means failure, as its opposite means success.

${ }^{1}$ Ars Poctica, $325, \mathrm{tr}$. Conington. (I have slightly altered the last line but one.) 


\section{4

Some of our critics speak as if a boy came into a schoolmaster's hands as steel comes into the hands of a machine-tool maker, ready, without further preparation, to be manufactured, and then let loose complete on the world. They forget that a boy of fourteen is raw material, and must undergo many processes before he is fit to take his final shape. No one would propose to make high pressure steel out of the crude ore as it leaves the mine; if he got any resulting metal from such an attempt, it would be coarse and brittle. But an attempt to run human raw material into its final mould before it has been refined and tempered will produce something equally unserviceable. The crude ore comes to the schoolmaster wanting in bite and cutting power, unable to stand a sudden strain; his essential business is to turn the rude metal into high pressure steel, and on the success of the endeavour will depend, other things being equal, its serviceableness and effect in after-life. The knowledge may be picked up later, but the training of the mind never. Hence so much that seems needless and annoying in education. It must impart qualities and powers essential if its product is to be useful, but of which that product has, as yet, hardly a trace. Accuracy, concentration, sym- 
pathy, judgment are obvious needs, but not less necessary is the revelation of the world itself. Education, it has been said, should knock windows into the world for us. We are born into a closed and darkened room: as the windows are opened, we see, here, man, with all his character and capacities, experiments, endless achievements and possibilities; there, the material world itself, the elements that compose, and unexpected laws that govern it. The windows are unmade, or in the making, when we are fourteen; we have no notion of the landscapes and moving figures outside our prison-house, and an essential of education is to make openings in its walls, and take us to them, and give us time to view the scene beyond.

That explains why the school time-tables are not filled with colloquial French or book-keeping. Taking a wider view of what is necessary to success in life-to put the lowest motive-education remembers that the power to understand other points of view, to 'know when a thing is proved and when it is not,' to realise the various possibilities, material and human, of the universe, is even more necessary to the business man than a knowledge of French or commercial geography.

An open and alert mind, which understands 
human nature and its possibilities, which can judge and sympathise, which because of its wide survey and outlook on the world creates new opportunities and developments, prospers in commerce or in any work; but it is the child of a varied education, not of narrow technical training. So education, remembering this, says to the complaining parent: Your boy will get his commercial and professional knowledge ; but it is my first task to give him a general training, to open windows on the world, and thus give him a glimpse of its possibilities, and a sense of proportion. Commerce will not flourish the better if I send into it men of narrow outlook and untrained minds; and in the end, my method will pay you, even in mere coin of the realm.

If a College tutor, with no special knowledge of commerce, were to expound his ideas on running a big business, his shots would go wide; amateur suggestions on education are apt to be equally ill aimed. Education is a profession which requires at least as much thought and experience as any branch of commerce; and it would be unfair to use such views as men of straw, convenient and easy to demolish. Instead, let me take the case against literature, as it might be put by a man of 
science, who was extreme in his views, but prudent and capable in expressing them. He would condemn the notion of giving the first place in education to literature, history and philosophy (as do our older universities). "It is a first necessity," he would argue, "for us, as a people, to comprehend the paramount part which science must occupy in genuine education if Great Britain is to maintain her position in the world. This position actually depends not on military power, important as this may be for the defence of the country, but upon the fact that we are, after all, as Adam Smith reminded us, a nation of shopkeepers, and that the goods we have to dispose of are no longer made by rule of thumb, but by the application of physical and chemical principles to the processes employed in their production. It is therefore obviously desirable that a knowledge of those principles should be diffused throughout the community." 1 Even for boys who are not going into business the same is true. 'Do you really maintain,' we are asked, ' that the dead world should be studied before boys know the living world around them? Literature and philosophy are luxuries, but for the hard, practical business of life, a man

${ }^{1}$ Sir E. Schäfer, Times Educational Supplement, March $;,$ i 916. 
must understand the things among which he moves every day. Is he to remain ignorant of the nature and history of the soil on which he lives and from which his wealth comes; or of his body, of the laws which govern its health, of the methods in which its food is digested, or in which its nerves, flesh and bones are compacted; of the principles of mechanics which not merely control the great mechanical inventions that feed, clothe and transport him, but without which he would be actually unable to move his limbs? He must spend all his life in the presence of these realities; in his education alone shall he walk in the shadow world of literature? Science covers the greater part of life, let it cover the greater part of education also.' "What is actually wanted is that instruction in science shall form the basis of secondary education, and shall even share with the three R's the time allotted to elementary instruction." I That, I hope, is not an unfair statement of the extreme scientific case ; some of it is taken from a letter by a well-known man of science.

Now let us examine it a little closer. It is true that without physical science our whole civilisation would collapse ; and it is a just conclusion from ${ }^{1}$ Sir E. Schäfer, l.c. 


\section{THE HUMANITIES}

this that the community must contain a sufficient number of trained men of science to meet its needs. But it is not a just conclusion that every citizen must be a trained scientist. The community would equally collapse if it had no farmers, no shipwrights, no teachers - the list may be extended indefinitely; but it is not a just conclusion from this that we must all study agriculture, naval architecture and pedagogics. Because specialists are necessary in all branches of life, it does not follow that we must all specialise in every form of specialisation. Why is physical science to be given an exceptionally favoured position?

The reply made is, because physical science covers the greater part of life. But does it? Take this present war and ask how much of it physical science explains. What does it tell about the causes of the war? Nothing; you must look for them in the past history of Germany since Frederick the Great, in German thinkers, Nietzsche, Treitschke, and a host of others, in political and moral philosophies, in theories of empire, and nationality, in Russia, Austria, the Balkan States, in the wealth of the Turkish empire and the nature of its government and inhabitants, in the character of the various peoples fighting-an 
enquiry which takes us infinitely far before we find the forces which have moulded national spirit and temper, and made Germans, Frenchmen, Russians, Britons so strangely different. Physical science covers only the tiniest plot of all this ground; all it could tell us about the war is something about coveted mineral deposits, something (very little) about industrial complications, and practically everything about the material means by which the war is being fought. This knowledge is, no doubt, indispensable, but it covers neither the whole, nor even the greater part of the war, any more than it covers the whole or the greater part of life.

The great gap in science is that it tells us hardly anything about man. This sounds paradoxical; yet consider. Suppose that we have studied physics, chemistry, physiology, zoology and the rest, how much do we thereby know of man? Perhaps we have mastered the history of his tissues, his nervous system, his bones and sinews; perhaps we understand his structure and constitution, the laws which regulate his production, growth and decay. Still, we know nothing of him as he moves in actual life. The man who is our friend, enemy, kinsman, partner, colleague, with 
whom we live and do business, who governs or is governed by us, has never once come within our view.

That is why it is impossible to 'base our education on physical science.' It omits a branch of knowledge which everyone needs. It is possible for the ordinary man to dispense with a knowledge of physical science; he can go to specialists who will do his business for him better than he can do it for himself. Considering that the world reposes on physical science, it is wonderful how well most of us can get along without any knowledge of it, provided our occupation does not demand actual scientific knowledge. (The layman, in spite of his ignorance of physiology, enjoys no worse health than a doctor.) But no one can dispense with a knowledge of man. Everyone needs it, and is using it each minute he is in relation with human beings, whether he is speaking to them, or reading what they have written, or engaged in work which at any point touches them. We need this knowledge as private individuals: and still more, we need it as citizens and voters; the political conditions of England make it absolutely indispensable for us. Our need of science may be great, but our need of political 
and moral wisdom is greater, not less obvious, more difficult to remedy, and more dangerous to the state. We may require more chemists, and need to appreciate and employ them more than we do, but the storms that loom above us and threaten to break in most disastrous ruin are political ; they are the dangers of a self-willed, impetuous and ignorant democracy (and by democracy we do not only mean the labouring classes). This democracy is called to vote on problems of government at home and abroad, to decide between the policies presented to it, to discern whether truth resides in the glib tongues of its leaders and the facile pens of its daily papers. Without some knowledge of itself, and its neighbours in the world, of the ideals that sway or have swayed its own and other countries, of the judgments that history records on the experiments, crimes and blunders of past ages, the steps of humanity will be more blind and blundering than ever. Metallurgical or chemical analysis needs highly trained skill and knowledge ; but the analysis of political and moral problems is at least as complicated and urgent, and it is work which cannot be handed over entirely to experts; if we do not all take some share in it, we are all, as voters, called to pronounce a decision upon it. If 
a voter knows nothing of trinitrotoluene, England will not be much the worse for his ignorance; but she is in a bad case, if her citizens, however primed with physical science, cannot appreciate and judge the political issues at stake. The attitude of some sections of our population at the beginning of this war should have convinced the most sceptical that the ignorance of a democracy is a real danger. Now this knowledge cannot be acquired merely by living in the world. It is in books. Physical science cannot give it ; for it is the knowledge of man recorded in history, and, more vaguely, in literature.

What, more precisely, do we get from the studies on which our higher education is at present based, the studies which some critics wish to replace by more 'paying subjects,' and which Sir E. Schäfer wishes to replace by physical science? There is no good English word to describe them ; but for convenience' sake we will call them the humanities, a term coined at the Renaissance. How do we justify their prominence in education?

First, as science reveals to us the physical constitution of ourselves and of the world round us, 
so the humanities reveal to us man. There is no science of man; anatomy and biology, while they have much to say about his body, throw little light upon his behaviour, nor explain why he makes a French Revolution or a European war, why he is a miser or a spendthrift, a Machiavelli or a Frederick the Great. Physical science does not deal with this kind of thing. Yet the "science" which everyone needs, and statesmen above all, is such a knowledge of man.

Now there is, if not a science, yet a record and account of man; we call it, according to its various aspects, by the various names of literature, history, philosophy. And this is the justification of the literary-philosophic-historical education which prevails in our secondary schools and universities. Generally speaking, the subject of that education is man; man viewed in himself and his proper nature, viewed as literature views him, as a being with feelings and prejudices, virtues and vices, ruled by intellect, or perverted by passion, inspired by ideals, torn by desires, acting on plan and calculation, or carried away by unreflecting emotion, sacrificing his life, now for gold, now for an ideal-an adulterer, a patriot, a glutton, a dreamer, Aegisthus, Oedipus, Hamlet, 
Macbeth, Faust-; or man, viewed as a being governed by the laws of a universe outside him, viewed as philosophy views him, subject to limitations of time and space, of his own origin, nature and destiny, related to beings and forces outside him, adapting himself to those relations and modifying his action according to his conception of them, a creature with moral capacities or the descendant of an ape, determining his future according to his wishes, or merely one wheel among many blindly revolving in a great machine : or thirdly, man, viewed as a political and social being, as history views him, creating states and overthrowing them, making laws and refusing to be bound by them, opposing religion to politics, and freedom to law, binding art and politics, empire and freedom, public and private life into a harmonious whole, or crowning one to the exclusion of the rest, fighting, colonising, making money and spending it, treating his neighbour as a fellowbeing, or using him as a tool for the production of wealth, monarchist, parliamentarian, socialist, anarchist, Pericles or Augustus, Cromwell or Robespierre. Before the student of literature, philosophy and history are displayed all the forces and ideas that have governed man, personal, 
religious or political ; to see why he has rejected this and espoused that, why this failed and that was successful, what are liberty and religion, family affection and personal greed, and in a word, to study Man. As he reviews them, and compares them with the present, he can see, as far as a man can see, what ideas have come down to his own day, and what new elements are combining with them, can forecast in some degree the future, and by virtue of his knowledge guide the streaming forces, and shape the molten mass, serve his country and use to the best advantage his own powers. ${ }^{1}$

If anyone thinks this pedantic, and believes that the knowledge of man is only got from life, let him read Anna Karenina or The Ordeal of Richard Feverel, and say if he learns nothing from them about marriage, education and human nature in general; and let him remember the opinion of a man who knew the world and was not a pedant. Lord Chesterfield wrote to his son : the knowledge of the world and that of books " assist one another reciprocally; and no man will have either perfectly, who has not both. The knowledge of the world is only to be acquired in the world, and not in a

${ }^{1}$ I have quoted this passage from an article of my own in the first number of the Oxford and Cambridge Review. 
closet. Books alone will never teach it you ; but they will suggest many things to your observation, which might otherwise escape you ; and your own observations upon mankind, when compared with those which you will find in books, will help you to fix the true point." That is perfectly true. The world is far more intelligible to us if we have studied history and literature. We understand Hamlet or Brutus, when we meet them in the flesh, far more readily if we have already met them in Shakespeare. Their actions have a meaning for us because we have the clue to their character. We are like visitors to a foreign town who have already studied its map; the lie of the land, the plan of the whole is already familiar for us, and we pick up our bearings quickly, instead of wandering vaguely about the streets.

Consider what a literary education in theory is, and in fact might easily become. The student of literature moves familiarly in an infinitely vast and varied assembly. Even if he confines himself narrowly to the classics, he meets there all sorts and conditions of men-neurotics as different as Lucretius and Propertius, conservatives as different as Pindar and Aristophanes; he meets the man of letters as politician in Isocrates and Cicero, and the 
politician as man of letters in Caesar; he learns to know worldly commonsense incarnate in Horace, reason incarnate in Socrates; he sees the pessimists of an over-civilised society-Juvenal, the disappointed bourgeois, Tacitus, the soured aristocrat, Marcus Aurelius, the disillusioned saint; he notes how differently Plato, the imaginative idealist, and Aristotle, the clear-sighted analyst, prescribe for their distempered age. These are only a few of the types whom he learns to know as intimate friends, whose dispositions become familiar to him, into whose moods and personality he can in a moment throw himself. And I have said nothing of the characters they have painted in their books.

The value of history is even more obvious. The nation might have been saved something by a little knowledge of German history ; and a study of the Napoleonic wars might have preserved us, if not from certain strategical mistakes, yet from our worst fits of despondency about ourselves and our rulers: while one great danger, as we set about social reform, is that the democracy knows very little history. Yet even so, we have learnt immensely from history, and our whole political attitude, consciously or unconsciously, is coloured 
by our knowledge of it. ${ }^{1}$ One point in which we differ most profoundly from the Greeks and Romans, in other ways so like us, is that we have more history behind us, and have learnt more from it. It is history that has taught us the lesson of political toleration; it is history that gave a constitution to South Africa, and is giving a parliament to Ireland.

If history needs no apology, philosophy needs a good deal. Its name is against it; and we forget that when we think, argue or act, it stands behind us, the unseen framework of all our practice, which becomes visible as soon as we ask how or why. Bishop Berkeley's grave and measured saying is its best justification: "Whatever the world thinks, he who hath not much meditated upon God, the human mind, and the Summum Bonum, may possibly make a thriving earthworm, but will certainly make a sorry patriot and a sorry statesman." 2 "

It is as the study of man that the humanities claim their predominant place in education, and in this age of material things, while we honour science

${ }^{1} \mathrm{~A}$ boy must be very badly taught if he studies the Civil War without modifying some of his views; to understand Cromwell, Strafford and Laud is a political education.

${ }^{2}$ Siris, $\$ 350$. 
and pay her dues, we shall do well sometimes to remind ourselves that man is more important than nature, and man's spiritual, more important than his physical, constitution. Philosophically it may be disputable, practically it is admitted, that the world exists for him; and those who deny it with their lips assert it by their actions and their attitude to life. "Quand l'univers l'écraserait, l'homme serait encore plus noble que ce qui le tue." "Social progress means a checking of the cosmic process at every step and the substitution for it of . . the ethical process." I Pascal and Huxley are here agreed. We cannot in our education give the chief place to the junior partner.

Then a further point. One of the chief objects of education is to train flexibility of mind, to make a man quick to comprehend other points of view than his own. Obviously, no power is more necessary in dealing with men. To be able to discard for the moment his own opinions, and see the world through the eyes of other classes, races or types, is as indispensable to the merchant as to the statesman; for men are hardly to be controlled or influenced unless they are understood. And yet

${ }^{1}$ Huxley, Evolution and Ethics (Eversley edition), p. 81. 
no power is rarer. It is almost non-existent among uneducated people. A man who has not risen above the elementary school, is hardly ever able to seize an attitude of mind at all different to his own; he may acquiesce in it because he trusts or respects the character of the person in question, but he does not understand it ; he cannot perform the great feat for which our intellectual gymnasia train us, of being in two (or more) people's skins at the same time. And this is not due to the absence of any organ from his body, but simply to the fact that he has never practised the art. Nor is the failing confined to the quite uneducated. We all of us spend half of our time in misunderstanding our neighbour, and in most controversies misunderstanding is the dividing line between the parties concerned. Now the power of sympathetic insight is trained by a literary education. A man learns above all from the study of literature and history to put himself in the place of other men, races and times, to identify himself with them, to see what they mean and how they felt. And so, by continual practice, he becomes quick at seizing the views of other people than himself, seeing what is in their mind, and accommodating himself to it. 
Here physical science gives no help. In literature the mind must continually be moving from one place to another; in twenty-five pages the reader must successively become Polonius, Hamlet, Horatio, Laertes, Gertrude-to mention no other characters of the play. In fact, he must do, what the merchant does who wishes to sell goods in half a dozen different markets, or the statesman who has to consider the interests and temper of half a dozen different classes and nationalities. But science keeps on one plane; she is not puzzled by the subtle and profound variations of outlook which separate a Russian from an Englishman, a Herefordshire farmer from a Tyneside artisan. Minerals and nerves, alkalis and engines have no point of view, no outlook on life, into which it is necessary to enter; understanding them is very different from understanding Shakespeare or Euripides. You deal with them and all the while remain your own insulated self. Science does not train sympathy, because nothing in its subject-matter has feelings with which we can sympathise.

So far the work of the humanities in education is obvious ; but its further task, though often for- 
gotten, is perhaps the most important of all. Jowett was thinking of it when he said to Matthew Arnold, then professor of poetry at Oxford, "Teach us not to criticise, but to enjoy." Hitherto we have seen how the humanities teach us to criticise; now we are concerned with their second lesson.

Imaginative literature in prose or poetry helps us in our turn to see the world with imagination,

The poet in a golden clime was born, With golden stars above.

But the ordinary man is not born in a golden clime, and though his happiness, and in the best sense, his success, depends on his reaching it, little in his surroundings helps him to do so. He was probably born among smoke and red brick; there is not much beauty in the streets around him; the literature which in the ordinary course he is most certain to see, is the daily press; and here too, he will get little help. On his paper's first page, he will see (typical of the whole) the three most wonderful events of life, presented by a bare enumeration of dates, names and places, and as he turns the sheets, life unrolls itself before him in a list of Stock Exchange prices, law court reports and so on. None of this suggests the golden 


\section{4

clime; nor is its atmosphere one which man breathes with delight.

Besides human nature is sleepy. It suffers from a pervading apathy. The world is full of an incredible wonder, and yet somehow we are not much stirred. Horrible things happen, but we are not moved by their horror; we read of Zeppelin raids, and unless we have suffered ourselves, we do not realise the horror and havoc of bombs dropped in a crowded street of peaceful families. How much heroism lies behind the bare announcements of V.C.'s and D.S.O.'s, and yet how little of it pierces through the black type as we read our paper! We know that our feelings would have been different, if we had seen the actions which they reward, but not having seen them, we remain untouched. Almost any line of a daily paper conceals romance, but we tramp through it as we walk over a ploughed field in January, unconscious of the wealth and beauty that lie germinating just below the soil.

An idle poet here and there

Looks round him, but for all the rest,

The world, unfathomably fair,

Is duller than a witling's jest.

How then does literature help us? I can 


\section{THE HUMANITIES}

illustrate my point best by some examples. Take the following passage from a daily paper on the day following the Queen's Diamond Jubilee: "The Queen left Buckingham Palace yesterday at Io a.m. and drove amid the plaudits of the crowd. . . The German Emperor and the King of Portugal will leave Charing Cross to-morrow at IO.I 5 p.m. by special train for Dover on their way to the Continent." Now see the same event through a poet's eyes.

The tumult and the shouting dies;

The captains and the kings depart :

Still stands Thine ancient sacrifice,

An humble and a contrite heart.

Lord God of Hosts, be with us yet,

Lest we forget-lest we forget !

If Kipling had never written that poem, or if we had never read it, we should have viewed the Diamond Jubilee very differently. He taught us to see it with imagination, he lifted us for a moment into the golden clime. And how much poorer should we have been had he not done so!

Another instance. The press of the war is on us, and we are swallowed up in a bewildering crowd of urgent problems, doubts, dangers, successes. Our object seems to kill German trade, 
to stop German imports, to encourage the descent of the mark, to take Achi Baba or defend Salonika, to relieve Kut, to break the German line in the West, to munition Russia, to bring Rumania in on the side of the Allies. This is in October, I9I 5, and in October, r9r6, a number of other aims, different in detail, similar in kind, will be engaging us. Now let a poet shew us the real issues at stake in war, the spirit and meaning of the struggle in which we are immersed:

It is not to be thought of that the Flood

Of British freedom, which to the open Sea

Of the world's praise from dark antiquity

Hath flowed, "with pomp of waters unwithstood,"

Roused though it be full often to a mood

Which spurns the check of salutary bands,

That this most famous Stream in Bogs and Sands

Should perish; and to evil and to good

Be lost for ever. In our Halls is hung

Armoury of the invincible Knights of old:

We must be free or die, who speak the tongue

That Shakespeare spake; the faith and morals hold

Which Milton held.-In every thing we are sprung

Of Earth's first blood, have titles manifold.

I have drawn my instances from a limited field, but everywhere it is the same. Everywhere the world suffers from its aeonian disease-there is no open vision; and where there is no open vision 
the people perishes. Everywhere we are weighed under the burden of which Goethe spoke, "was uns alle bändigt, das Gemeine." Both in politics and in life we are inevitably immersed in details, and forget to see with the eyes of imagination. We run no risk of overlooking the details, they force themselves on us and prevail. The newspapers will never fail to remind us that the German emperor left Victoria at IO.I 5 p.m., and that fats are trickling into Germany in spite of Orders in Council. But we may easily miss the illumination by which we can see the whole sub specie aeternitatis, the light without which the whole body is full of darkness. Our power of delight is impoverished; we are actually unhappier if the Diamond Jubilee is to us a mere moving past of elaborately dressed men along well-known streets in accordance with a fixed time table, and not the vision of Kipling. Our practical success suffers if we are not able to rise from the obvious details and compelling instincts of the moment to a wider point of view. If anyone doubts this, let him turn from a leader of the on the war to Wordsworth's sonnet, and ask himself whether the change does not make him wiser as well as happier. Or let him remember what Burke said in reference 
to one of the great disasters of our history, the loss of the American colonies: "We ought to auspicate all our public proceeding ... with the old warning of the Church, Sursum Corda." And if this is true of politics, it is also necessary in life as a whole to lift up our hearts. Here it is that the poets and men of imagination help us. They touch the springs of our hearts, and let the poet in us loose.

That is why literature holds so important a place in education. It is a country where the light of imagination is continual, and all things are illuminated by it. It is the world we know, inhabited by the men and women around us. The Grecian urn of Keats was a black clay vessel, with white and red figures, in a glass case in a Museum, his nightingale and Shelley's skylark and Wordsworth's cuckoo are the birds of our fields; the England of Wordsworth's sonnets is the same country whose soil is beneath our feet; we have all met Kent and Horatio, Imogen, Cordelia and Juliet, or we have been very singular. Only, since we are not poets, our eyes have been held, and we have not known the meaning of what we saw. But the poet sees the secret beauty and inner significance of things,- - whether it be 


\section{THE HUMANITIES}

Nature, as when Keats describes a wood on a still night,

As when upon a trancèd summer night,

Those green-robed senators of mighty woods,

Tall oaks, branch-charmed by the earnest stars,

Dream, and so dream all night without a stir;

or a building, as Propertius outside a gate in Rome divines its inner life and history:

Quae fueram magnis olim patefacta triumphis,

Ianua Tarpeiae nota pudicitiae;

Cuius inaurati celebrarunt limina currus,

Captorum lacrimis umida supplicibus, ${ }^{1}$

or men fallen in battle for their country, as Lowell writes of the dead Harvard alumni :

\section{Salute the sacred dead,}

Who went, and who return not.-Say not so! . .

We rather seem the dead that stayed behind.

Blow, trumpets! all your exultations blow!

For never shall their aureoled presence lack...

They come transfigured back,

Secure from change in their high-hearted ways.

We are happier, wiser, better, for being taught thus to see the world.

1i. I6. I ff. 'I, the gate, once flung open to great triumphs, the gate known to Tarpeia's shame; whose threshold has been crowded with gilded chariots, and wet with captives' supplicating tears.' 


\section{0}

\section{CLASSICAL EDUCATION}

So instead of handing our youth over wholly to mathematics, to live with the abstract skeleton of the world, or to science, to study the causes of the phenomena of the physical universe, we hand him over to literature, to the prophets of humanity, in the hope that he may learn to see the world as they saw it, and catch something of their joy, nobility and inspiration. 'This is not to surrender him to idleness or day-dreams. Shakespeare and Milton, Bacon and Burke were not the worse men of business because they had genius. Indeed imagination is necessary to the highest success in any way of life. Its possession raised Rhodes above a mere money-maker, and made Gladstone and Disraeli more than mere politicians. Without it, a man may be a "flourishing earthworm"; he will never be great, he will hardly be a man. Imagination is like the soul in Matthew Arnold's poem :

Still does the Soul from its lone fastness high

Upon our life a ruling effluence send;

And when it fails, fight as we will, we die, And while it lasts we cannot wholly end.

In writing thus I do not of course intend to throw a puny dart at physical science, or to dispute its place in education. Obviously we want more belief in it everywhere, more application of it in 
our industries, and possibly more, certainly better, teaching of it in our schools. To be ignorant of the world in which we live, to have no idea how plants and animals grow, of how the earth came to wear its present appearance, to know nothing of electricity and chemistry, is to deny ourselves whole provinces of knowledge, and the pleasure that comes from their possession; it is to pluck out an eye, and cut off a limb, in order, not to enter into the kingdom of heaven, but to exclude ourselves from part of the kingdom of man. Further, physical science corrects. the vices of a literary training, its tendency to make men retrospective, critical, inactive spectators of the world. She turns the eye forward, because her goal is in the future; she gives a sense of power because her own power is so immense; she exhorts us to act because she is so fruitful in results. Obviously any good education will include the teaching of science. But at the moment the public is in danger of being mesmerised by the word-it is continually being mesmerised by words-and is inclined to regard it as a skeleton key to unlock all doors, a universal medicine to cure all diseases. Unfortunately physical science is not this. It is no use thinking that she can, even partly, take the 
place of the humanities, or that we can get from her what we get from them. It would be as sensible to suppose that by increasing the quantity of fats in our diet we could entirely dispense with albumen. We have already indicated what science fails to do. She studies things rather than man, and where she studies him, studies only his physical, and least important aspect; we shall learn little from her of human nature. She can never teach us to enter into other men's minds; one of the most obvious weaknesses of the mere scientist is the difficulty of making him see other points of view than his own. She is of herself unimaginative, for her business is with the causes of things not with their spiritual values; and though her great representatives have brought imagination with them to their work, the quality is curiously absent in her lesser lights. Nor does she make her followers good guides in regions outside her own confined kingdom. When he leaves it, the scientist is no better judge of the right road than anyone else, and if all his training has been in science, he is probably considerably worse. Anyone who reads the biographies of scientific men, while he admires the infinite patience, subtlety, sureness and humility of mind 


\section{THE HUMANITIES}

shewn in their scientific work, will be amazed to find them making astonishing statements on matters which lie outside it. 'For many years,' wrote Darwin, ' I cannot endure to read a line of poetry. I have tried lately to read Shakespeare, and found it so intensely dull that it nauseated me. I have also almost lost my taste for pictures or music.' ${ }^{1}$ Metchnikoff, wishing to prove that persons, who live sufficiently long, welcome death, actually argues seriously from the (quite mythical) ages attributed in the Bible to the patriarchs, and even says that "old and full of days" (the phrase used of Job) "simply refers to the instinct of death developed in well-preserved old men who had attained ages of from I 40 to 180 years." 2 Herbert Spencer writes: "I have seen nothing more of Carlyle's (Life of) Cromwell than is to be gathered from the reviews. As you correctly surmise, I have no intention of wading through it. . . . I find so many things to think about in this world of ours, that I cannot afford to spend a week in estimating the character of a man who lived two centuries ago." 3 Spencer's

${ }^{1}$ Life and Letters, i. 100.

${ }^{2}$ The Nature of Man (English translation), p. $28 \mathrm{I}$.

${ }^{3}$ Autobiography, i. 295. 


\section{CLASSICAL EDUCATION}

Autobiography contains many examples of dogmatic fatuity, but none more striking than this implicit rejection of the study of history, as unworthy of an intelligent man.

Our danger in education to-day comes, not from men of science as a whole, but from her less liberal devotees, and from that part of the public, which (in a thoroughly unscientific spirit) talks about education without studying it. While supporting any attempt to improve the teaching of science where it is deficient, and to bring more science where it is needed in national life, we shall remember that an education based on physical science would not only leave the mind unflexible, unsympathetic, unimaginative, undeveloped, but would ignore what is more important than the Cosmos itself. Our motto was written 2500 years ago on the walls of the temple of Apollo at

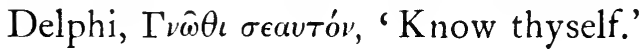




\section{CHAPTER III}

\section{THE CASE FOR THE CLASSICS: GREEK}

To know himself a man must know the capabilities and performances of the human spirit; and the value of the humanities, of Altertumswissenschaft, the science of antiquity, is, that it affords for this purpose an unsurpassed source of light and stimulus. Whoever seeks help for knowing himself from knowing the capabilities and performances of the human spirit, will nowhere find a more fruitful object of study than in the achievements of Greece in literature and the arts.

Matthew Arnold.

GREECE and her foundations are

Built below the tide of war,

Based on the crystalline sea

Of thought and its eternity.

Shelley.

In our last chapter we saw that an education based on physical science, whether regarded as a training of the mind or as an introduction to life, would leave serious gaps, which only the humanities can fill ; and though people sometimes write and speak as if this were not so, no one who has thought 
about education would deny it. We now pass to a much more difficult and disputed point-Why should the classics have a place in our education? Why should they be taught to any except a few specialists, who happen to be interested in them? Why should they hold their present position in our public schools? Why should they not be entirely replaced by our own and other modern languages, literatures and history? With these questions we shall be occupied for the rest of the book.

Some people would explain our classical system as a survival, an anachronism. In the Middle Ages, from which our education dates, "Latin was made the groundwork of education; not for the beauty of its classical literature, not because the study of a dead language was the best mental gymnastic . . but because it was the language of educated men throughout Western Europe, employed for public business, literature, philosophy and science, above all . . essential to the unity of the Western Church." 1 Greek on the other hand took place at its side as offering the fifteenth century, not only finer prose and poetry, but also better text-books in philosophy and science

${ }^{1}$ Essays on a Liberal Education, p. 7. 
than any contemporary literature. The needs, it is argued, which brought Greek and Latin into our curriculum have disappeared or are met in other ways; but the classics still occupy their places by vis inertiae and the favour of a supine nation that has never troubled to dislodge them.

This is on the whole a true account of the origin of our classical education; though it cannot explain why $W$. von Humboldt, founding in I 8 IO A.D. the education which was to regenerate Germany, made Greek a compulsory subject in secondary education, or why the modern world still retains Plato and Aristotle and the masters of Greek literature, though it no longer approaches science through Greek researches or medicine through Hippocrates and Galen. But it assumes too easily that the classics are superseded or rivalled, and that is just what has to be proved. Those who think to discredit Latin and Greek by references to the needs which brought them into education, are making the familiar confusion between origin and validity. A habit or institution may originate in a certain need, and yet be valuable for other reasons when that particular need has passed away. The stars were originally observed because people hoped to read in them human destinies; yet no 
one would discard astronomy because it has developed out of a superstition. The characteristic forms of Greek architecture which still meet us in our streets, were devised to meet the difficulties of building in wood; yet no one would suggest that they should have been abandoned, when the progress of architecture made them no longer strictly necessary. The classics may have taken their place in education because they were once the only keys to knowledge; but it does not follow that they should be condemned because they are no longer required for this particular purpose. Still, it is a paradox that the twentieth century should study literatures 2000 years old; it is a paradox that does not stand by itself, for the Bible is as old as Latin and Greek, and yet we study it; but its defenders are bound to justify it, and shew reason when they maintain, "No man having drunk old wine desireth new ; for he saith, The old is better." What are our reasons?

It is not true that we only study Latin because men spoke it in the Middle Ages, and Greek because there was a time when the fullest knowledge of various sciences was contained in Greek books. But it is true that the history of Greece 
and Rome is the history of the origins of the modern world and that this is one of the reasons why we study them. We live in the West; our ideals are not those of an Indian or a Chinese; our energies are otherwise directed. We admire activity where they seek calm: we believe in knowledge where they rest on hoary tradition: we respect energy, they dignity; we have a vocabulary of ideals-progress, democracy, originality, empire-which repel or leave them indifferent. Whence came this Western attitude so foreign to the East? What fixed this deep gulf to divide humanity? Who created the spiritual atmosphere which we breathe? If we wish to press the questions, we are thrown back on the history of our origins, on the makers of Europe.

Here we are soon reduced to a few elements. No doubt the web is more complicated than we suspect, the colours that cross and recross it are really past counting. But for practical purposes we may say that there are four main threads in the fabric of Modern Europe. We can trace back our descent, and with it many of our traditions and some of our institutions, to Teuton or Celt. Yet the limits of our inheritance from them grow clear 
when we remember that they adopted a civilisation from elsewhere rather than developed one of their own. We can trace back our religious ideas to Judaea: yet these, in their origin Oriental, have been deeply dyed with colours more Western. And if we take our religion from the Jew, what other features of our civilisation come from him? The aims and occupations of our daily life, our political catchwords, our intellectual ideals are not Jewish. Science, art, culture were ideas strange to the Jews of Palestine, and have no part in the history of their nation, while it remained a nation. Our political terms, aristocracy, democracy, imperialism, the very word politics itself, take us back by their derivation to the language of some race, more interested in these questions than the descendants of Shem. We must turn elsewhere than to Judaea for something which can properly be called a civilisation. It needs little seeking. Always on the horizon, for any European who chooses to look back, stand two gigantic figures, the Roman and the Greek, whose achievements have haunted and fascinated the world, from Alaric's Goths lingering spell-bound in Italy down to Renaissance scholars, down to Winckelmann and Goethe, down to our own day. We cannot 
escape from the consuls and senate and empire of Rome-from the buildings and sculpture of Periclean Athens, from the writings of Plato and Aristotle, from the museum of Alexandria-in a word, from Greece or Rome. Certainly if we are curious to explain our characters by heredity, we cannot ignore our spiritual ancestors.

Imagine for a moment that we had never heard the names of Greece and Rome. What should we lose by our ignorance? Those of us who read poetry would find much that was unintelligible in English authors, in all English poets, I think, without exception, from Chaucer to Rupert Brooke. We should not know in Julius Caesar what the tribunes or the Capitol were, or how Brutus and Antony came to be the heroes of Shakespeare; we should wonder what we were missing when Tragedy

In sceptred pall came sweeping by,

Presenting Thebes, or Pelops' line,

Or the tale of Troy divine.

We should not know what sort of thing was that Greek urn which moved Keats to song. We should see that our poets had had the entry to a world from which we were excluded, a world of some strange charm and beauty, for they moved 
in it as happily and as delightfully as in their own. Then, again, the key to much of our own language would have disappeared. Most of its vocabulary would be mere sounds to us, calling up certain ideas, but leaving us quite ignorant how the words came to have their particular meaning; and this would be so, not only with words like subliminal, hypochondriac, acolyte, centripetal, exogamy, but with quite common expressions, angel, planet, revolution, Bible, conscience, etc. Further, the technicai terminology of medicine, botany and many other sciences would be a meaningless jargon.

More serious would be the descent of darkness on the origins of nearly all our civilisation. We should be different from Indians or Chinese, but we should not know why; certain words would be continually on our lips, certain ideals constantly before our eyes, but we should not know whence they had come. Politics, astronomy, magnanimity, Caesarism, empire, municipality, federalism, drama, history, religion, urbanity, metaphysics, anatomy, scepticism, rationalism, and a thousand others-we should know what these words meant to us, but we should be ignorant who first had used them, who invented democracy, the name and the thing, and what success its 
inventors had with their experiment, who first called the study of human destiny philosophy, and along what paths of thought his 'love of wisdom' took him. Equally dark would be the origin of many of our institutions, including much in our legal system, and of arithmetic, geometry, astronomy, meteorology, medicine and other sciences (the names of nearly all the sciences betray their descent). We should not know from what seed of original inspiration had come the architectural style of most of our public buildings and many of our churches. Much in Christianity itself would be obscure; even a doctrine so central as that of the Word, in the opening chapter of $\mathrm{S}$. John's Gospel, would have lost its explanation, if we had never heard of Greece. The rustic who walks along a Roman road or finds in his field the tessellae of a Roman pavement, has no idea how they came to be there; and we, like him, though in more important matters, should live ignorant of the rock whence we were hewn and the pit whence we were digged.

This is one reason for studying the classics, and a great scholar like Wilamowitz-Moellendorff bases his defence of them upon it. A man can hardly be said to be educated, who knows nothing 
of his spiritual ancestors, and he shews a curious indifference of mind if he is content to remain so. But there are more practical grounds than these. We may infer them by noticing the character of ages when the world has lived in ignorance of the past ; they have been marked by mental lethargy and superstitious conservatism, whereas the epochs in which men have looked back to their origins have been ages of change, progress, vigorous life. The Renaissance was a study of origins; so was the Reformation; so were most renewals of art from Cinque Cento architecture to pre-Raphaelitism; Winckelmann and Goethe turned back to Greece; Strauss and Baur sought, not very happily, after primitive Christianity. A man who knows the origins of the world in which he lives, looks at it with more understanding, walks in it with securer and more certain steps; he is less intimidated by words, for he knows their history, less inclined to either excessive respect or contempt for existing institutions, for he sees how they came to be there. He understands the world better, as parents understand a child whom they have known from its cradle better than a stranger understands him, and he is more confident and capable in handling it. When Darwin went back to origins 
in the history of natural creation, he taught us that the nature of things could not be understood without knowing their history. We should be forgetting his lesson, and wilfully blinding ourselves, if we turned our backs on the origins of modern Europe.

Still, this is not the strongest argument for the classics; it is possible to live ignorant of the book of our history and to guess from its later chapters what we have never read; though such guesswork may lead to errors and misconstructions. If the classics are to stand, they must do so on their own merits; the final answer to anyone who asks why we read them must be: Look at Greek literature and Roman civilisation: listen to what the great moderns have said about them. Hear Goethe: "Of all peoples the Greeks have dreamt the dream of life best." I Hear Coleridge: "The Greeks were the masters of all grace, elegance, proportion, fancy, dignity, majesty, of whatever, in short, is capable of being conveyed by defined forms of thought." Hear Shelley: "Although the scheme of Athenian society was deformed by many imperfections which the poetry existing in

${ }^{1}$ Maxims and Refiections, tr. Bailey Saunders, p. 99. 
chivalry and Christianity has erased from the habits and institutions of modern Europe; yet never at any other period has so much energy, beauty, and virtue been developed; never was blind strength and stubborn form so disciplined and rendered subject to the will of man, or that will less repugnant to the dictates of the beautiful and the true, as during the century which preceded the death of Socrates. Of no other epoch in the history of our species have we records and fragments stamped so visibly with the image of the divinity in man." 1 Hear Matthew Arnold: "I fearlessly assert that Hermann and Dorothea, Childe Harold, Jocelyn, The Excursion leave the reader cold in comparison with the effect produced upon him by the latter books of the Iliad, by the Oresteia, or by the episode of Dido. And why is this? Simply because in the three latter cases the action is greater, the personages nobler, the situation more intense: and this is the true basis of the interest in a poetical work, and this alone." And again: "Shakespeare has not the severe and scrupulous self-restraint of the ancients, partly, no doubt, because he had a far less cultivated and exacting audience: he has indeed a far wider range than 
they had, a far richer fertility of thought: in this respect he rises above them: in his strong conception of his subject, in the genuine way in which he is penetrated with it, he resembles them, and is unlike the moderns: but in the accurate limitation of it, the conscientious rejection of superfluities, the simple and rigorous development of it from the first line of his work to the last, he falls below them and comes nearer to the moderns. In his chief works, besides what he has of his own, he has the elementary soundness of the ancients; he has their important action and their large and broad manner; but he has not their purity of method. He is therefore a less safe model; for what he has of his own is personal, and inseparable from his own rich nature; it may be imitated and exaggerated, it cannot be learned or applied as an art; he is above all suggestive: more valuable therefore to young writers, as men than as artists, But clearness of arrangement, rigour of development, simplicity of style-these may to a certain extent be learned: and these may, I am convinced, be learned best from the ancients, who, although infinitely less suggestive than Shakespeare, are thus, to the artist, more instructive." 1

1 Preface to Poems. 
Unfortunately the testimonies of these prophets will be mere words to anyone who does not know Greek or Latin, or who has been taught them badly. A Chinaman, ignorant of the West, would not be illuminated if we spoke to him of the glories of English literature or the importance of the French Revolution. We may praise the Greeks endlessly; we may urge the strength of their literature where our own is weak, and speak of its unfailing perfection of form, its habit of never wasting words, its directness, naturalness, freedom from affectation and sentimentality and bad taste; we may urge that the study of such models will save us from the faults to which we are very liable; but it will all mean very little to those who do not know the classics already.

How are we to bring their excellence home to the doubter? Best perhaps, by asking him, before he judges, to read the first half of the sixth book of Plato's Republic, and the Phaedo from chapter 56 to the end, the sixth and seventh books of Thucydides, the Oresteia in Morshead's translation, and Prof. Murray's versions of the Medea, Iphigeneia, Hippolytus and Bacchae. $\mathrm{He}$ will then learn, even through the medium of English, the kind of thing Greek literature is, its sincerity 
and simplicity, its power of taking us past all veils and external trappings to the very heart of humanity, its conciseness and habit of packing masterpieces into a few pages.

Or we may give an idea of the quality of the classics by speaking of letters, such as most schoolmasters and College tutors have received since the War began from many parts of the front. This from a cellar in Ypres: "I am most genuinely looking forward to the time, about five weeks hence, when we are due to go back to St. Omer, where I am getting _ _ to send me out a selection which I hope will include Homer, some Vergil, Lucretius v.

(Noctivagaeque faces coeli fammaeque volantes

Et rapidi fremitus et murmura magna minarum

just hits off trench life and great guns firing), some Robert Browning, King Lear, Lucas' Open Road and the Agamemnon." Or this from Gallipoli (the writer is a history scholar who dropped his classics when he went up to Oxford): "I wish I could describe to you either dawn or sunset here. All the Greek epithets in Homer, like 'wine-dark' and 'rosy-fingered,' mean here all they say. If I return home safely, I will read Homer again for the sheer pleasure of realising all that his adjectives 
mean." Or this, written before the battle of Loos: "Thucydides is a gentleman whose truth I never appreciated so thoroughly before. In his description of the last great effort of the Athenians to break into Syracuse he tells how the officers lectured and encouraged their men right up to the last moment, always remembering another last word of counsel, and wishing to say more, yet feeling all the time that however much they said it would still be inadequate. Just the same with us now. We've all lectured our platoons, but something still keeps turning up, and after all we can only play an infinitesimal part in Armageddon! Well, we're parading in a minute." 1

But there are two ways of appreciating the significance of the classics, which anyone can take. For the first it is necessary to be in London in time of peace, for the second to be able and willing to read.

First, go into the British Museum and walk through the Greek Sculpture rooms; look at their greatest glory, the sculptures from the Parthenon frieze, and ask whether these have not, beyond most things, the quality which Goethe attributed

${ }^{1}$ From a letter by Lieut. Windle, quoted in the Times History of the War, pt. 75 . 
to the Homeric hymns: "Even to this day they have the power of freeing us, at any rate for a moment, from the frightful burden which the tradition of several thousand years has rolled upon us." 1 Before you leave them, note the technique of the drapery; and, as you leave, glance at the portrait busts of the Roman Emperors. Then go to Parliament Square, where the nineteenth century has placed its great statesmen, men certainly not less remarkable than Vespasian or Trajan or Verus; observe their inanimate faces, their inert pose, and the leaden droop of their clumsily modelled dress. 'Then ask whether the civilisations which produced the dead artists of Greece and Rome do not excite wonder and curiosity, and offer something as unique in its way as Shakespeare or any light of the modern world.

But if we are not in London, there is another easy way of awakening our imaginations to the significance, at least of Greece. Suppose some one told us that in a small country called Greece there was a city not so big as Portsmouth, whose independence passed away in the fourth century before Christ, and which after that date had no political influence on the world; yet that the

$$
\text { 1.c. p. I62. }
$$


Roman Empire, which extended from the Euphrates to the Clyde, from the Elbe to Assouan, enthusiastically adopted the civilisation of this small country, regarded its capital as the intellectual centre of the world, placed the education of the young Roman in Greek hands, took its philosophy of life from Greece, depended on Greek sculptors and painters for its art, learnt from Greek models to write poetry, history, oratory and every branch of literature without exception, while the greatest of Roman men of letters wrote: "Athens, the mother of civilisation, learning, agriculture, religion, justice, law." I Suppose, further, we knew that when the civilisation of Rome withered in a winter of barbarism, the re-discovery of Greek classical literature brought the world that sudden, joyous, brilliant springtime called the Renaissance, of which we are now in the full summer and from which our modern politics, letters, art, thought, science are directly derived. Suppose we noted that not only in the fourteenth century, but at all times, the study of Greece had created a sudden intoxication of the human spirit; should we not be curious as to the civilisation which had such a unique influence? Should we not see in it a ${ }^{1}$ Cicero, Pro Flacco, $\$ 62$. 


\section{THE CASE FOR GREEK}

unique intellectual ferment, and suspect that its prominence in education was due to this power?

What is the secret of the classics? We shall perhaps learn it if we ask the ages or individuals to whom Greece came as a revelation, what they saw in her. Take the Makers of the Renaissance first. They were born in an age ignorant, superstitious, fanatical, when learning was scholastic and Latin barbarous, when thought struggled feebly against the engulfing darkness, and ecclesiastical tyranny kept a jealous eye on free speech and speculation, when literature knew but one splendid and solitary luminary, and art some minor and fitful lights. Suddenly as they hungrily deciphered their Latin and Greek manuscripts, a new life was revealed to them. Here were men who could write poetry, history, speeches, philosophy with a grace, ease and power such as they had never seen ; who were politicians, soldiers, athletes, thinkers, poets; who lived a many-sided, many-coloured life unfettered by church or state; who boldly discussed without fear of priest or pope all things in heaven and earth, followed after wisdom and seemed to find it, yet so that the search took them not into a dusty desert of scholasticism, but into 
fields of beauty and delight. They opened Thucydides and read: "Our constitution is named a democracy because it is in the hands not of the few but of the many. But our laws secure equal justice for all in their private disputes, and our public opinion welcomes and honours talent in every branch of achievement, not for any sectional reason but on grounds of excellence alone. And as we give free play to all in our public life, so we carry the same spirit into our daily relations with one another. We have no black looks or angry words for our neighbour if he enjoys himself in his own way, and we abstain from the little acts of churlishness which, though they leave no mark, yet cause annoyance to whoso notes them. Open and friendly in our private intercourse, in our public acts we keep strictly within the control of law. We acknowledge the restraint of reverence; we are obedient to whomsoever is set in authority and to the laws, more especially to those which offer protection to the oppressed and those unwritten ordinances whose transgression brings admitted shame. Yet ours is no workaday city only. No other provides so many recreations for the spiritcontests and sacrifices all the year round, and beauty in our public buildings to cheer the heart 
and delight the eye day by day." I Surely these were men and this was a life for men to lead: and by these Greek patterns and this vision of Greece the life of the world was renewed.

Five hundred years have passed: what has Greece to teach to us? The fetters that bind us are not ecclesiastical. We are let and hindered by the common infirmity of all men, dullness of imagination; and further by the peculiar vices of our age, materialism, commercialism, the narrowness, ugliness, rush, luxury and economic pressure of life; and to us in our way as to the men of the Renaissance in theirs, there is a healing efficacy in the life of these

Little towns by river or sea-shore,

Or mountain built with peaceful citadel,

where there were no advertisements or cinemas or electric trams, little smoke and only human noises, whose greatest luxury was fish and whose life was of a fullness denied to or refused by most of us.

I have a letter from a working-man who had come across a book on the Greeks and who writes: "I believe that it is this great Hellenic spirit consciously and unconsciously seeking expression which is the cause of the great industrial

$$
\text { iii. } 3 \text { - f., tr. Zimmern }
$$


unrest of this and other lands; we are not covetous for the rich man's gold or land, only in so far as we realise that they are the economic bases of life, and it is life that we want, full, rich, free and manysided. The book enabled me to do that which unaided I could not do, viz. get to the marrow of Greek life, which to me is the only life." I have printed the letter as it stands; we may agree or not with the speaker's views, but the striking thing is that Greece suggests these thoughts, and means all this to a Welsh ironfounder in the twentieth century, who happens to come across a book on her. There we have an exact repetition of what happened in the fourteenth century. The Briton sees in Athens a picture of the Ideal State, as the Renaissance saw in it a picture of the Ideal Man, and thereby witnesses to its continuing power to be a pillar of fire in the dark journey of humanity. The older the world grows, the more heavily the burdens of wealth and knowledge and complex civilisation weigh it down, the more eagerly it will look back to the many-coloured, many-sided life which humanity once led in Athens. "There it would have been possible to find the same man, at different times sitting at a cobbler's bench, listening to the Bacchae, voting in the Assembly, a 


\section{THE CASE FOR GREEK}

worshipper in the temples, a soldier on campaign, a juror in the courts. We cannot indeed revive that Greek world in which poets were soldiers, and politicians generals, and every man a member of Parliament, nor should we wish to do so. But we can try to catch a portion of its spirit. This existence, whatever its faults may have been, had not the grinding specialism of the modern world. Here no one was absorbed by his trade or livelihood; but a man remained in the first place a human being, and exercised the gifts, and experienced the enjoyments, proper to human nature. The artisan did not become a machine, or the labourer a drudge. The soldier, the merchant, the man of letters did not slip into narrow professionalism. The historian derived his knowledge of politics and war from hours spent in the assembly and the camp. The poet and the philosopher had been in touch with that human nature on which they moralized and wrote." 1 That spectacle, that ideal only grows more fascinating and salutary with time.

But it is not on the picture of a civilisation, the pattern of a complete man, which Greece

${ }^{1}$ Livingstone, The Greek Genius and its Meaning to us, p. I -8 f. 
offers, that I wish to dwell. That is an argument, like the argument from Greek literature, too big to be compressed into a chapter; and at the end some one might say: "We are not men of the fourteenth century, we have riches of our own to go to; and if the spectacle of a full, rich life is what we want, Shakespeare and English literature can do for us what the classics did for them." Instead, I will deal with a quality of Greece which is easier to put on paper, which no one has possessed quite like her, which is the heart of her achievement, and the secret of her fermenting power; a quality, too, which is indispensable to the modern world. It is that creative intelligence, which was earlier spoken of as Greece's chief contribution to the world.

Survey for a moment the achievement of Greece. While human intelligence was hibernating in Egypt and Assyria, ridden by a priestly or military or dynastic caste, while the brains of Carthage went to commerce and money-making, Greece, with no precedent to guide, no surrounding culture to support her, produced an epic, which as pure literature, and as a picture of heroic human life, has never been surpassed, and so started on that career of intellectual activity, of which tragedy, 
comedy, history, oratory, Platonism, Stoicism, Epicureanism and a dozen other philosophies were the fruits. Less familiar to us and hardly less remarkable are the achievements, which may be read in Professor Burnet's Early' Greek Philosophy and Susemihl's history of Alexandrian literature. From the small cities on the Aegean coasts came the idea of giving a rational account of the universe, its shape, composition and behaviour, and with the idea, guesses, often wild, as was to be expected, but which contain the seeds of modern thought. Thus Anaximander (550 B.c.) divined that the earth hung in space, the Pythagoreans, that it was a sphere and turned on its own axis. Thus the same Anaximander anticipated the evolution of species; "he says that originally man was made out of animals of a different species, because all other animals are quickly able to feed themselves, while man alone needs nursing; so in view of his nature he could never have survived at first." 1 These are three specimens of the many brilliant guesses of Ionian philosophy. The medical writings of Hippocrates ( 460 B.c.) and his school are more truly scientific, resting as they do on careful observation. "The two treatises ' On fractures,' ${ }^{1}$ Doxographi Graci, F. 579. 
and ' On dislocations' are hardly surpassed in some ways by the writings of the present mechanical age." 1

But the true age of Greek science is the Alexandrian Epoch, when Aristotle had shewn the way to specialisation, and each branch of knowledge flowered by itself. It was an age of erudition like our own, and such nicknames as Chalcenterus (Brazen Guts) and Polyhistor bear witness to its laborious learning. Records, decrees, laws, inscriptions were collected; learned men wrote monographs on games, sacrifices, feasts and every other conceivable subject; they published chronologies, local histories, guides to famous places like the Acropolis, Delphi, Troy, books of travel in India and elsewhere, surveys (there was one of the mountains of the Peloponnese), biographies of famous artists, musicians, men of letters and of action. The literature on Alexander alone was enormous, compiled by writers who, like modern war correspondents, accompanied him on his campaigns, or by those who stayed at home, and built their works on original documents and historical research. Then there were philological works, critical editions of the classics and commentaries ${ }^{1}$ Encycl. Britannica, vol. xxvi. p. 126 (article on "Surgery").

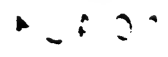


on them, literary histories, studies of the Greek dialects, grammatical treatises. Besides these, there were more scientific works, books on the theory of music and rhythm, on pure and applied mathematics. We can read in third century Greek the axioms, postulates and propositions of our boyhood. Greek astronomers like Hipparchus, Eratosthenes, Eudoxus of Cnidus, and Aristarchus of Samos, named the heavenly bodies, explained their movements, devised methods of measuring their distance and started the heliocentric theory. Eratosthenes compiled the first map on mathematical principles, and marked the earth out with lines of latitude and longitude. Archimedes developed and applied the theory of mechanics. There were books on every subject that could be studied; Varro in the last century B.c. had fifty Greek works on agriculture before him when he wrote his De Re Rustica.

Most of this mass of learning has gone, but had the catalogue of an Alexandrian bookseller survived, we should have seen headings like those in a modern publisher's circular, and realised that the mental activity of that age ran in channels similar to our own. The achievement was wonderful, but time quickly antiquates knowledge, and, but for 
the light its survival would have thrown on antiquity, we have not lost much. (In two thousand years would the disappearance of all modern writings that are not great literature be much missed except by archaeologists?) We can still read in the original the description of Archimedes' giant ship which carried about 800 persons, and the ingenious inventions of Heron of Alexandria, his automatic penny-in-the-slot machine for water, his odometer for measuring distances, his fire-engine, his hydraulic organ, his method of moving a ball by steam (anticipating the principle of the steamengine), his optical devices for shewing ghosts on the stage. Less interesting, but more remarkable are the essay of Archimedes on Number and the theoretical parts of Heron's treatise on Pneumatics, which shew his grasp of scientific method (the sixteenth century took from the latter the saying that Nature abhors a vacuum). They bring home to us one of the great puzzles in the history of civilisation, why, with all that they did, the Greeks did not do a little more, and anticipate the evolution of science which began fifteen centuries later. Their interest to us is in the witness they bear to the Greek's intellectual activity and precocious gift for Science. Later ages under Greek 
inspiration have gone further in exploring the continent of knowledge, but the Greeks were the first to lift up their eyes to the mountain ranges, and conceive the audacious thought that they might be crossed. And it is a higher mark of genius to originate the idea of knowing, than, when originated, to carry it out. ${ }^{1}$

Even with the coming of the Roman Empire this élan vital is not exhausted. Not content with having given a civilisation, a literature and a philosophy to Rome, they create mysticism, and the theory, and practice in literature, of Art for Art's sake; then, retiring before barbarian invasions, brood drowsily in Constantinople over the achievements of the past, till, with their rediscovery by the West, Art, Letters and Thought revive again and

Magnus ab integro sacclorum nascitur ordoThe world's great age begins anew.

And note that all this is Greek work. England, France, Germany and other nations have contributed essential elements to modern civilisation.

${ }^{1}$ For Greek mathematics, see Gow, Short History' of Greek Mathematics.

Iwan Müller's Hondbuch, v. i., gives a sketch (badly written) of Greek science, and references to modern books on it. Wilamowitz's Griechisches Lesebuch contains extracts from Heron 
But the civilisation of the past was the work of one tiny race; Assyria, Egypt, and the surrounding nations contribute nothing to it. Rome herself, on the intellectual side, contributes only when she is fertilised by Greece. .

The secret of this colossal achievement is simple. Greece is the ferment of the intelligence, quickening, permeating all media with life. The Greek genius is the triumph of creative intelligence. In saying this we run a risk, for we evoke an unattractive and misleading picture. Reason to the Englishman suggests something bloodless and wizened, generally embodied in strange and unfamiliar language. We think of Hume or Mill or Henry Sidgwick, of pages of abstract reasoning, colourless and correct, of austere but somewhat arid virtue. Or we think of our modern ' intellectual' writers, acute, critical, cold and often brutal: of plays, from which we rise with thought sharpened, experience widened, and a chilly feeling, as if the theatre had been not a playhouse but an operating room. Greek intellect, at least and others, with useful notes and diagrams. The Pneumatics has been translated into English by Woodcroft. The account of Archimedes' ship, with its gymnasium, temple, bath, gardens and fish tanks, reads like a description of a modern liner (Athenaeus, v. c. 40 f.). 
in the great writers, is not of this sort. Unlike so many moderns, their thinkers are neither dull nor ugly nor brutal. They were saved from such things partly by something in their blood, a love of тò $\kappa a \lambda o ́ v$, partly by their share in public affairs, which brought into their writings the breath of real life and kept them from being mere study work, partly by a sense of civic devotion, which gave their thinking a practical purpose and turned the thinker into a marching apostle of truth. Theirs is intellect of the kind we know in Shakespeare or Milton or Burke. Milton, who knew the hard words the world uses about intellect and its true nature, wrote of it:

How charming is divine philosophy!
Not harsh and crabbed as dull fools suppose,
But musical as is Apollo's lute,
And a perpetual feast of nectared sweets.

And he describes its nature and aims: "The end, then, of learning, is, to repair the ruins of our first parents by regaining to know God aright, and out of that knowledge to love Him, to imitate Him, to be like Him, as we may the nearest, by possessing our souls of true virtue." That is the creative intelligence which the Greeks so supremely possessed. 
Listen to a Greek's description of it at the close of a choric song in praise of Athens:

And Cephisus, the fair-flowing river-

The Cyprian dipping her hand

Hath drawn of his dew, and the shiver

Of her touch is as joy in the land.

For her breathing in fragrance is written,

And in music her path as she goes,

And the cloud of her hair it is litten

With stars of the wind-woven rose.

So fareth she ever and ever,

And forth of her bosom is blown,

As dews on the winds of the river,

An hunger of passions unknown,

Strong Loves of all God-like endeavour,

Whom Wisdom shall throne on her throne. ${ }^{1}$

It is on the closing words of this that I wish to

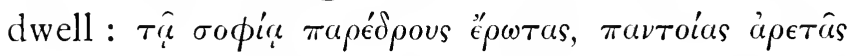

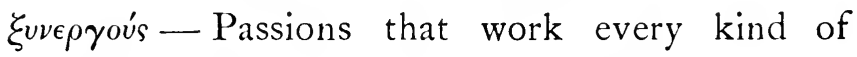
Excellence, throned at the side of Wisdom. Read with careful attention, these seven words reveal a philosophy of life and the genius of a nation; and though the language is strange, the ideal is as noble and living as any ever conceived by human mind. The spirit which Aphrodite, 'the Cyprian,' was to bring to these Athenians was threefold, a ${ }^{1}$ Euripides, Medea, $11.835-845$, tr. Murray. 
spirit of wisdom, of passion, and of excellence, excellence springing out of wisdom and by its beauty exciting passionate desire. The three sides of human nature were expressed in it-the intellectual, the emotional, the moral. It was not cold intellect, for the Greek word " $\rho \omega s$ is the passion of a lover; it was not narrow, for it pervaded all life, and embraced 'every kind of excellence'; it was not mere emotion, or mere morality, for it was ' throned by Wisdom,' aided, disciplined and crowned by the intelligence. That is Greek Reason at its best, not a mere intellectualism watching the world from a study, with keen, dispassionate eyes, but an ardent desire, reaching out into all provinces of life, and seeking to reshape them in accordance with itself.

There is no word for this quality. Reason to our ears, though not to Milton's, would suggest something purely intellectual. Philosophy, 'the love of wisdom,' has the thought; but the word has lost its original meaning, and philosophy for us is something technical and remote from life. Some writers have called it the artistic temperament, ${ }^{1}$ and this description, not entirely satisfac-

${ }^{1}$ Chamberlain, Foundations of the xixth Century, tr. Lees p. $15 \mathrm{ff}$. 
tory, reminds us of its connections and lineage ; for it is the base of poetry as well as of philosophy and science. It is reason joined with vision, not mere intelligence, but creative intelligence; and it is the highest of intellectual qualities. Reason without vision is cold, creeping, inadequate; vision without reason may be fantastic, unreal, either ineffective or dangerous. But the greatest men are neither mere thinkers nor mere dreamers. They are neither like Hume and Locke, nor like Blake and Shelley. In them vision and reason blend ; they dream, but reason controls and orders their vision. They think, but vision reveals to their thought the kingdoms of the earth and the glory of them. With it they soar like eagles; without it they would be wing-clipped fowls with their eyes bent on the farmyard. "Every great poet has been a philosopher, every philosopher of genius, a poet," 1 and in philosophers here must be reckoned the great men of science.

For a large part of its life the world has always depended on this spirit, but no age more than our own. Yet no race has possessed it so fully as the Greeks. It is their secret. They lived in times

${ }^{1}$ Chamberlain, Foundations of the xixth Century, tr. Lees, p. 25 . 


\section{THE CASE FOR GREEK}

when superstition was rife, and the human mind was a tangled jungle; yet no body of men have ever looked at life with eyes so unbiased and frank. Reading Socrates or Aristotle, you feel that they cared for nothing but truth; they have no trace of theological or antitheological prejudice, of personal ambition or spite. They are not intent to foist any views of their own on the world, they are simply concerned to know, profoundly interested in life, and in forming a just and worthy idea of it. They are academic in the good sense of the word. And yet they are not mere intellectuals. Vision, imagination, suffuses their reason, and makes them artists and thinkers in one. The quality is inborn in the Greeks, as individualism is inborn in the Anglo-Saxon, and is exhibited by all their great men. Reason seems to be in their blood. It is as much a mark of Homer and Aeschylus as of Socrates. They became poets or thinkers as the artistic instinct or the reason predominated in each individual, but in all the fond was the same. They saw 'life steadily, and saw it whole.' They possessed 'the top of sovereignty'

\section{To bear all naked truths}

And to envisage circumstance all calm. 
Remembering then that Greek Reason is of this kind, not the mere black and white work of logic, but the coloured art of creative intelligence, let us glance at some examples of it.

Greek literature is full of the key thoughts on which our intellectual life depends. And by this I mean something more than acute and striking sayings such as: "Happiness (єvidarнovia) does not reside in flocks or money; the soul is that spirit's

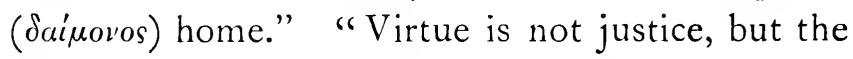
absence of even a wish to be unjust" (Democritus). "A fool is imposed on by every idea." "It is hard to fight passion ( $\theta v \mu o ́ s)$; it will sell its life for its desire" (Heraclitus). "The advantage in being a philosopher is that if all laws disappeared, the philosopher would live as he did before" (Aristippus). "Men who spend their time in chopping logic ( $\delta_{\iota}(\lambda \epsilon \kappa \tau \iota \kappa \eta)$ are like those who eat crabs, and for little nourishment have to contend with a great quantity of shell" (Bion). "Goodness in the true sense, is not possible without moral insight ( $\phi \rho o$ 'v $\sigma \iota s$ ), nor moral insight without goodness." "Wealth lies less in our possessions than in the use we make of them." "To seek utility everywhere is most unsuitable to lofty and free natures." "We should be educated 
from youth to feel pleasure and pain at the right things; this is the true education" (Aristotle). "We would not have our politicians grow up amid images of moral deformity, as in some noxious pasture, and there browse and feed upon many a baneful herb and flower day by day, little by little, until they silently gather a festering mass of corruption in their own soul. Let our artists rather be those who are gifted to discern the true nature of beauty and grace; then will our youth dwell in a land of health, amid fair sights and sounds, and receive the good in every thing; and beauty, the effluence of fair works, shall flow into the eye and ear, like a health-giving breeze from a pure region, and insensibly draw the soul from earliest years into likeness and sympathy with the beauty of reason "(Plato. Contrast this ideal with modern practice as revealed in advertisements and cinema posters).

Such sayings abound in Greek, and the chief difficulty is to stop quoting, but they are also common in other literatures, more common than the key thoughts spoken of above. We could find the same kind of thing in Pascal, Montaigne, Vauvenargues, Amiel ; though it would be difficult anywhere to match the beauty and depth of the 
quotation from Plato. But I am here concerned with something more definitely intellectual than the power of making acute observations, something that betrays an even rarer quality of mind, something that we should not find, I think, in the French writers quoted above-a disinterested desire for knowledge, an instinct and aptitude for finding the rational explanation of things. This quality was otherwise almost unknown in antiquity, and it is not very common to-day. But the Greeks wanted to know things, not for money (they were always a poor people), nor for fame (unlike the Romans, they never talk about it), but simply in order to know. They were interested in irropia, 'inquiry,' as they called it, and the monument of this interest is the creation of science and thought.

The New Testament is full of simple phrases, clear as profound springs, which reveal deep beyond deep of religious truth as we gaze into them. "Whoso will save his life, shall lose it." "Blessed are the pure in heart, for they shall see God." "Except ye become as little children, ye shall not enter into the kingdom of God." "Whosoever will be chief among you, let him be your servant." "Though I bestow all my goods to 
feed the poor, and though I give my body to be burned, and have not love, it profiteth me nothing." These are seeds in whose tiny compass the promise and potentiality of ages of endless growth are concealed. What the Bible is in the world of religion, that Greek literature is in the world of thought, so simple, so memorable, so clear, so illuminating, so instinct with the spirit of reason, so able "mettre la vérité dans un beau jour." We find in it the seminal principles of most of our modern thought stated with the profundity, and often the conciseness, of a New Testament text.

The Greeks were the first to call the universe a кó $\sigma \mu o s$, an 'order', and so declare their conception

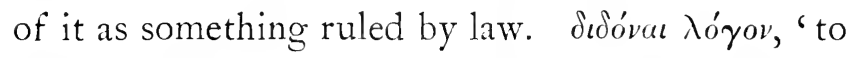
give a rational account of things,' they invented both the phrase and the momentous and enterprising idea. They knew the origin of all thought

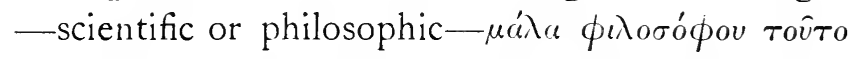

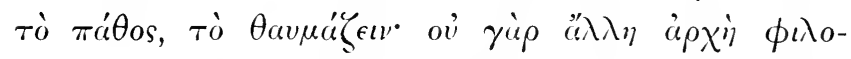

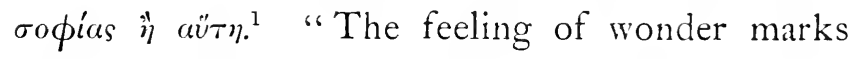
the true philosopher, for this is the only source of philosophy"; and they knew its spirit. "I am one of those who are very willing to be refuted 1 Plato, Theaet. 155. 
if I say anything which is not true, and quite as ready to be refuted as to refute: for I hold that this is the greater gain of the two, just as the gain is greater of being cured of a very great evil than of curing some one else." I And again: "I pray God to grant that my words may endure, in so far as they have been spoken rightly; if unintentionally I have said anything wrong, I pray that he will impose on me the just punishment of him who errs ; and the just punishment is that he should be set right." 2 If Socrates was not a man of science himself, he knew the spirit by which science lives. They knew the conditions of science and philo-

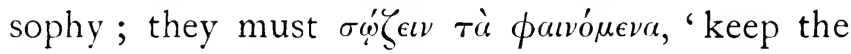
phenomena safe,' as they picturesquely said-a hypothesis must explain the facts without doing violence to them. Concisely and quaintly they defined the method of science. Plato explains that mere right opinion without knowledge is helpless; the man who has it is "like a blind man, who manages to keep in the right road "; ${ }^{3}$ and "true opinions while they abide with us are beautiful and fruitful, but they run away out of the human soul and therefore are not of much value until they

${ }^{1}$ Plato, Gorgias, $458 . \quad$ Id. Critias, 106.

${ }^{3}$ Id. Republic, 506 . 
are tied up by the "tie of the cause," " 1 The tie of the cause, that is the piece of string with which Science still walks the world and turns opinions into knowledge, connecting isolated phenomena by discovering their cause. And they were equally

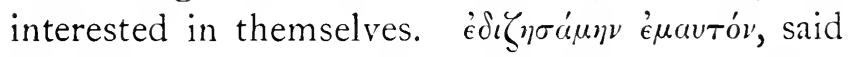
Heraclitus, 'I inquired into myself,' and the phrase opens up the endless branching avenues of philosophy. They had indeed a nobler and wider conception of philosophy than we, with whom philosophy-' the love of wisdom,' and science-' knowledge,' disown their names and are each consigned to a single province of their true kingdom and made jealous members of a loose federation. When they spoke of philosophy they had in their mind the whole range of knowledge from the knowledge of God to that of nature, for they saw the universe as a whole, and regarding it all as the kingdom of man, rejected the narrow specialism of our philosophers and scientists, each shut, like an anchorite, in his small, private cell. Listen to Aristotle on physical science; men of science might take the words as a motto, for never has the study of nature been more nobly praised or more widely conceived.

$$
{ }^{1} \text { ld. Mens, } 9 \text { S. }
$$


"Doubtless," he says, "the glory of the heavenly bodies fills us with more delight than we get from the contemplation of these lowly things (i.e. the facts of zoology); for the sun and stars are born not, neither do they decay, but are eternal and divine. But the heavens are high and afar off, and of celestial things the knowledge that our senses give us is scanty and dim. On the other hand, the living creatures are nigh at hand, and of each and all of them we may gain ample and certain knowledge if we so desire. If a statue please us, shall not the living fill us with delight, all the more if in the spirit of philosophy we search for causes and recognise the evidences of design. Then will Nature's purpose and her deep-seated laws be everywhere revealed, all tending in her multitudinous work to one form or another of the Beautiful." 1

The spirit revealed by these quotations is not common even with us. It looks at life unblinded by pre-conceptions, by sentiment, by regard for what other people think, have thought, or will think. Now turn from its isolated utterances to

${ }^{1}$ De Part. Animalium, i. 5. The translation is taken from Prof. D'A. Thompson's delightful Herbert Spencer lecture on "Aristotle as a Biologist." 


\section{THE CASE FOR GREEK}

its action on life. It was applied to theology, and within less than a hundred years of the time when poets believed that the Father of Heaven tried to eat his own children, that one of them, after deposing him, reigned in his place, bullying his fellow-gods and taking the form of various animals in order to seduce the daughters of men, Plato was writing: "Evil cannot reside in heaven, so it is compelled to haunt mortal nature and our earthly home. Therefore we must try and escape from earth to heaven as quickly as we can: and this escape is to become like God, as far as lies in our power; and to become like him is to become good and holy and at the same time wise (notice this characteristically Greek addition). . . . God is nowhere and in no way unrighteous, he is supremely righteous; and there is nothing more like him than those of us who become truly righteous." 1 Those who know the Republic will remember how Plato, by patient argument and laborious logic, proves the absurdity of the old stories and arrives at this conclusion; thus reaching in the Greek way, by following his reason, what Hebrew prophets reached by a leap of the mind in a moment of revealing vision. Think, by

${ }^{1}$ Theaet. 176 . 
contrast, how many centuries it took Europe to put the dark stories of the Old Testament in their proper place. The same spirit was applied to politics, and democracy came into being, and her charter was written in words which no subsequent age need ever rewrite; in the speech which contains it Pericles claims as a peculiar quality of the Athenians, that they were never afraid of thought, but made it the basis of all they did.

The same spirit of creative intelligence was applied to the art of writing; and, though they had no specimens of prose, Greek or foreign, to guide them, within a hundred years of their first attempts, they not only wrote far better than we do (in the mere art of writing, Greece has never been surpassed), but they had discovered the essential principles of prose style, and had begun to discuss what rhythms were suitable to it. (Till Professor Saintsbury wrote his History of English Prose Rhythm, we had not conceived that there was such a problem at all.) The same spirit was applied to history, and Thucydides wrote that account of the Peloponnesian War which caused Macaulay to say: "I finished Thucydides after reading him with inexpressible interest and ad- 


\section{THE CASE FOR GREEK}

miration. $\mathrm{He}$ is the greatest historian that ever lived." 1

It was applied to morals, and the Greek cast of mind can be seen in the notion of Socrates that virtue was knowledge, that you could become a good man as you could become a good pilot or carpenter, by learning the business of using your brains. If we are aware that goodness requires also qualities of will which Socrates overlooked, still, let us respect the bold challenge to the reign of mere tradition and custom which his theory made, and remembering that our belief in education rests partly on something not unlike it, let us pass to Aristotle's criticism of Socrates and his monumental analysis of the contribution of Knowledge, Will and Habit to human conduct.

At first, as was natural, this spirit of creative intelligence produced its greatest results in the realm of man, and its scientific speculations were guesses, always ingenious, often brilliant, but unconfirmed by experiment, and unsupported by evidence. With Aristotle this changed. He conceived the notion of mapping out the field of

${ }^{1}$ Trevelyan, Life of Macaulay, p. 689: the date is Feb. 27, I 835 ; a year later Macaulay pencils in his edition of Thucydides, "I am still of the same mind." 
knowledge, assigning each subject to its proper science, and founding his conclusions on masses of ascertained and sifted fact. (His own work on politics was based on the study of 158 constitutions.) In this way he was the founder of the modern scientific method, and the precursor of that first great attempt to know the world, which the Alexandrians made in the third and second centuries B.c., and which our nineteenth century resumed with more knowledge and more instruments to use it, but not with more eagerness, laboriousness, or energy.

Here we have one reason why Greece has acted as a ferment, a stimulant, to ages and individuals who rediscover her, from the Renaissance to our own day. It is not surprising. Some ages, from historical circumstances, and all people individually, from the necessities of education, are brought up to certain habits and institutions. Then they come across thought, and the chains of their servitude fall away, they are free from the rule of use and wont. The world is no longer a cage where they are born to captivity, but a house which they can remodel and rebuild. The phrases and forms of society are seen not to 
be adamant or iron; they have in their hands a power which can reduce all things to their constituent elements, separate the rotten from the sound, and, if they wish, create the world anew. This power is thought, the great solvent, the great creator. And because Greece is thought incarnate Sir Henry Maine could say, that nothing moved in the world which is not Greek (he had forgotten that there was such a place as Palestine), and the Socialist Hoffmann in the Prussian Lower House in I9I6 could say, less picturesquely but more truly, "all modern European nations still suck their nourishment from things Greek." 1

But it is said: We grant that the Greeks were a great people: still after all they were often wrong; it was not their fault but that of their age. A modern text-book is a safer guide than Plato or Aristotle, for it can contain their wisdom and avoid their errors. We respect their performance and recognise that it was wonderful for their time; but it is absurd to use them when we can get modern books, as it would be to use a velocipede in the age of the motor car. "Hellas," as Sir H. H. Johnston says, "once held high the lamp by the light of which humanity endeavours

${ }^{1}$ Quoted in the New Statesman, Ap. 22, 1916. 
to peer into the mystery of the universe. Let us by all means be grateful historically, but all these facts could be stated in a few hours' reading or lecturing, The philosophy of Plato-a thinker who knew nothing of the earth but a small bright patch round the Eastern Mediterranean, who knew nothing of Japan and China, India, America, or the British Isles, nothing of the true relations between the earth and the sun, nothing as to the main facts of astronomy, physiology, psychology, human anatomy, and the laws of nature in general -is scarcely worth our attention to-day except as an interesting point in the progress of human thought. Can we seriously go to Aristotle for accurate zoology, or even to Thucydides and Xenophon for accurate history?" 1

This criticism is plausible: but a very little thought will reveal its hollowness. Apply a similar argument to the Bible; and we may find ourselves rejecting Isaiah and $\mathrm{S}$. Paul as thinkers who knew nothing of the earth but a small bright

${ }^{1}$ Nineteenth Century, July r9i6. The doubts raised, as to Sir H. Johnston's competence to speak on this subject, by his extraordinary idea that we cannot "go to Thucydides and Xenophon for accurate history," are not quieted by his assurance that he is "personally greatly interested in Hellenistic (sic?) studies." 


\section{THE CASE FOR GREEK}

patch round the Eastern Mediterranean, and who knew far less of the main facts of astronomy, etc., than Plato, and are therefore, on Sir H. Johnston's principles, 'scarcely worth our attention.' Apply it to Chaucer and Shakespeare: they too will be blotted out for their ignorance of natural science, and their scanty acquaintance with geography. The fallacy is obvious. It is quite true that the scientific books of yesterday are obsolete to-day, because they deal with a subject where knowledge is continually advancing, and our opinions change with its advance. It would therefore be absurd to use the Historia Animalium as a text-book in zoology; no schoolboy or undergraduate reads it, nor has it ever been proposed that they should. But it is different with books whose greatness lies in their ideas, or their attitude to life, or their picture of human nature. Man changes little with the centuries; he eats and drinks, marries and is given in marriage, as in the days of Noah, as in the days of the Son of Man. In himself and in the states he founds, much the same problems and crises arise in all ages, for they grow out of an unchanging human nature, of which the writers of the Bible, and Aristotle, and Shakespeare knew as much, to put it mildly, as 
the cleverest writer of to-day. Look back at the quotations cn page $90 \mathrm{f}$; ; have the discovery of the Antipodes or the advances of science antiquated them?

Sir H. Johnston's fallacy springs from the idea that education is acquisition of knowledge; and no one has more concisely stated the objection to this than a Greek thinker of the sixth century в.с. $\pi о \lambda v \mu a \theta_{i a}^{\prime} \nu^{\prime} o \nu$ ov $\delta \iota \delta a ́ \sigma \kappa \epsilon l$, said Heraclitus, "masses of knowledge do not instruct a mind." If the sole object of education was to impart facts, then a modern text-book on morals might be more useful than Aristotle, though its moral teaching would probably be feebler, and though it might possibly contain more cardinal errors. But, while education must impart the knowledge necessary for the conduct of life, its prime end is not $\pi o \lambda v \mu a \theta i a$ but the development of vous, the training of an inquisitive, acute, industrious, patient, truth-loving mind, which knows what facts are essential and what are unimportant, when a thing is proved, and when it is not. When this has been done, we have something which knows how to collect facts, and when collected, how to use them. Without it we are like men who try to carpenter before they have 


\section{THE CASE FOR GREEK}

got tools. It is not developed by studying textbooks, but by living with the great men who have had a portion of this spirit, and who inspire it. It is the prophet's mantle, which only the prophet can bestow. In education, as in life, the deepest impressions are made on us by contact with great personalities.

Anyone who looks back on his school-days, recalls a long succession of teachers. Some were full of knowledge, some were able to impart it; some were neither. But few really influenced us, and those, most people would say, were the men with personality. We remember them, for they gave us not knowledge, but something rarer, more fertile, more unforgettable-a way of looking at life. If we could have our education over again, we should ignore the others and go back to them, for they are the real educators. Facts we can pick up for ourselves, but an outlook on life, a spirit in which to interpret and face it, cannot be had from manuals, but only from living personalities or from books into which such personalities have passed. That is why, as any teacher knows, it is far more profitable for a student, say of philosophy, to read, for instance, Kant, with all Kant's obscurity, errors, and preposterous language, than to read a modern 
book on him, which has eliminated the errors, and purified the language, but in which the personal touch of the master is no longer felt. In the one case he has met and known a genius, in the other he has not. That is why the Greeks maintain a hold on education. With a clearness of thought and expression, very foreign to Kant, they offer us many things-unsurpassed achievements in art and literature, the example of a rich, complete life, the spectacle of reason incarnate, reason in religion, politics, philosophy, history, letters, life. They knew less than we, but they had more of the spirit which begets knowledge; otherwise they could not have brought, as they did, light out of darkness. And what is equally important, they present knowledge not as a dull necessity, but as an ideal, beautiful, imaginative, passionate quest. If we want vov̂s rather than $\pi o \lambda v \mu a \theta_{i}^{\prime} a$, where shall we find it purer than in them?

Let us evoke the most famous of them ; for in popular thought Socrates is generally so regarded; and certainly to know nothing of him is to ignore a man who is in the world of thought almost what Christ is in the world of religion. The scene is a market-place, and an elderly man is the centre of 
a group, chiefly young and well-to-do. The conversation shifts over a wide field, from the belief in immortality to the qualities of a good general, or the means of making men patriotic, but it tends to come back to a discussion of general ideas-what are righteousness, justice, temperance, courage, love? And it is always conducted by question and answer, Socrates leading his audience round to the conclusion which reflection shows them to hold. It is a method which he calls, from his mother's profession, intellectual midwifery. At this moment Socrates is talking to a rather pompous priest, who is arguing that ' religion' compels him to prosecute his father for leaving a murderer bound hand and foot to die in a ditch from neglect. "And what is religion, Euthyphro?" Socrates says. Then follow various definitions, as Euthyphro is driven from position to position by the searching enquiries of his friend. "It is doing what I do, prosecuting anyone guilty of murder or similar crimes." "It is what is dear to the gods." "It is attention to the gods, serving and ministering to them as our servants minister to us." But one by one the definitions, as Euthyphro says, "on whatever ground they are rested, seem to turn round and walk away from us" before that remorseless 
dialectic. After all, how many people could give a satisfactory account of what 'religion' really is?

Why is this little society so important in the history of thought? Why is it possible to compare the influence of Socrates in his own particular sphere with that of Christ in religion-Socrates who spent his life in trying to discover, by question and answer, the real meaning of justice, virtue, courage and other abstract terms?

Partly it is the personality of this Greek who charged himself with the mission of preaching virtue to men and the duty of 'improving their souls,' who spent his life in giving his message, refused to modify it when it was unpopular, and for its sake went so willingly to death; partly it is the message itself, partly the manner in which it was delivered.

One great danger of the modern world is our susceptibility to the general ideas that float around us, thick as bacilli, in the air, that pass our lips so often, and are so influential in our lives, that we use so readily without ever having analysed what we really mean by them. We are hardly conscious of this danger, though the example of a great nation on the Continent, besotted and maddened by false ideas, might have brought it home to us. 


\section{THE CASE FOR GREEK}

Yet every newspaper besets us with such conceptions, recommending, dissuading, praising, vilifying ; novels, poems, essays, politicians, preachers, economists, educationalists, advertisers, reformers of every kind press their special notions upon us; and it is equally difficult to accept or reject them. Fifth century Athens suffered a similar invasion of idea bacilli, and Socrates, who first fully divined their significance and danger, was also the first to devise a treatment for the disease, a habit of scepticism, in the original and proper meaning of the word, of reasonable and not captious criticism. His remedy has never been superseded or improved upon; it remains our only resource to-day, when we are attacked. How salutary a presence he would be in our midst: how many questions he would put to modern Europe! He would ask the Sinn Feiners what they meant by nationalism, and the Chambers of Commerce what 'education' is, and the Daily Herald what 'socialism' and 'democracy' are, and the signatories of the science manifesto whether, when they spoke of 'science,' they meant 'physical science' or 'scientific method.' He would try to discover the exact ideas in men's minds when they talked of Progress, Freedom, Religion, Efficiency and other familiar phrases, and 
to see how far these ideas were intelligible and consistent. And he might well find with our politicians, poets and working men, as he found in Athens, that they often "believed themselves to be wise in things in which they were not wise." 1

Note too something more about his method. General ideas do not go unquestioned among us; the Daily Mail replies to the Daily News, the Times to the Kölnische Zeitung, Sir E. Ray Lankester to the upholders of the classics, our party politicians to one another. But the methods of Socrates are not those of our party politicians or journalists. For one thing he dislikes long speeches. ("Protagoras," he says to one of these disputants, "I have a wretched memory, and when anyone makes a long speech to me I never remember what he is talking about." 2) He professes to be unable to follow dogmatic persons who "slip away from the point, and instead of answering make a speech at such length that most of the hearers forget the subject at issue." 3 (This would be a not unfair description of many leading articles and political harangues.) His own method is question and answer, moving slowly from point to point, leaving
${ }^{1}$ Plato, Apol. 22.
${ }^{2}$ Id. Protag. $33+$.
${ }^{3}$ Ib. 336 . 
no inch of ground unexamined, and in consequence running far less risk of overlooking truth than the writer or speaker who discharges his views on the public without fear that they will be scrutinised in detail. $\mathrm{He}$ is the father of cross-examination. And who doubts that the method of Socrates and not of the leader-writer is most likely to guide us to truth, if we really wish to find it?

Then, and here again he differs from some politicians and journalists, he is never rude and never loses his temper. $\mathrm{He}$ is the first and most perfect model of a type that has never been common in the world, the courteous controversialist. One day when he was arguing with a sophist who had maintained that Might is Right, his opponent, instead of answering, said: "Tell me, Socrates, have you a nurse? Because she lets you snivel instead of wiping your nose when it wants it" ; and then, after a long speech, broke off the argument. To which Socrates' only reply is: "Really, my dear Thrasymachus, you have involved us in a big argument: and are you going off without having sufficiently instructed us and ascertained for yourself whether your views are right or not?" I And Thrasymachus, for mere shame, has ${ }^{1}$ Republic, 343, 344. 


\section{I 2}

to stay while the enquiry proceeds. In all the recorded conversation of Socrates there is not a word of discourtesy or bitterness, nothing that could muddy the wells of discussion by introducing personal feeling, for he knew that wounded pride and petty irritation, even more than real division of opinion, separated men and prevented them from finding the common truth. Not many controversialists remember that.

And this brings us to a further point. It may be urged that there is something negative and sterile in this Socratic spirit, that it is too critical and analytic; that it has the fault of pulling popular ideas to pieces and leaving nothing in their place; that it sweeps and garnishes the house of the human mind, but leaves it empty for seven devils worse than before to enter in and dwell there.

This is a just attack on the critical spirit, but not on Socrates, who added to a hatred of lies a passion for knowledge. Anyone with a spark of intellectual interest will find it fascinating even now to ask what ' justice' or 'liberty' or 'friendship' are, and how far good conduct depends on knowledge; though in such enquiries we are sailing over charted seas and following the courses of 
many predecessors. But how far greater was the delight to the companions of Socrates in days when the questions had never been asked before, setting out like Elizabethan adventurers over unknown waters on the most romantic of all quests, to discover the New World of moral and intellectual ideas. We catch something of their excitement in the words of Phaedrus: "What is the secret of good style?" says Socrates; "shall we ask Lysias and others?" - "Shall we ask?" he replies. "Why, what should one live for, Socrates, unless it be such pleasures?" 1

Words like these remind us that Socrates was no mere cold critic; and still more striking testimony is borne by a brilliant, volatile politician of the day, who goes on, after some comments, in the candid Greek way, on the unattractiveness of Socrates' appearance: "mere fragments of you and your words, even at second hand, and however imperfectly repeated, amaze and possess the soul of anyone who hears them. . . I I have heard Pericles and other great orators, and I thought that they spoke well, but I never had any similar feeling; my soul was not stirred by them, nor was I angry at the thought of my own slavish ${ }^{1}$ Plato, Phacdrus, 258. 


\section{4 CLASSICAL EDUCATION}

state. But this Marsyas has often brought me to such a pass, that I have felt as if I could hardly endure the life which I am leading; and I am conscious that if I did not shut my ears against him, and fly as from the voice of a siren, my fate would be like that of others-he would transfix me and I should grow old sitting at his feet. For he makes me confess that I ought not to live as I do, neglecting the wants of my own soul. And he is the only person who ever made me ashamed, which you might think not to be in my nature, and there is no one else who does the same. For I know that I cannot answer him or say that I ought not to do as he bids, but when I leave his presence the love of popularity gets the better of me. And therefore I run away and fly from him, and when I see him I am ashamed of what I have confessed to him. Many a time have I wished that he were dead, and yet I know that I should be much more sorry than glad if he were to die." 1

Socrates made Alcibiades confess that "I ought not to live as I do, neglecting the needs of my soul." In the heart of this ironic critic of current ideas, this courteous disputant, this cautious searcher Plato, Symposium, 2 I 5 f., tr. Jowett. 
after truth burns the same spiritual passion which consumed Isaiah or S. Paul. Only, as a Greek, he approaches his goal through the intellect, as they approached it on a tide of religious emotion. To know him is to know the greatest incarnation in history of the spirit of thought, keen-eyed, patient, ardent, moralised; and if we consider how often in the twentieth century we fail to think out the underlying principles of our beliefs or actions, how often we are victimised by unanalysed ideas, how indifferent we are to knowledge, how careless of truth, how ready to lose our temper and say things which turn discussions into partisan quarrels-then we shall see how much we have still to learn from Socrates.

Let us take another example, earlier in time than Socrates, less famous than he, but full of the same spirit. A man, apparently in perfect health, falls to the ground with a sharp cry, and lies there rigid and pale. Then he flushes dark red, his fingers twitch open and clasp again ; convulsions shake his arms and legs and face, his teeth close with a snap and foam trickles through them, he perspires profusely. In a few minutes he begins to come to himself, and then falls into 
a deep sleep. There is no visible explanation of these sudden fits; they may be rare and have no permanent effect, they may be frequent and pass into a darker eclipse of the reason. We recognise the symptoms of epilepsy, but if we had lived before the conception of science and of natural law had dawned, when all unusual things seemed magical, would it be surprising if we had thought them uncanny and supernatural? We know that the Jews as late as our own era supposed epileptics to be "possessed with a devil." Now hear a Greek of the fifth century on the subject. He is attacking the prevalent view that this is a 'sacred disease,' sent by god and to be cured by incantations: "I, however, do not consider that the body of man is polluted by god, the most perishable by the most holy of things; for even if it were defiled, or in any way affected by something else, it would be likely to be purified and sanctified rather than polluted by god. . . . This disease seems to me to be no more divine than the rest; but it is as natural as all other diseases, and has a cause for all its symptoms; . . . it has the same origin as all other diseases, and is curable just as they are, except where from length of time it is confirmed, and has become too strong for the 
remedies administered. In origin it is hereditary like all other diseases. For if a phlegmatic person be born of a phlegmatic, and a bilious of a bilious, and a phthisical of a phthisical, and a hypochondriac of a hypochondriac, what is to hinder it from happening that where the father and mother were subject to this disease, certain of their offspring should be subject also? Another great proof that it is in no way more divine than any other disease is, that it occurs in those who are of a phlegmatic constitution, but does not attack the bilious. Yet, if it were more divine than the others, this disease ought to attack all alike, and make no distinction between the bilious and the phlegmatic. The brain is the cause of this complaint, as it is of all the other chief diseases, and in what manner I will now plainly declare. . .." And again : "This so-called Sacred Disease arises from the same cause as the others, namely, those things which enter and quit the body, such as cold, the sun and the winds, which are ever changing and never at rest. And these things are divine, so that there is no necessity for making a distinction, and holding this disease to be more divine than others, but all are divine, and all human; each has its own peculiar nature and power, and none is beyond our 
control or skill. And most of them are curable by the same forces as produced them." 1

I have only quoted a small fragment from his essay, and given no idea of his minute enumeration of the symptoms, and the acute argument by which he supports his views; but is not his attitude cool, lucid, reasonable, observant, inspired by the very soul of science? Could the twentieth century, however it modified his conclusions, improve his spirit and method? And is there not something unique in the race which 400 years before Christ thus turned the light of reason into the black darkness of mystery that surrounded man?

"The clear recognition of disease as being . . . a process governed by what we should now call natural laws ... led to habits of minute observation and accurate interpretation of symptoms, in which the Hippocratic school was unrivalled in antiquity, and has been the model of all succeeding ages, so that even in these days... the true method of clinical medicine may be said to be the method of Hippocrates." 2 Here is an extract

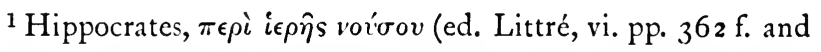
394). In parts I have used the Sydenham Society translation. ${ }^{2} \mathrm{Sir}$ T. C. Allbutt, Article on "Medicine," p. 42, Encyclopaedia Britannica. 


\section{THE CASE FOR GREEK}

which shews not only his acute observation, but also his literary gift: "But such persons as are used to the disease, know beforehand when they are about to be seized, and flee from men; if their own house be at hand, they run home, but if not, to a lonely place, where as few persons as possible will see them when they fall, and they immediately cover themselves up. This they do from shame of the affection, and not from fear or from religious reasons, as most people suppose. Little children at first fall down wherever they may happen to be, because they are not used to the disease. But when they have been often seized, and feel its approach beforehand, they run to their mothers or to any other person they know, from terror and dread of the affection; for they do not know yet what it is to be ashamed." 1 Could anything be more moving than this? It is like an extract rather from a tragedy than a medical treatise.

To the same Hippocrates is attributed the noble physician's oath which, with small changes, is still used in some of our medical schools: "I swear by Apollo the physician, and by Asclepius, and Health, and All-Heal, and I call all gods and

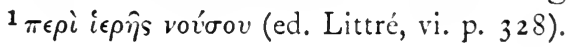


goddesses to witness that, according to my ability and judgment, I will keep this Oath and this Bond - to reckon him who taught me this Art equally dear to me as my parents, to share my substance with him, and in the hour of his need impart what he requires, to look upon his offspring in the same footing as my own brothers, and to teach them this art if they wish to learn it, without fee or stipulation. . . . I will follow the system of regimen which, according to my ability and judgment, I consider for the benefit of my patients, and abstain from whatever is deleterious and mischievous. I will give no deadly medicine if asked, nor suggest any such plan; so too, I will not produce abortion. With purity and with holiness I will pass my life and practise my Art. . . I Into whatever houses I enter I will go into them for the benefit of the sick, and will abstain from every voluntary act of mischief and corruption. . . Whatever in my professional practice or outside it in the life of the world I see or hear, which ought not to be spoken of abroad, I will not divulge, considering that such things should be kept secret. While I continue to keep this Oath unviolated, may I be allowed to enjoy life and the practice of the art, respected by all men, in all times. But should I 
trespass and violate this Oath, may the reverse be my lot." 1 It is with men like the writer of this that we shall live if we study Greek ; can we wish for or find better company in the world of the intellect?

We shall come back to the Greeks later ; meanwhile we have glanced at some of the arguments for their place in education. We have seen that modern Europe is rooted in the culture of the classical world; that in studying this we become at the same time acquainted with a superb literature and a brilliant national life, and that, in particular, we are immersing ourselves in that spirit of free enquiry and rational explanation which is the oxygen in the air of the modern world, and yet never has been purer and more concentrated than in Greece. Perhaps too much stress has been laid on this point and too little said of Greek literature. But the outside world, while willing to admit the merits of the latter, is apt to think, illogically enough, that otherwise Greece is out of date. I have tried to show how false this view is, how living is her spirit, and how potent those

${ }^{1}$ Ed. Littré, vol. iv. p. 628 f. Sydenham Society translation, with some changes. 
'rigorous teachers,' of whom Matthew Arnold writes, that they

Seized my youth, And purged its faith and trimmed its fire, Showed me the high white star of Truth, There bade me gaze, and there aspire.

Of course it is quite possible to dispense with the Greeks. It is quite possible to go through life without reading Shakespeare. It is possible even to go through it without reading the Bible; there have been great religious books since it was written, and great saints who have caught and in some measure reproduced its spirit. Yet the knowledge of all of them would not really replace the great fount and original of our religion. Something the same may be said of Greek literature, which is the Bible of the world of thought. ${ }^{1}$

${ }^{1}$ A fuller discussion of our debt to the Greeks will be found in my book, The Greck Genius and its Meaning to us. 


\section{CHAPTER IV}

\section{THE CASE FOR LATIN}

Graeci praeceptis valent, Romani exemplis. Quintulias.

Now let us turn to Latin, and demand the credentials which have gained it admittance to our education. At first we are puzzled to find them. There is no intellectual supremacy here; no spirit of living reason moving through and ordering human life. It is a fine literature, but there are finer in languages yet spoken. It has three poets who are in the first rank, and it would be difficult to match Horace's literary art and genial commonsense ; but the rest of Latin poetry is rarely more than excellent verse. "If we were without the four supreme poets, we should rise from the reading of Latin Poetry with the sense that a puissant and energetic people had deliberately, for six centuries, set themselves to prove that poets could be made as well as born-and had 
just failed." 1 Rome has no philosophy worth the name, no first-hand original thought; and except Caesar, her historians, though great writers, are partisan and somewhat uncritical. If we have not read Tacitus and Cicero, we hardly realise what man can achieve both in concentrated epigram and close-packed thought, and in ample, rich rhetoric, "like a spreading conflagration enveloping and devouring the land"; ${ }^{2}$ but the other Roman prose writers may be matched in more recent literatures. It would be a literary loss never to know that gift of throwing a thought into a few words, which is the peculiar property of Latin, and which has made it the great language for inscriptions. Monumental phrases like the following are typical: Solitudinem faciunt, pacem appellant (an unfair description of Roman dealings with subject races). Feminis lugere honestum est, viris meminisse. Principes mortales, rempublicam aeternam esse. Breves et infaustos populi Romani amores (on the death of Germanicus). Deorum iniurias dis curae (Tiberius' reply to an obsequious senator who wished a contemporary to be prosecuted for taking in vain the name of the deified

${ }^{1}$ H. W. Garrod, A Book of Latin Verse, p. 24.

$2 \pi \epsilon \rho i \ddot{v} \psi o v s$, c. 12. 
Augustus). Magis alii homines quam alii mores. Volunt reprehendi dum conspici (on fashionable people). Ecce res magna habere imbecillitatem hominis, securitatem dei ${ }^{1}$ (of the Stoic). No other literature can shew language cut in such high relief, and to be ignorant of Latin is not to know what the human mind can achieve in expression. Still, this by itself could not justify the place of Latin in education.

German critics have said that the value of Roman literature is that it has been the vehicle which conveyed Greek ideas to the world; and though this statement is more discreditable to the critics than to the Romans, it contains a particle of truth. The Romans themselves are quite frank in the matter. All their literary forms and metres ${ }^{2}$ come from Greece, large masses of their poetry are translations or close imitations of Greek originals. They took their thought, art, and, as far as civilisa-

1 "They make a solitude and call it peace." "Women should mourn, men remember." "Emperors are mortal, the state is eternal." "The darlings of the Roman people are brief-lived and ill-starred." "Wrongs to heaven are heaven's affair." "A change of men but not of morals." "Indifferent to blame, if they can attract attention." "It is a great thing to be as weak as man, as untroubled as God."

2 Except Saturnian and the Versus populares. 
tion rests on these, their civilisation from Greece : and in the golden age of Rome, when Horace is asked advice by some young tragic poets, he says:

My friends, make Greece your model when you write, And turn her volumes over day and night. ${ }^{1}$

It is as though all English art came from France, while English literature was either a translation or an imitation of French.

Why, then, do we study Latin? Some of the reasons are given by Cicero in a passage where he sums up the excellences of Greece and Rome, and declares the grounds on which his country has a claim to be considered great. "Our mastery of character and of national life, of the family and of the home is far higher and nobler than theirs; our ancestors devised for the state an indubitably better system of laws and institutions. Or again, take the art of war: and think what Rome has achieved in individual heroism and even more in collective discipline. In these achievements which depend not on literary gifts but on character, neither Greece nor any other people can be com-

${ }^{1}$ A.P. $268-9$ (tr. Conington).

Vos exemplaria Gracea

Nocturna sersate manu, z'ersate diurna. 


\section{THE CASE FOR LATIN}

pared to us. Where will you find a sense of dignity, a resolution of purpose, a loftiness of spirit, a feeling of truth and honour which can be matched with those of old Rome? In learning, in every branch of literature the Greeks are our masters; and victory is easy in an undefended field." 1 In fact he allows intellect to Greece, but claims character for Rome. Shelley has expressed the same thought with a poet's imagination: "The true poetry of Rome lived in its institutions; for whatever of beautiful, true and majestic, they contained, could have sprung only from the faculty which creates the order in which they consist." 2 It is just here where Greece differs from Rome. When we think of Greece, we think of Socrates, Plato, Thucydides, Euripides, not of Alcibiades, Themistocles or Eubulus; and of Pericles himself less as a statesman than as a political thinker. When we think of Rome we think of Cato or Augustus or Pompey or Caesar-and of the last rather as a statesman than as a writer; only in the second place do we think of Horace or Vergil or Livy. What we value in the achievements of Greece is what is written in her literature; what we value in the achievements of Rome is what was
${ }^{1}$ Tusc. I. I. 2.
2 Defence of Poetry. 
done outside her literature. For that literature is not directly concerned with the big problems which Rome had to solve; only at times do its poets complain of their pressure or triumph in their solution, whereas in Greece the poet is as much in the fighting line as the statesman. It is not the fault of Vergil and Horace; the difficulties of their age were material rather than spiritual, and the business of poetry is not with material things. But the fact deprives Roman literature of the peculiar interest of the literature of Greece.

If either Greek or Latin had to disappear from education, every lover of literature would prefer that Latin should go. For its literary masterpieces, for its sane and steady view of life, for its intellectual inspiration and stimulus, Greece is unmatched and unmatchable: the Greek temper is so necessary to us, yet so alien from us, that we require it as constitutions of a certain habit require iron. "Greek," as Mr. J. W. Headlam says, " is a medicine, it is not something that belongs to us, it is something to which we go to supplement, correct, and change what is native and indigenous." But to drop either Greek or Latin would be to lame classical education, to cut off one of its two legs. They are complementary; each has a 
deficiency, and each supplies the other's deficiency ; as the Romans knew, who took their civilisation from Greece, and the Greeks knew, who glorified the stability of the Roman empire in which they were content to live. If nothing moves in the world but what is Greek, it is almost true to say that nothing stands but what is Roman. Combine the two and you have the strength of Rome without its hardness, the glory of Greece without its instability, and (what is important for education), you have perfect models of two sides of human nature, which in union go to make the perfect man and state.

Before Rome became mistress of the world, Europe had never found a way of combining liberty with order. Greece had propounded a theory of politics, but had been singularly unsuccessful in creating a stable, large-scale state-the imperial power of Athens lasted sixty years, that of Sparta and of Thebes even less. Such is the record of Greek political achievement. The empires of Alexander's successors were equally unable to discover the secret of permanence. But while these empires and monarchies successively formed and broke up, as rapidly as the eddies in a weir pool come into being and dissolve, a small town in 
Italy was leading a struggling existence in the middle of powerful tribes. Sometimes she was victorious, sometimes she bought off the enemy, once or twice she was almost destroyed. In the end, after continuous warfare, she gained a precarious supremacy in South and Central Italy, and turned her eyes across the seas. 'Two hundred years more of fighting were added to her wars in Italy, and she emerged practically the mistress of the world, with a stronger organisation and sounder statecraft than had yet been known.

In these early struggles a character was formed that never lost traces of its origin. It is betrayed in the favourite adjectives: fortis, strenuus, constans, diligens, firmus, verecundus, castus, prudens, gravis, assiduus, sedulus (the last two reminding us of the saying, Sedendo vincit Romanus). Hard necessity taught the Roman to prize these qualities. He became brave, stubborn, honest because otherwise he would have been destroyed. He learnt the art of statesmanship and compromise, because he had either to avoid civil war or perish. He avoided vice, because there was no leisure to be vicious. He was not luxurious, because he had no means of making money. All this became a second nature to him. That is why Cicero makes his claim in 
the Tusculans. That is why Quintilian says, rather unjustly to Greece: Graeci praeceptis valent, Romani exemplis. "The Greeks tell us, the Romans shew us, how to live." That is why in poet after poet of Rome lines of a certain quality reappear. There is nothing in the sentiment or diction or style which shews them to be the work of any particular writer. They bear a common stamp, and might have come from one mint. They bear the stamp of the Latin genius.

Vitaque maniipio nulli datur, ommibus usu (Lucretius).

Noenum rumores ponebat ante salutem (Ennius).

Nil conscire sibi, nulla pallescere culpa (Horace).

Non fuit exuviiis tantis Cornelia damnum;

Quin et erat magnae pars imitanda domus (Propertius). Bene non poterat sine puro pectore vivi (Lucretius).

Virtutem videant intabesiantque relicta (Persius).

Moribus antiquis stat res Romana virisque (Ennius).

Propter vitam vivendi perdere causas (Juvenal). ${ }^{1}$

1 "Life is given to all to use, to none to have and hold.' "He did not set what men said, before the safety of the state." "To have no guilty secrets, no sin at which we turn pale." "Cornelia was no hurt to these high achievements; nay, she was a pattern in the great house of which she was a child." "Men could not live well without a pure heart." " Let them see virtue and pine that they have deserted her." "The state of Rome stands by its ancient manners and its men." "For the sake of life to lose what makes life worth living." 
These lines are taken from authors so diverse in time and character as Horace, Lucretius, Ennius, Persius, Juvenal, Propertius; yet except for some peculiarities of diction and metre they might be by a single writer. The common characteristic is a deep sense of something which perhaps we can best express by the word 'character,' a deep sense, not of the brilliance and glory of life, but of its tremendous possibilities for achievement and failure. They are distinctively Roman. There would be no difficulty in multiplying such lines indefinitely, or in finding sentences in prose which breathe identically the same spirit. Non votis neque suppliciis muliebribus auxilia deorum parantur; vigilando, agendo, bene consulendo prospera omnia cedunt; ubi socordiae te atque ignaviae tradideris, nequicquam deos implores. ${ }^{1}$ No one could mistake the spirit of any of these quotations for Greek; they are somehow of a different cast. Greece has indeed done more for morals than any force except Christianity, but she has done it by appealing to

${ }^{1}$ Sallust, Cat. c. 5 2. "The help of heaven is not won by vows and womanish prayers; all success is the reward of watchfulness, vigour, wise counsel; if you abandon yourself to indifference and indolence, you will ask the help of God in vain." 
the reason, by making men think. Her yvêu are generally thoughts on life rather than direct moral precepts. But the Roman maxims are direct injunctions, as peremptory and practical as the Ten Commandments, the orders of a commander-inchief on the battlefield of life.

There we have one of the reasons why Latin is so valuable in education. Glance again at the quotations on the preceding page, and think whether this is not the temper which we should wish to create in the youth of a nation, on whom a task not unlike Rome's is laid. Can we find more vivid, more trenchant, more memorable expressions of a heroic and imperial spirit? And can anyone fail to profit by knowing a literature which is full of such sayings and becoming a familiar friend of the men who made them and the nation whose character they express. Greek takes us into the world of thought; in Latin we live with a heroic race,

The commonwealth of kings, the men of Rome.

(Hero is not a word, somehow, we should use of the great Greeks, though no Roman lived and died more nobly than, for instance, Socrates.) Like Aeneas in the lower world we move among 
illustres animae, splendid souls; Cincinnatus fetched, like a Boer farmer, from the plough to be chief magistrate of Rome; Valerius, who, dying as consul, did not leave enough money to pay for his funeral; Regulus, refusing to be exchanged for Carthaginian prisoners, and himself opposing it in the Senate, because "they are young and valuable generals, while I am an old and broken man," " and going back to Carthage' to torture and death; Brutus, grimly handing his two sons over to execution because they had conspired against the state; Aelius Tubero, "who was a marvellous honest man, and did more nobly maintain himself in his poverty than any other Roman; for they were sixteen persons all of the house of Aelii, very near akin one to the other, who all had but one little house in the city, and a small farm in the country, wherewith they entertained themselves, and lived all together in one house, with their wives and many little children." 2 Consider how the Senate greeted the consul, who, chosen by the

${ }^{1}$ Cicero, De Off. $3 \cdot 26$.

2 Plutarch, $V$. Acm. Paulli, c. 5. (The translations from Plutarch are taken with a few corrections from North, who is delightful, if not verbally accurate; his translation of the Liees is published in the Temple Classics.) 
democracy against their will, had thrown away their army, not with recriminations, but with thanks, "because he had not despaired of the state." Remember that earlier picture, when the Gauls took Rome and " the honourablest old men of the city had not the heart to forsake the city: but putting on all their most holy robes and vestments, did vow, and as it were willingly sacrifice themselves unto the fortune that should befall them for the safety of their country. And using certain words and prayers which their chief pontiff Fabius had taught them, they went even thus apparelled in to the great market-place, and did sit them down there in chairs of ivory, expecting the good will and pleasure of the gods what should become them. . . . Where when Brennus saw the ancient senators set so gravely in their chairs, who spake never a word, nor offered once to rise, though they saw their enemies come armed against them, neither changed countenance nor colour at all, but leaned softly on their staves they had in their hands, seeming to be nothing afraid nor abashed, and looked one upon another, he marvellously wondered at it. This their so strange manner at the first did so damp the Gauls, that for a space they stood still, and were in doubt to come near to 


\section{I36 CLASSICAL EDUCATION}

touch them, fearing lest they had been some gods." 1

It is worth while looking more closely at one of these makers of Rome.

First let us hear his character baldly told by a historian. "His force of intellect and character was such, that he must have made his name in whatever station of life he had been born. He possessed every accomplishment for the successful conduct of public and private life. He was equally at home in city or country life. . . In war he distinguished himself in many fights by his great personal courage, and when he rose to high office, he proved himself a consummate general. In peace, if some legal question had to be settled, he was the most expert of advisers, and if a case had to be pleaded, the most eloquent of speakers. . . . He made many speeches in defence of himself and of others, many against others ; for he wore down his opponents, not only by accusing them but by pleading his own cause. Indeed he was the author and the object of too many quarrels, and it is difficult to say which were severer, his onslaughts on the aristocracy or their attempts to crush him. No doubt his temper was harsh, his tongue bitter ${ }^{1}$ Plutarch, $V$. Camilii, c. 2 1. 22. 
and unreasonably free. But his integrity was inflexible, his spirit unseduced by vice. Influence and wealth he despised. His endurance of toil and danger, his abstemiousness, shewed a constitution of iron, which even old age, that subdues all things, failed to break. In his eighty-sixth year, being on his trial, he pleaded and composed his own speech; in his ninetieth he impeached S. Galba before the people." ]

Now let us see him in the more lively colours of Plutarch.

He was red of face, grey-eyed; formidable to behold, for " in battle he would look grimly on his enemy and threaten him in a fearful, rough voice; such countenances, said he, many times do fear the enemy more than the sword ye offer them." So much for his looks.

A small farmer's son, in early life he worked with his own hands on the farm near Tusculum, where he was born, and took an interest in the local affairs of his country town. Then a friend persuaded him to go up to Rome; and there, chiefly by pleading in the courts, he made his name, held all the highest offices, commanded the Roman armies in Spain, and after being the most busy and ${ }^{1}$ Livy, xxxix. $4^{\circ}$. 
powerful man in the state, died, as the third Punic war broke out, at the age of ninety. ${ }^{1}$ That is a brief sketch of his life; a long one would give little idea of what a full life it was.

His mind was engrossed by one idea, Work. Work primarily for its own sake, apart from need for, or gain from, it ; hard labour, often menial, often unnecessary, sometimes harmful. He himself said that he regretted three things in his life: " the first, that he ever told a secret to any woman; the second, that ever he went by water when he might have gone by land; the third, that he had been idle a whole day and done nothing." $\mathrm{He}$ lived up to his maxim. As a young man he had worked on his farm with the slaves, and shared their food; on service he did a common soldier's task and then went back to assist his servant to prepare his meal; and Plutarch points out how, years later, after he had become consul, unlike most men, "he would never leave to exercise vertue, but began afresh, as if he had been a young novice in the world, and as one greedy of honour and reputation, to take as much pains and more than he did before. For, to pleasure his friends or any

${ }^{1}$ His age is disputed. Perhaps he was eighty-five when he died. The details are taken from Plutarch's Life of Cato. 
other citizen, he would come to the market-place, and plead their causes for them that required his counsel, and go with his friends also into the wars." Ten years past the age when man's strength is but labour and sorrow, a nonagenarian, he impeached Galba, and in his long life was himself accused almost fifty times.

He worked at so many things too, and knew or had theories on so many subjects. Besides his public duties, he found time to make a big fortune out of farming and finance. He even doctored his own household, writing a treatise "of physic, with which he did heal those of his house when they were sick. He never forbade them to eat, but did always bring them up with herbs and certain light meats, as mallard, ringdoves and hares; for such meats, said he, are good for the sick, and light of digestion, save that they make them dream and snort that eat them." There were few practical matters on which he was not an authority, and among his writings was a book "of the country life and of tillage, in the which he showeth how to make tarts and cakes; he would needs show such singularity and skill in all things."

Work primarily for its own self, but also for money. His maxims read like the advice on 
habits valuable for making a fortune, occasionally vouchsafed to a penurious public by American financiers, through the medium of the Strand Magazine and other newspapers. For instance, he was of opinion " that a man bought anything dear that was for little purpose; yea, though he gave but a farthing for it, he thought it too much." And congruous with this are the accounts of his financial dealings, his speculations in timber, hot springs, and sites for laundries, his agencies for the purchase, education, and sale of young slaves, his elaborately secured ventures in foreign trade, on all of which Plutarch gives interesting details. And yet his money-making was not in order that he might have means to live luxuriously. No household was more temperate or frugal than his. "He durst affirm him to be divine and worthy immortal praise, that increased his wealth and patrimony more than his father left him." And he told his son that "it was no wise man's part to diminish his substance, but rather the part of a widow."

$\mathrm{He}$ was a hard man. Hard to foreigners. It was he who day after day in the Senate, whatever the subject of debate, closed his speech with the burden, delenda est Carthago. $\mathrm{He}$ was hard to his countrymen. When he 
stood for the censorship, while the other candidates flattered the electors, "Cato contrariwise, shewing no countenance that he would use them gently in the office, but openly threatening from the rostrum those that had lived naughtily and wickedly, he cried out that they must reform their city, and persuaded the people not to choose the gentlest, but the sharpest physicians; and that himself was such a one as they needed, and among the patricians Valerius Flaccus another, in whose company he hoped to do great good to the commonwealth, by burning and cutting off (like Hydra's heads) all vanity and voluptuous pleasures." To the credit of Rome, he was elected; and then did "appraise every citizen's goods, and rated their apparel, their coaches, their litters, their wives' chains and jewels, and all other moveables and household stuff, that had cost above I 500 drachmas apiece, at ter times as much as they were worth; to the end that such as had bestowed their money in those curious trifles should pay so much more subsidy to the maintenance of the commonwealth." He was hard to himself. "Never came gown on his back that cost him above a hundred pence, and his hinds and workmen always drank no worse wine, when he 


\section{I42 CLASSICAL. EDUCATION}

was Consul and general of the army, than he did himself ; and his caterer never bestowed in meat for his supper above thirty asses of Roman money, and yet he said it was because he might be the stronger and apter to do service in the wars for his country and the commonwealth." "Of all his houses he had abroad in the country, he had not one wall plastered."

There were, however, two people in the world to whom he was not hard. "He said that he that beat his wife or child did commit as great a sacrilege as if he polluted or spoiled the holiest things of the world; and he thought it a greater praise for a man to be a good husband than a good senator. And therefore he thought nothing more commendable in the life of old Socrates than his patience, in using his wife well that was such a shrew, and his children that were so harebrained. After Cato's wife had brought him a son, he could not have so earnest business in hand, if it had not touched the commonwealth, but he would let all alone, to go home to his house, about the time his wife did unswaddle the young boy to wash and shift him. ... When his son was come to years of discretion, Cato himself did teach him notwithstanding he had a slave in his house, who did also 


\section{THE CASE FOR LATIN}

teach many other; but, as he said himself, he did not like a slave should rebuke his son, nor pull him by the ears when peradventure he was not apt to take very suddenly that was taught him ; neither would he have his son bound to a slave for so great a matter as that, as to have his learning of him."

This last anecdote shows the more amiable colours in Cato's character, and here is another to set by it. "When he was in his house in the country, he fared a little better than he did in other places, and would oftentimes bid his neighbours, and such as had land lying about him, to come and sup with him, and he would be merry with them; so that his company was not only pleasant and liking to old folks as himself, but also to the younger sort. For he had seen much and had experience in many things, and used much pleasant talk profitable for the hearers. He thought the board one of the chiefest means to breed love among men, and at his own table would always praise good men and vertuous citizens, but would suffer no talk of evil men, neither in their praise nor dispraise." After reading Cato's life, we can understand how the Romans came to do so much. A nation of men like this had a great future before them. 
These iron characters at times are harsh and terrible, but they supplied the inflexible will, which carried the Romans through defeats and disasters to the empire of the world. They explain how Rome, after losing three armies, and seeing Italy overrun, yet persisted till she brought Carthage to her knees. Her enemies were dismayed by the spirit of a nation which hung on to the end, and ' had no nerves.' "Hannibal held some Roman prisoners. . . The Senate resolved that they should not be ransomed, though it would cost but little; they wished to implant in our soldiers the determination to conquer or die. Polybius says that when Hannibal heard of this, his courage wavered, because Rome's temper in misfortune was so lofty." 1 Again, the soldiers of Marcellus were beaten ; the next day they renewed the battle, and Plutarch puts this comment on their leader in Hannibal's mouth. "O gods, what a man is this, that cannot be quiet neither with good nor ill fortune? for he is the only man that never giveth rest to his enemy, when he hath overcome him: nor taketh any for himself when he is overcome. We shall never have done with him, for anything that I see, since shame, whether he win or ${ }^{1}$ Cicero, De Off. $3 \cdot 3^{2}$. 
lose, doth still provoke him to be bolder and valianter." 1

Roman literature contains, not by any means all the human virtues, but all the virtues which make great nations. "Do not think," said Cato, rebuking the degeneracy of his own day, "that our ancestors made Rome great by their arms. . . . There were other things which made them great, industry at home, just government abroad, and a free mind in counsel, the slave of neither passion nor crime." 2 Deep reverence for the family and for the woman as mother of the family, selfcontrol, self-sacrifice, the sternest sense of duty, unrelenting determination, dauntless courage, " honourable poverty, fervent zeal for the interests of the state, noble equarimity tried by both extremes of fortune and disturbed by neither" Rome offers us examples of all these in abundance. It is not an accident that her literature has supplied so many mottoes to those English families, whose virtues recall the high courage and public spirit of the great Roman gentes; and it is by an inner sympathy between our race and theirs that Pitt in the Napoleonic wars applied to this

$$
\begin{aligned}
& { }^{1} \text { Plutarch, } V . \text { Marcelli, c. } 26 . \\
& { }^{2} \text { Sallust, Cat. c. } 52 . \text { This was Cato of Utica. }
\end{aligned}
$$




\section{I46 CLASSICAL EDUCATION}

country the lines written by Horace of his own people, who

(As on Algidus the oak

Pruned by the biting axe anew)

From wounds, from death, from every stroke

Resource and freshening vigour drew. ${ }^{1}$

Add to these the qualities which made them great rulers, observance of their word, a certain generosity and scrupulousness towards the enemy, tact and clemency to the conquered, virtues of which Plutarch's lives of Flamininus and Aemilius Paullus give splendid examples, and it is easy to understand how Augustine, while he criticised Rome, held up to the Christians, citizens of a kingdom in heaven, the pattern of what Romans had done for an earthly country. ${ }^{2}$ The pattern has its uses in our own times, when the sense of the family and the state is weak, and few people are in danger of asking too much of themselves or of anyone else. Further (and it is one of its

${ }^{1} \mathrm{Od} .+\cdot+\cdot+9$ (tr. Gladstone).

Duris ut ilex tonsa bipennibus

Nigrae feraci frondis in Algido,

Per damna, fer caedes, ab ipso

Ducit opes animumque ferro.

"De Civitate Dei, 5. I 8 . 
educational advantages), Latin at first appeals much more readily than Greek to the ordinary boy. He may change his allegiance later, but at school it is generally given to Rome. The climate of Greek literature is one we do not habitually breathe; it is for that reason all the better for us, but we must grow used to it before we can fully profit by it or feel at home in its air. And this is particularly so with schoolboys, who have no great passion to give an account of life, and are more interested in action than in thought. Indeed it is so with most Englishmen ; they would agree with Cecil Rhodes. "Referring to his pride in the Roman character, he was wont to say how much he preferred it to the Grecian type-the courage, strength and straightness of the Roman to what he called the versatility and shiftiness of the Greek, however beautiful the creations of his genius." I

Certainly we are in many ways very Roman. The trenchant moral maxims of Rome come home to us more nearly than the delicate and profound musings of Greece.

Aequam memento rebus in arduis

Servare mentem,

${ }^{1}$ Sir T. E. Fuller, Cecil Rhodes, p. $25^{8}$. 


\section{48 CLASSICAL EDUCATION}

is more to our taste and in our manner than

Who knoweth if this thing that men call Death

Be Life-and our life dying-who knoweth?

Save only that all we beneath the sun

Are sick and suffering; and those foregone

Not sick, nor touched with evil any more. ${ }^{1}$

So too, Roman statesmen are more akin to us and more intelligible than Themistocles or Pericles. Take a few passages that relate to the education, methods, and life of a Roman who ruled over our distant ancestors with success, and who in our own days would have been a Governor-General in India. "I remember," says his biographer, "he told me that as a young man he became vehemently fond of the study of philosophy, and pursued it further than a Roman of his rank should, till his mother's good sense checked his violent passion for it." 2 Then his administrative methods. "He knew the temper of the province, and the experience of other governors had taught him that little was effected by force, if it was followed by injustice. $\mathrm{He}$ therefore determined to put an end to the causes of the risings. He began with himself and his staff, and set his own house in order, a task which most men find as difficult as the government

${ }^{1}$ Euripides, fr. $8_{3} 0$ (tr. Murray).

2Tacitus, fgricola, c. 4 . 


\section{THE CASE FOR LATIN}

of the province. His freedmen and slaves had no hand in state affairs; military posts were not given on recommendations or petitions ; with him excellence was the title to trust. He knew everything that went on, without always acting on his knowedge (omnia scire, non omnia exsequi). Veniall offences were forgiven, serious ones severely punished. He was generally content with repentance, and did not always insist on a penalty. Instead of condemning offenders, he preferred to place in offices and administrative posts men who would not offend." 1 Mutatis mutandis, the picture might be that of an Indian civilian or a good school prefect.

Besides, the Roman's work in the world is our own. Like the woman in Kipling's story, the Englishman prefers men 'who do things'; now the Romans were always ' doing things,' and these deeds interest us. What achievements they are and how well worth study for any politician or elector of a great empire! Take, for instance, the problem Rome had to face in the years that followed 60 B.c. I will put it into modern language. Imagine Great Britain without our elected House of Commons, and ${ }^{1}$ Ib. C. 19. 


\section{50 CLASSICAL EDUCATION}

governed by its landed aristocracy; the democracy is represented by nine officials, with large powers of obstructing state business; the big mercantile, capitalist class is unrepresented and highly dissatisfied; hence riots and continual political intrigue. Meanwhile Britain has got by conquest a world-wide empire. She governs its various parts by generals taken from the aristocracy. There is no effective means of controlling these governors during their time of office; they have armies which they have enlisted themselves; the taxes and supplies of their provinces are in their entire control, and they have further large powers of requisitioning; they have no colleagues in their office, and no permanent officials to control them, and each governor chooses his own staff; they may have had no previous experience of government, and they have probably never seen their province before. Yet the whole management of it is in their hands, and in the absence of steam or telegraph the government at home can do very little to touch them. They cannot be prosecuted till their time of office has expired, and then they will be tried by their peers. So some of them, being conscientious men, govern well; others plunder their subjects; and one or two with wider 
aims acquire armies with a view to becoming masters of Britain. At the moment there are three of these ; they are rivals, but for the present they have patched up their difference in a meeting at Harrogate, and agreed to a division of power and a certain allotment of the provinces. The government which hates them, but has no army on which to rely, has been forced to consent ; and so, in an unstable equilibrium, the world waits uneasily for the clash which is to come.

No parallels are exact; but this not unfairly represents the state of the Roman empire in 56 в.с., when Pompey, Caesar and Crassus parted at the Baths of Lucca. A generation later Augustus had founded a government under which the world was for a space to enjoy prosperity and peace. The problem had been solved, the provinces had a stable, uniform, just and efficient administration, the central government had recovered control.

There we have a typical instance of what makes Rome so well worth our study. Her history is a succession of colossal political problems-problems of administration at home and abroad, of finance, of army organisation, of militarism and capitalism, of rural exodus and land settlement, of municipal life and colonisation, of increasing luxury and 


\section{52

sterile marriages, problems, above all, of imperial government, of frontiers, of vassal kingdoms, of an adequate civil service, of the unification of empire, of roads and postal systems, of imposing and collecting taxes. On most of these subjects there is no light from Greek history, for the Greek state was a city, and the Greek a $\rho \chi \chi^{\prime}$ a toy empire - very different from our world-wide states. We must go to Rome for our lessons. To govern peoples who differ in race, language, temper and civilisation; to raise and distribute armies for their defence or subjection; to meet expenses civil and military; to allow generals and governors sufficient independence without losing control at the centre; to know and supply the needs of provinces two thousand miles from the seat of government, and that without the assistance of telegraph or railway, with horses and sailing ships as the swiftest means of transport; in a word, to organise and administer the Roman empire, is a work as fascinating to study as it was difficult to achieve. And then, the fall of this power-its administrative, military, financial collapse. History has no other instance to shew of the destruction of a highly civilised and highly organised empire, for those who watch her skies for signs of the times. 
Latin then stands in our education partly on linguistic grounds, partly on the heroic characters in its history, on the interest of its political and imperial problems, and on the capacities of its people for government; and it is doubly recommended because its genius is complementary to that of Greece. Of the two limbs of the classical education it can be easiest replaced, if we are willing to sacrifice the advantages just mentioned, and with them a full knowledge of the nation that, more than any other, has determined the political thought and institutions of Europe. 


\section{CHAPTER V}

SOME EDUCATIONAL ADVANTAGES OF THE CLASSICS

DIE Griechen sind, wie das Genie, einfach; deshalb sind sie die unsterblichen Lehrer.

Nietzsche.

But is not our own literature an adequate substitute for the classics if not an improvement on them? And is there not something to be said for feeding children on their mother's milk, instead of surrendering them to foreign nurses? These are obvious and fair questions to ask, and I propose in this chapter to consider the respective educational merits of ancient and modern literature and to put successively the following questions:

(a) How does our own literature compare with Greek? (This has been to some extent dealt with in Chapter III.)

(b) Is it really better for a nation to be nourished mainly on its own past? 


\section{ADVANTAGES OF THE CLASSICS I 55}

(c) What are the general educational advantages claimed for the classics?

(d) In what sense can the classics be considered an introduction to modern problems?

It is only possible here to glance at these questions and to indicate certain lines of discussion, and it is always to be remembered that from their nature an absolutely definite solution is impossible. Educational problems are not like income-tax papers, where the replies can be precise; we can only give rough estimates and general forecasts.

How does our literature compare with Greek?

It is ungrateful and rather impious to match against each other the illustrious names of two illustrious literatures. As in religion, so in literature, differences of age or nation do not break the unity or disturb the peace of those who have joined the company of the departed great. But for educational purposes it is instructive to make these comparisons, and therefore, premising that anyone who does not know both Greek and English is the poorer for his ignorance, let us set the armies in array. (Latin for the most part I leave out of account, and no critic can object if I put myself at a disadvantage by meeting him 


\section{56 CLASSICAL EDUCATION}

on one leg instead of on two.) First comes Homer, whom we might match if we could combine the simplicity and humanity of Chaucer with the grandeur and art of Milton; as it is we may accept the Poet Laureate's judgment, that he holds an 'undisputed throne.' ${ }^{1}$ Passing to the dramatists, we have in Shakespeare a genius beyond comparison, though for educational purposes it would be difficult in English to find anything to match the combination of the three Greeks; we have nothing in tragedy so titanic as Aeschylus, so exquisite in art and plot construction as Sophocles, so curiously modern and human as Euripides (the three combined would be the highest literature man can conceive), nor have we anything so instructive as the development of art and thought which these three afford as they succeed each other in an age of intellectual progress and rapid change. In comedy Aristophanes is unique in the literature of the world, but a

${ }^{1}$ He writes of Shakespeare:

Whom, when she (England) bore, the Muses lov'd

Above the best of eldest honour

-Yea, save one, without peer-

And by great Homer set,

Not to impugn his undisputed throne,

The myriad-hearted by the mighty-hearted one. 


\section{ADVANTAGES OF THE CLASSICS I 57}

Menander can be had, and not in fragments, if we go to France for Molière.

In poetry, especially if the greater abundance and scope of our own literature be considered, English offers at least as much to the student as Greek. In some departments of prose this is not so. Oratory is its least important branch; but here Lord Brougham speaks of Demosthenes' Speech on the Crown as "The Greatest Oration of the Greatest of Orators," and for sustained perfection our own speakers, with their rather ragged, shapeless speeches and brilliant purple passages, cannot compare with the great Greeks; they did not take the same trouble in writing, and consequently we do not take the same pleasure in reading. An exception should be made of Burke ; no Greek politician has his rich language or profound political wisdom. In history our inferiority is greater. Our historians have lacked either impartiality, or else the style, or, still more important, the imagination, adequate to the momentous issues, tragic events, and commanding personalities of history. We have no one to compare, in their very different gifts, with Herodotus or Thucydides. And neither in our own, nor in any other literature will the historian find a model to match 
with the latter. Macaulay, Froude, and Green are brilliant partisans. Clarendon or Gibbon comes nearest our ideal, but Gardiner speaks of "Clarendon's usual habit of blundering," and Gibbon, though both scientific, eloquent and an artist, is a model neither of style nor of impartiality. His subject is the fate of a bizarre and decadent absolutism, and his work is less like a picture than a great piece of ancient tapestry, where we admire the harmony of colour, the skill of design, the ample and stately pageant which passes under our eyes, but never quite feel as if the figures were human or alive. Byzantium is too remote from our life to excite our sympathy, pity or fear, and we miss the human interest, which Thucydides' story of the rise and fall of a great democracy awakes. I have already quoted the characteristically generous tribute of Macaulay to him.

But it is in philosophy that we compare least favourably with the Greeks. Hellenism has influenced the world deeply in every branch of intellectual life, but her greatest influence probably has been through her philosophers. Socrates, Plato, Aristotle, Epicurus and the 'budge doctors of the Stoic fur'-all educated 


\section{ADVANTAGES OF THE CLASSICS I 59}

men have heard these names; if they had never lived, the world would have been different beyond conceiving from what it is to-day. They are the culmination of the Greek genius, and perhaps its greatest glory; they are the natural offspring of its bent, children of the marriage between reason and life. They cover the whole field of philosophy; in metaphysics, morals, and politics they started the game, in whose tracks, since their day onwards, the world of intellect has been afoot. Philosophy has often seemed dull and dry, but they united logic and feeling, imagination and analysis, and qualified with radiant vision the dry light of thought. This is true of all of them to some extent, and of Plato in the highest degree. $\mathrm{He}$, and he alone in the world, was at once poet and philosopher, and in both his gifts supreme. Yet they were not mere writers of the study. It is the glory of Greek literature that in its greatest representatives art and life are not divorced; the teaching of Socrates was a mission; the Republic of Plato and the Politics of Aristotle were inspired by the political conditions of their day.

Against these names we can produce many illustrious writers from Hobbes to Mill: but they are weak just where the Greeks are strong. With 
the exception of Bacon, Berkeley, and the Cambridge Platonists, our great philosophers belong to one school ; they are hard-headed, business-like Englishmen, rather dry and unimaginative. Locke commences his essay Concerning the Human Understanding thus: "Since it is the understanding that sets man above the rest of sensible beings, and gives him all the advantage and dominion which he has over them, it is certainly a subject, even from its nobleness, worth our labour to inquire into." This opening, with the afterthought, "even from its nobleness," is characteristic of English philosophy. Its sanity and good sense are admirable and indispensable; its famous child, utilitarianism, is a welcome addition to the European family. But neither man nor philosophy can live by sense and sanity alone; a touch of vision must be added for the science which deals with such high things, and it is hard to say where in English philosophy it is to be found. Bacon, who has plenty, devoted himself to experimental philosophy, and never dealt completely or systematically with politics and morals. Berkeley and the Cambridge Platonists were less many-sided than Plato and Aristotle, and far smaller men. On the other hand, if we turn to pure science, we shall not need 


\section{ADVANTAGES OF THE CLASSICS I6I}

to leave our own circle: Newton and Darwin offer examples as admirable as any in the world. Our deficiencies are on the human side of philosophy. The plain reason why we read Plato and Aristotle is that in their subjects they are as supreme as Shakespeare in his. They are among the very few writers who, however highly we think of them, startle us, when we read them again, as being so much greater than we had thought. If anyone supposes he can replace them, let him try; let us have their substitutes named: but great thinkers are not like motor-cars-numbers of first-class makes, each pretty well as good as the other.

To conclude our comparison of Greek and English achievement in the various branches of literature, we may say that in literature proper Greek has probably more writers of the very first class; though English has a greater quantity of excellent work, and is superior in certain kinds of literature, such as novels, letters, biography and essays, while in the romantic interpretation of nature and human life we have broken ground which the Greeks left comparatively untouched; in eloquence Greek has the greatest masters, and the more finished and perfect models of art, while English again has the advantage in quantity and 
width of range; in history, no English writer unites, like Thucydides, impartiality, imagination and literary art; in pure science we need not go beyond our own shores, but in philosophy those who seek for the combination of logic with imagination, of analytic with constructive power, and wish to see the intellect of man in its purest form, and freshest and most vigorous action, will find it in Greece. The gaps in our own ranks will be strongly reinforced if we go outside Britain, and include thinkers like Pascal, Spinoza, Descartes, Kant, Hegel, and orators like Bossuet and the French school; but it will be difficult anywhere to find a match for Thucydides and Herodotus, Plato and Aristotle.

But is it not better in any case for a nation to be brought up on its own literature! Are not Thames and Avon, rivers of England, better, for us at least, than all the waters of Greece?

If to read the classics was to exclude English, there would of course be no doubt of our choice. But English enters, or ought to enter, into all school curricula; it is read at home and in leisure hours, and it is the more enjoyed and the better appreciated if it is not associated with class-rooms 


\section{ADVANTAGES OF THE CLASSICS I63}

and text-books and examinations. There are no walls round its fields, and the wish to roam them gives admission. With the classics it is not so. The high palisade of languages unlike our own surrounds them, and must be surmounted young, or it will almost certainly never be surmounted at all. Not one in a thousand will learn Latin and Greek except as boys ; if not then, never, and, like Pushkin, they may say in late life, with unavailing regret, "How often do I tear my hair for not having had a classical education." 1

Of course for an Englishman to be ignorant of his own literature or history is as bad as for a child to know nothing of its own family; but we cannot argue from this that he should be exclusively or even mainly brought up in it. Nowhere has this literary nationalism been more loudly preached than in modern Germany, whose education has been largely influenced by it since I 890 , when the Emperor, then young, announced his policy. "Whoever," he said, "has been at a Public School (Gymnasium) .. . knows where the fault lies. The fault lies in the want of a national basis. We must take German as our foundation; we have to educate young Germans, not young Greeks and ${ }^{1}$ Quoted by Zielinski, Our Debt to Antiquity, p. 112. 
Romans." I The immediate sequel was a reduced importance of the classics in secondary education, but recent years have revealed more questionable aspects of the movement. Not only has Germany been obliged to supplement the poverty of her literature by claiming Dante as a German, because, among other reasons, "he has a characteristically Germanic countenance," 2 and Shakespeare, "because Germany is his spiritual home"; but also this concentration on Deutschtum has encouraged the monstrous egoism which, sitting in rapt contemplation of its virtues, finds everywhere its

\section{Own vast shadow glory-crowned And sees itself in all it sees.}

This argument can be pressed too far. There is no absolute protection against self-absorption and blindness to our own weaknesses. Still a knowledge of other civilisations, with which we can compare ourselves, is some help. And when we look for such civilisations, where can we find them except in the classics? Surprising as it may seem, there are no really satisfactory alternatives.

${ }^{1}$ Quoted in Mr. J. W. Headlam's report (p. 21) (Board of Education Special Report, qol. 20, The Teaching of Classics in Secondary Schools in Germany).

${ }^{2}$ Chamberlain, o.c. p. 538 . 


\section{ADVANTAGES OF THE CLASSICS I 65}

Feudal societies are useless for the purpose, and to study them in this connection would be like studying modern warfare by the light of the Crusades, possible, but unprofitable. Nor does the rest of European history offer any instances either so complete or so modern in their ideals and difficulties as Greece and Rome. It may be paradoxical to call the ideals and difficulties of Greece and Rome modern, and some will think that the parallel about the Crusades might be extended to the study of Greek and Latin as a whole. If they will have patience, I hope to have justified myself by the end of this chapter. Meanwhile I pass to my third point, the general educational advantages of the classics. The most obvious of these are their completeness, simplicity and the fact that they resemble us sufficiently to admit of comparison, yet are sufficiently different to admit of contrast.

Consider for a moment their completeness. In their literature we see the evolution of epic, lyric, tragic, poetry: the comedy of broad humour is succeeded by the comedy of manners; the literary epic, the elegy, the pastoral, the epigram follow. Then there is their prose, historical, oratorical, philosophical, and finally, artistic prose for its own 
sake. Then there is their thought, commencing in bold scientific speculation, developing in the fields of morals, politics, psychology, logic, metaphysics, and branching out in hedonism of different types, materialism, idealism, scepticism, stoicism, asceticism, mysticism; then there are the later developments of the Alexandrian epoch, when the various sciences are mapped out, and each tills laboriously its own field. Most of the adventures of the human mind are in Greek literature, one developing into another with a method and logic that is as wonderful as, and indeed explains, their completeness. Or turn from literature and thought to history, and see the examples of various forms of government, absolute, military and limited monarchies, oligarchies, democracies of different types, followed by absorption into the Roman empire with more or less autonomy: note the colonising activity of Greece (two of the three great colonising epochs of the world fall in its history); note the incessant political experiment and speculation, theories of communism, federal governments, arbitration treaties, commercial treaties, problems of naturalisation of aliens, of emigration, of the position of women and slaves. And so far I have not spoken of Rome. Let critics of the classics 


\section{ADVANTAGES OF THE CLASSICS I 67}

produce any other civilisation so complete, so fitted to introduce boys to the activities and adventures of the human mind, so able in every direction to open windows on to life.

Further, Greek literature has a curious inner completeness, which for educational uses gives it a singular advantage. By some chance its great writers wonderfully supplement each other's deficiencies, so that we have in Greek not only famous tragedians, historians, orators and philosophers, but different and representative types of the human mind in each of these branches of art and thought. Greek literature is like a picture gallery, which is small, but has perfect examples of all the great schools of art. In tragedy Aeschylus, austere, tremendous, elemental, his atmosphere charged with mysterious forces, his characters survivals from a heroic age, his plots crude, his imagery audacious, is followed by Sophocles, the perfect artist, a master of plot and language, yet a great poet besides; and he again by Euripides 'the human,' with his interest in the life of the common people, his sympathy with the oppressed and suffering, his hatred of wrong, his acute restless brain, sceptic and dreamer, intellectualist and poet. The circle is complete. Or take oratory, and note 
how Lysias, the genius of plain, natural, spontaneous style, is supplemented by Isocrates, with his elaborate rolling periods, a little wanting in spontaneity or fire, and he again by passion incarnate in Demosthenes. Or take history, where Thucydides, intent on tracing step by step the progress of his country's tragedy, has almost banished personalities from his pages, and tells us nothing of the common life of Athens, while Herodotus is interested in every human being he meets, and records the gossip of the market, and the quaint customs of the foreign countries he visited. With philosophy it is the same, as we are reminded by the saying that every man is born a Platonist or an Aristotelian.

This richness, this completeness of the civilisations of Greece and Rome is one of their recommendations; another is their simplicity. They exhibit an epitome of man in himself and in his relations with other men; the web of human character and society is there, as it is in modern literature; but it has a far simpler form, so that we can trace the several strands out of which it is woven, and examine them more easily. The difficulty with modern history and modern thought 


\section{ADVANTAGES OF THE CLASSICS I69}

is their complexity; we grope through them, and find it difficult to know where we are, what are the forces and problems around us. It is like being in a modern factory; the machinery spins, the pulleys, cogs, and driving wheels are in motion, but we cannot detect their connection and interdependence, the origin of all this activity or its purpose. To understand it we must study machinery on simpler models and a smaller scale. That is precisely what the classics are in education. "The ideas and laws which seem to play in inextricable confusion in modern life, are presented by Plato and Aristotle in a form which is as free from confusion as matters of such complexity can be. Nearly all the problems which bewilder us by their mutual entanglements in modern thought and writing, we find attacked straightforwardly by the ancient Greeks." I They are the small simplified models on which we master the ground principles, before we examine the big machine. They save us from the bewilderment of being thrown at once into the complex of modern history and thought.

This simplicity was partly a happy accident. Athens and Rome stand on the upper courses of

${ }^{1}$ A. W. Pickard Cambridge, Education, Science and the Humanities, p. 23. 
the rivers of civilisation, while we are on the lower reaches, where confluents from many sources have swollen and disturbed its waters. Our civilisation is compounded of contributions from Greece, Rome, Palestine; and added to these are by-products of its own, Feudalism, the Papacy, the Renaissance, the Reformation, our own and the French Revolution, the Industrial Revolution. Could the compound of all these forces be otherwise than confused and confusing? But Greece was made by herself, and Rome by herself and Greece, and they and their creations are simple. Monarchy, oligarchy, democracy were evolved by the nation that gave them their names, and their forms in Greek history, and their conception in Greek thought are clearer and less complicated than they have ever been since. In the classics we study their development, and the development of the state, in domestic, imperial and foreign relations, on an easily comprehended model which has the essentials in simple form.

But partly this simplicity is due to a peculiar quality of the Greeks. They had a genius for the anatomy of thought; they knew exactly where the joints of a subject lay, and could resolve a whole into its parts and place it ready for inspection; they 


\section{ADVANTAGES OF THE CLASSICS I7I}

were born dissectors. That is why in all fields of thought they so often discovered the problems to be solved (to ask the right questions is the gift and infallible sign of genius, and the great advances both in the history of thought and in the special sciences, have been made by the men who could do this). We see this instinct in Herodotus' naive, yet acute, discussion of the merits of monarchy, oligarchy and democracy, ${ }^{1}$ but it reaches its perfection in Aristotle, the greatest of analysts. His treatises are incomparable introductions to their subject, not only for their wisdom, but still more because they exhibit so lucidly the questions in doubt, the points to be proved. Many modern books can be read from cover to cover without our ever being quite clear as to the exact problems at issue. The writer gives us an account rendered of judgments or conclusions, which shews neither the individual items nor how the sum total is reached, and leaves us doubtful if the result is correct. Compare Aristotle's introduction to his discussion of ethics with the opening of a modern book on the subject, and note how lucidly and carefully he puts before us the root problem of ethics, beginning with deliberation to $\operatorname{limb}$ the tree ${ }^{1} 3$. 80. 
at its foot instead of taking a flying leap into its branches. "Every art and every scientific inquiry, and similarly every action and purpose, may be said to aim at some good. . . . As every knowledge and moral purpose aspires to some good, what is in our view the good at which the political science aims, and what is the highest of all practical good? As to its name, there is, I may say, a general agreement. The masses and the cultured classes agree in calling it happiness, and conceive that to live well ( $\epsilon \hat{\dot{v}} \bar{\eta} \hat{\eta} \nu$ ) or to do well ( $\epsilon \hat{\dot{v}} \pi \rho a \dot{\tau} \tau \tau \epsilon u$ ) is the same thing as to be happy (evidauroveiv). But as to the nature of happiness they do not agree, nor do the masses give the same account of it as the philosophers. . . . It would perhaps be a waste of time to examine all these opinions, it will be enough to examine such as are most popular or as seem to be more or less reasonable." ${ }^{1}$ Now hear the beginnings of Dr. A. E. Taylor's Problem of Conduct: "With this prefatory word of explanation I turn at once to the subject which is to be considered in the following pages-the relation between ethics and metaphysics. It seems clear that in all cases in which we can say that two sciences stand in close connec${ }^{1}$ Nic. Ethics, ro94a, I f.-1095a, I 4 ff. (tr. Weldon). 


\section{ADVANTAGES OF THE CLASSICS I 73}

tion with one another, the nature of the relation between them must be conceived in one of two ways. Either one of the two sciences is actually derivative from the other, and dependent upon it for its principles and methods, or else they are independent and coordinate branches of inquiry, and the relation between them is simply one of mutual contact and support at various points. The difference between the two cases is too obvious to need a lengthy explanation, but we may in passing illustrate it by comparing the relation of mechanics to geometry, or of acoustics to kinematics, with the very different relations which, in the view of the most competent authorities in either science, obtain between psychology and physiology." 1 How much easier it is with Aristotle to tell where we are and what we are about! And Mr. Taylor's book was not chosen for special obscurity. If anyone cares to glance at the opening of the ethical writings of Hume, Green, Martineau, Spencer or Rashdall, he will find that they contrast quite as unfavourably with Aristotle: only Henry Sidgwick has something of the Greek's precision. I do not of course mean our study of politics and ethics is complete if we have read Aristotle; 
but I say that the simplicity and lucidity with which he poses their problems make him a better introduction to this subject than modern writers.

Nor is this simplicity and lucidity only shewn in the Greeks' power of expounding a problem. It is the essential mark of Greek literature. Writers speak of its light, clarity, sincerity, directness, concreteness, eternal outline-the phrases are all aimed at this power of going straight to the point, and displaying it with the accidental trappings removed. Modern writers are apt to be like modern statues, folds of heavy drapery muffle their form: Greek thought is naked, or if draped, the drapery only reveals the outlines beneath. No writers have less of the accidental, more of the essential in their descriptions; they bring us into the immediate presence of what they describe. It is difficult to express this quality, but anyone who knows Greek literature will know it. We see it in Simonides' epigram on the dead at Thermopylae

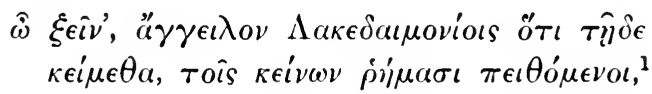

1 " Stranger, tell the Lacedaemonians that we lie here, obeying their commands." 


\section{ADVANTAGES OF THE CLASSICS I75}

in Sappho's description of stars paling before the moon

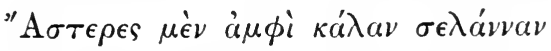

$$
\begin{aligned}
& \text { aî' 'a }
\end{aligned}
$$

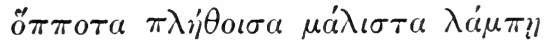

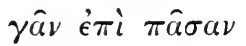

$$
\begin{aligned}
& \text { a } \rho \gamma v \rho i{ }^{1}{ }^{1}
\end{aligned}
$$

in Thucydides' account of the disastrous retreat of the Athenian army from Syracuse in the torrid September of $4 \mathrm{I} 3$ B.c.: "The Athenians hurried on to the river Assinarus. They hoped to gain a little relief if they forded the river, for the mass of horsemen and other troops overwhelmed and crushed them; and they were worn out by fatigue and thirst. But no sooner did they reach the water than they lost all order and rushed in ; every man was trying to cross first, and, the enemy pressing upon them at the same time, the passage of the river became hopeless. Being compelled to keep close together, they fell one upon another, and trampled each other under foot: some at once perished, pierced by their own spears; others got entangled in the baggage and were carried down the stream. The Syracusans stood upon the further bank of the river, which was steep, and

1 " The stars around the fair moon hide at once their bright face, when, about her full, she throws her silver light over all the earth." 
hurled missiles from above on the Athenians, who were huddled together in the deep bed of the stream, and for the most part were drinking greedily. The Peloponnesians came down the bank and slaughtered them, falling chiefly upon those who were in the river. Whereupon the water at once became foul, but was drunk all the same, although muddy and dyed with blood, and the crowd fought for it. At last when the dead bodies were lying in heaps upon one another in the water and the army was utterly undone, some perishing in the river, and any who escaped being cut off by the cavalry, Nicias surrendered to Gylippus, in whom he had more confidence than in the Syracusans. He entreated him and the Lacedaemonians to do what they pleased with himself, but not to go on killing the men." 1 Thucydides indeed is one long instance of this directness, especially in his seventh book, the greatest piece of historical writing in the world: Plato's famous analysis of tyranny, oligarchy and democracy, is another illustration: ${ }^{2}$ but all Greek literature is a continuous example of it.

The same quality is betrayed in their language. Philosophy ('love of wisdom'), history ('en-

$$
{ }^{1} 7.84 \text { f. (tr. Jowett). } \quad 2 \text { Republic, } 544 \mathrm{ff} \text {. }
$$




\section{ADVANTAGES OF THE CLASSICS I 77}

quiry'), geography ('earth picture'), anatomy ('cutting up')- there is a vividness about these words which are not mere symbols, but living reflections of the ideas they represent. It is the language of pioneers, touched with the freshness of first discovery. So with their philosophical language: contrast in the following characteristic instances the abstractness of English, the concreteness of Greek: Reality- $\tau \dot{o}$ oै (what is); ideal

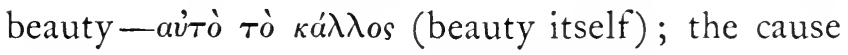
— $\boldsymbol{\tau}$ ò $\delta \iota^{\prime} \tau \iota$ (the on account of which); essential

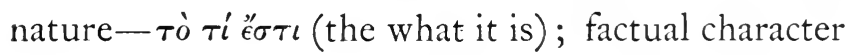

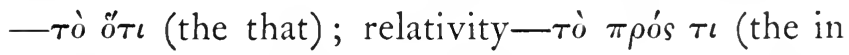
relation to something); the final cause- $\tau \dot{o}$ ov ${ }^{\prime \prime} \nu \in \kappa a$ (the for the sake of which). Now open, I will not say Kant with his 'transcendental apperception,' 'synopsis of the manifold a priori,' 'teleological physico-theology,' 'intuitable synthesis,' etc., but a modern writer like Dr. Rashdall, who aims at lucidity and simplicity of expression, and note the stock vocabulary of modern philosophy; 'the hedonistic psychology involves a hysteron proteron,' 'dualism of the Practical Reason,' 'Subjective Idealism,' 'Objective Validity,' 'conation,' 'sensationalist,' ' the Absolute.' The Greeks walk on the real earth, or something like it; in modern 
phraseology we seem to be among unsubstantial cloud-shapes. Let us admit by all means, that this queer jargon is necessary, and has grown up to meet a real need. Still it is an advantage to introduce the student in his early days to the stock ideas of philosophy in a simpler and more concrete form ; he will grasp them better if he meets them naked, divested of voluminous folds of language. We shall force him to think what 'reality' and 'relativity' mean when we present them to him as 'what is,' and 'a being in relation to something' $;{ }^{1}$ he will be less able to pick up and retail the phrases like a parrot, for the Greek words have a concrete quality which brings before the mind the idea they represent. Brought up in such a school he will be less likely to use language without thinking of its meaning, and in consequence may avoid the most fatal of blunders-the mistaking of words for things.

Whatever they are writing about, be it scenery, a historical event, an abstract problem, some one's character, it is just the same. The Greeks put

${ }^{1}$ The English translations I have given sound clumsy and give no idea of the lucidity of the Greek. It is true that Locke and Hume are simpler than more modern writers; but even they have nothing so simple as the Greek phrases quoted above. 


\section{ADVANTAGES OF THE CLASSICS I 79}

their subject before us naked, as the spirits in Plato's myth that came before Minos and Rhadamanthus in Hades, to be seen and judged. One can hardly exaggerate the value in education of this quality, which is the property and, in large manner, the charm of Greek literature. It is a perpetual challenge and lesson, voir clair dans ce qui est, to rise out of the mists of abstract language and vague words and journalistic jargon into a region where phrases are less able to masquerade as facts, because the air is clear. People talk of finding something to replace Greek in education. Perhaps they will discover substitutes for the Greek poets; perhaps, though no one has yet told us where they are to come from, they will find another Socrates and another Aristotle. But one thing certainly they will not be able to match--the lucid, transparent atmosphere in which the creations of Greece, in prose or poetry, all move.

But, it is objected, after all, the ancients are not ourselves, and in our devotion to them we lose touch with modern thought and modern problems. "Our governing class," urges a critic in the Times, "thanks to the facilities for a classical education existing in this country, know far more about the 
ideas of the Gracchi than they do about the notions that such people as, for example, $\mathrm{Mr}$. Cole and $\mathrm{Mr}$. Mellor and the editor of the New Age, are spreading industriously in the country." 1

I do not know how far the writer of the letter from which I quote is acquainted with Oxford, but in my experience intelligent undergraduates are not in that state of innocence which he supposes; indeed many of them are in more danger of thinking too much of the New Age than too little. And even if they were not, it is doubtful whether an education in which the 'notions' of Mr. Cole and Mr. Mellor took a prominent place, would really be so satisfactory after all. Of course no one supposes that a study of thought and history is complete when we have mastered the classics. But the simplicity and lucidity with which they raise one after another the fundamental problems of life and thought, make them a better introduction to these than modern writers. They give, as a German writer has said, not mass of knowledge, but clearness of fundamental principles (Klarheit der Grundanschauungen). We require both: but the first is useless without the second. It does not need much knowledge of education to realise that

${ }^{1}$ Letter by D. P., Times, July 24, I 916. 


\section{ADVANTAGES OF THE CLASSICS I8I}

the whole power of the mind to judge rests on Klarheit der Grundanschauungen, the grasping quite clearly the simple elements, of which the infinitely complex forms of modern society and thought are composed. Want of such clearness is the greatest source of error, and produces the type of man common and dangerous in the age of journalism, who is at the mercy of the last bee that happens to have lodged in his bonnet.

Because the first task and greatest need of education is to secure this clearness, it is continually forced back into the past. It is compelled, for instance, in its first stages to take Mill or Rousseau or Hobbes or Aristotle as its text-book of political science rather than $\mathrm{Mr}$. Wallas or Mr. Sidney Webb, or the 'notions' of $\mathrm{Mr}$. Cole and $\mathrm{Mr}$. Mellor. The moderns are more complicated ; they presuppose, for their full understanding, knowledge of their predecessors, and they contain, mixed with much truth, errors on which time has not yet passed judgment, and which are therefore difficult to detect. This makes them unsuitable food for the young student, and education turns to the older writers, who have the principles of the subject in a simpler form, whose views have been scrutinised, and whose errors laid bare. By so doing she loses 
touch for a moment with the most modern developments; but she does so deliberately, knowing that the student will grasp them more quickly and judge them more accurately, if he has made his ground principles sure. The study of the classics follows from a logical application of this theory. We might, it is true, go back to Mill or Rousseau (in the Oxford Greats school this is to some extent done) ; but we should still be open to the objection that we were losing touch with contemporary problems, and we should be slaking our thirst at less pure and inferior streams. Instead, we go back to the great fountain heads. Greek has the ground principles presented in their first and simplest form by writers of genius whose mistakes are not likely to mislead us, because after the criticism of 2000 years they are well known.

And meanwhile, in studying the classics we are acquiring standards independent of our own age and its prejudices, by which to judge ourselves and it. Without some such standards we are like boys who have been brought up entirely at home, and have never been disciplined by coming to know dispositions and ideas and habits foreign to a narrow circle. Hazlitt has well described the dangers of such an education. Writing in circum- 


\section{ADVANTAGES OF 'THE CLASSICS I 83}

stances not unlike our own, and defending the classics against attacks made on them after the Napoleonic Wars by critics who wished to give science a predominant place in education and to substitute the education of things for the education of words (as they called it), he says: "It is hard to find in minds otherwise formed" (than by a classical education) "either a real love of excellence, or a belief that any excellence exists superior to their own. Everything is brought down to the vulgar level of their own ideas and pursuits. Persons without education certainly do not want either acuteness or strength of mind in what concerns themselves, or in things immediately within their observation. But they have no power of abstraction, no general standard of taste or scale of opinion. They see their objects always near, and never in the horizon. Hence arises that egotism which has been remarked as the characteristic of self-taught men, and which degenerates into obstinate prejudice or petulant fickleness of opinion, according to the natural sluggishness or activity of their minds. For they either become blindly bigoted to the first opinions they have struck out for themselves, and inaccessible to conviction ; or else (the dupes of their own vanity and shrewdness) 
are everlasting converts to every crude suggestion that presents itself, and the last opinion is always the true one. Each successive discovery flashes upon them with equal light and evidence, and every new fact overturns their whole system. It is among this class of persons, whose ideas never extend beyond the feeling of the moment, that we find partisans who are very honest men, with a total want of principle, and who unite the most hardened effrontery and intolerance of opinion to endless inconsistency and self-contradiction." I We may not agree with every word of this criticism, but we all know instances of the type which Hazlitt is attacking; and there is no better medicine against its dangers, than to be able to withdraw from the modern world, and view and judge it in the light of other civilisations than our own.

If so, we are driven to Greece and Rome. Not only are they " two cities set on a hill, which could not be hid; all eyes have seen them, and their light shines like a mighty sea-mark into the abyss of time." But nowhere else in European history shall we find two civilisations which satisfy the necessary conditions. They, unlike the states which grew up on their ruins, have run their full ${ }^{1}$ The Round Table, No. 2. 


\section{ADVANTAGES OF THE CLASSICS I 85}

course from start to finish ; they have been judged and heard the final verdict of time; because they are dead their history excites little prejudice and passion, and they resemble us sufficiently to admit of comparison, yet are sufficiently different to allow a contrast. There is no other Western civilisation of which this can be said.

The very difficulty of penetrating to their thought and life is an advantage ; it is a training in insight and sympathy, and develops the faculty of getting inside other people's minds, which all men need, whether they are politicians or teachers, civil servants or merchants. The very differences of the classical civilisations from our own are instructive. Is it not salutary in the days of big federations and world empires to test and check our beliefs by comparison with peoples who built up their life within the walls of small cities and thought that there should be "a limit to the state" ?1 The comparison will not change our views, but it may save us from some of the excesses of megalomania. The achievement of Athens will remind us that bigness is not greatness, and her practice will teach us not in the state to forget the

${ }^{1}$ Aristotle, Politics, 7. +. 9. Here, and generally, I have used Jowett's translation. 
individual. "It is clear," says Aristotle, "that that form of government is best, in which every man, whoever he is, can act for the best, and live happily" ${ }^{1}$ and he was uttering the principle which controlled Greek politics.

And yet the history of Greece and Rome is always reminding us of our own difficulties. This brings me to my fourth point-the sense in which the classics introduce us to modern problems. It is almost impossible to persuade those who do not know it, that classical literature is in any sense modern; they think of it as something primitive and barbarous, and they will not believe that Euripides or Seneca have at least as much in common with the twentieth century as Scott or Thackeray. So I will give a few instances to indicate how the classics teem with modern characters, situations, problems. Again, for brevity's sake I will take these instances from Greek only.

Greek history is at once more and less akin to the modern world than at first seems. We might suppose that Athens, the earliest and most complete democracy in Europe, would have many lessons to teach us; on the other hand, we might ${ }^{1}$ Aristotle, Politics, 7. 2. 5. 


\section{ADVANTAGES OF THE CLASSICS 187}

think that a slave-owning society, whose women were unemancipated, was too remote from conditions of to-day to be instructive. Both these suppositions are dangerous. The Athenian woman was not such a puppet as we suppose ; and if most Athenian men, like the modern French, thought that the complicated sex problem was logically solved by assigning the home and the family as the province of woman, there are plenty of signs in fifth and fourth century literature of views which we associate with the suffragettc. Nor did the slave system make so much difference as we fancy. The member of our upper or middle classes, living partly or wholly on his dividends, which represent an inherited or acquired right to other men's labour, has affinities with a slave-owning Athenian ; while the difference between our industrial classes and the Greek slave is spiritual rather than material. ${ }^{1} \quad$ No doubt it is a very important difference, but it is not such as to make comparisons between ancient and modern society unprofitable. On the other hand, arguments drawn from Athens as to the fate of democracies are notoriously misleading: Athens was a small city, not a big modern

${ }^{1}$ See A. E. Zimmern, Was Greek Cirilisation based on Slare Labour? 
state, and her democracy was far more complete than ours is ever likely to be. So we need here to be even more cautious than usual in our historical inferences.

Yet it is true that Greek history is instructive, and at times surprisingly modern. There is the unique spectacle of Sparta--that country of austere and Puritan heroes, who thought a state could exist without a civilisation, and, banishing equally art and commerce, literature and gold and silver, have left the world doubtful whether to admire the virtues, or to despise the narrow efficiency, of these human ants; Sparta teaches the fate of a nation which dispenses with thought and art, and affords an excellent contrast with Rome. Then there is Athens, presenting the history of the only democracy before our own which has tried to govern an empire. Glance at her closing phase, of which Demosthenes is the hero. His whole career was a struggle against Philip of Macedon's attempt to subjugate Greece, and his task was to excite a good-natured, peaceable democracy to spend on war money which they preferred to use for social purposes at home, and to sacrifice their own lives on the field of battle instead of paying mercenaries to go in their place. His speeches 


\section{ADVANTAGES OF THE CLASSICS I 89}

are mostly in favour of this policy; his greatest was in defence of it when it had failed. He was successful in so far that he persuaded Athens to spend money and men in fighting Philip; he failed because the democracy awoke too late from its dreams of peace, and found that policies cannot be improvised at a moment's notice, and that tardy efforts at self-defence were useless against an enemy who knew exactly what he wanted to do, and had made every preparation to effect it. At present, we, who are at war with an adventurer nation, can read Demosthenes with greater understanding, as he denounces the designs of an adventurer king: and as he warns the Athenians of their unpreparedness, and implores them to awake to the situation, can recognise that his words might be applied to other times besides the fourth century, and other democracies besides Athens. Indeed the parallel with our situation in I9I4, though not complete, is in many ways very close. Philip's policy was to deal with the nations on his borders in detail, and to amuse Athens with diplomatic negotiations till he had made himself invincible; and there was a strong party in Athens which thought that Athens should leave him alone and conciliate him by a peaceful attitude, unless he actually attacked her territory. 


\section{90

Demosthenes urges that if she waits till then, it will be too late; and his speeches are full of phrases that many people were using in I9I4. "The weakness of your politicians, Athenians, is that they all say what will please you, not what is best for you." "What has given Philip his advantage in the past is that he is first in the field. $\mathrm{He}$ has his power mobilised to his hand, he knows beforehand what he intends to do, and pounces on whom he will: while we are not disturbed and make no preparations till there is something happening. The result is that he gets possession of what he attacks at his leisure, while we come too late, and the outlay we make is an outlay to no purpose."

The lessons in Greek history are nearly all how not to act. Rome teaches us more about politics than Greece, if by politics we mean the art of stable and efficient government. The Greeks were as unsuccessful in practice as they were fertile in theory; successive states rapidly acquired and lost supremacy, none of their brief hegemonies outlasted two generations, and the brilliance of their life and the genius of their historians makes us forget the smallness of the stage on which they played their part. 'The history of Rome is the 


\section{ADVANTAGES OF THE CLASSICS I9I}

history of the making and fall of an empire ; but Greek political life is that of a glorified municipality. The real triumphs of Greece were won in the world of art and thought, and as she is the spirit of reason incarnate, so she teaches us to imitate herself and think about everything under the sun.

I do not quite know where we should go in English if we wished for such lessons, but we cannot escape them in Greek. First there are the Ionian Physicists who turned thought on to the Universe, and asked what it was and how it came there. Then there were the sophists who turned thought on to more human subjects, analysing language and its social use; asking what are style and the art of writing, what the best way to plead a cause and make it plausible ; inventing memory systems; discussing the anomalies of gender, and trying to put grammar on a sound basis; offering to teach 'virtue' and 'politics' and 'wisdom' to anyone who would pay : the acutest and most hardy race of critics the world has ever known. They have come down to us in small fragments, but to read these is to feel ourselves afloat on the sea of free thought, with anchor up and only our own reason to steer us straight. "Man is the measure 
of all things:" "about the gods I cannot know that they do or do not exist ; for many things hinder from knowing, the obscurity of the subject, and the shortness of human life" (Protagoras). "Gorgias lays down in his book ... about Nature three main points in order ; first that Nothing is, second that, even if anything is, it is incomprehensible by man, third that, even if comprehensible, it cannot be communicated or interpreted to one's neighbour." Sentences like these bring us into the thick of philosophy, and though we might use different words, we understand what Thomas Arnold meant by saying: "Not the wildest extravagance of atheistic wickedness in modern times can go further than the sophists of Greece went before them. Whatever audacity can dare and subtlety contrive, to make the words 'good' and ' evil' change their meaning, has already been tried in the days of Plato, and by his eloquence, and wisdom, and faith unshaken, put to shame." 1

Some people may feel that the passages just quoted are in themselves an argument against reading Greek, and that so far from introducing boys to such speculations, we should bury them in the obscurity of the past from which they come. ${ }^{1}$ See Ruskin, Praeterita, c. xi. fin. 


\section{ADVANTAGES OF THE CLASSICS I 93}

To this I would reply in the words which Newman uses when he is arguing against an attempt to expurgate literature of all except its 'Catholic' elements. "If then a university is a direct preparation for this world, let it be what it professes. It is not a convent, it is not a seminary; it is a place to fit men of the world for the world. We cannot possibly keep them from plunging into the world, with all its ways and principles and maxims, when their time comes; but we can prepare them against what is inevitable; and it is not the way to learn to swim in troubled waters, never to have gone into them. Proscribe . . secular literature as such ... you will have refused to a boy the masters of human thought, who would in some sense have educated him, because of their incidental corruption." 1

Such ' masters' we meet when we pass from the sophists to Plato and Aristotle, who, instead of raising cries of horror, or appealing to outraged orthodoxy, or even losing their tempers, quietly took these critical, agnostic spirits as they found them, and cured the diseases of reason by a homoeopathic dose. The sophists had taken the current ideas of their day (just as Mr. Shaw takes ours),

${ }^{1}$ The Scope and Nature of University Educatiom, c. 8. 
and shewn the inconsistencies and inadequacies of them: current ideas, then as now, were of course inconsistent and inadequate. Having tossed them up and down, they threw them, damaged, aside. The public was indignant, but the harm was done, and Athens found herself in the middle of a big political crisis, with her moral currency discredited and her old ideas of right and wrong confounded. So, like a teased animal, she bit the first person who caught her attention, and that was Socrates. Yet Socrates was doing the only wise thing, meeting the sophists on their own ground, treating their theories as they had treated popular morality, and shewing that they were only a shade less superficial than what they condemned. The sophists by applying reason to the moral principles on which human society rests, had nearly brought the house about their ears. Socrates met them by more reason and carried the foundations of the house deeper. So well did he lay them that his work was never undone. Never again after the fifth century do we find in Greece that spiritual disease, which spread so widely then, and which Plato has shewn us in many of his dialogues-on the one side a cynical contempt of established ideas, believing that nothing can really be known, that the beliefs 


\section{ADVANTAGES OF THE CLASSICS I95}

of a society are merely the conventional ideas in which it has been brought up, and that reason is a useful weapon to make a bad case seem good: on the other, an outraged morality, conscious of its intellectual weakness and unable to defend itself. Socrates and his successors had taught virtue to 'give an account' of itself, and the young Greek was no longer, unless he wished it, at the mercy of a sceptical critic with a clever tongue. How it was done, we can read in Plato and in Aristotle's Ethics.

Then, if we pass to politics, what description of the democratic ideal can rival the Funeral Speech of Pericles, of which we have quoted some phrases on p. 74. To-day criticisms are more common than eulogies of democracy, yet it would be difficult to lay the finger on its dangers, more accurately than did another Athenian. His words, cast in the form of a conversation, are worth comparing with those of Thucydides. "Again, consider that, in this state, ... you need not submit to government if you dislike it, or go to war when your fellow-citizens are at war, or keep peace when they are doing so, if you do not want peace $;^{1}$ and again, consider that, though a law forbids your ${ }^{1}$ I need not point out the mudern analogy here. 


\section{96

holding office or sitting on a jury, you may nevertheless do both the one and the other, should it occur to you to do so: and now tell me, is not such a course of life divinely pleasant for the moment?

Yes, perhaps it is, he replied, for the moment.

Once more. Is not the meekness of some of those who have been tried in a court of law exquisite? or have you failed to notice in such a commonwealth how men, who have been condemned to death or exile, stay all the same, and walk about the streets, and parade like heroes, as if no one saw or cared? ${ }^{1}$

I have seen many instances of it, he replied.

And is there not something splendid in the forbearance of such a commonwealth and in its entire superiority to petty considerations? It positively scorns the doctrine which, when we were founding our state, we laid down with an air of importance, to the effect that no one, who is not endowed with an extraordinary nature, can ever become a good man, unless from his earliest childhood, he plays

1 Plato would have seen a parallel to this in the strike, in defiance of the Munitions Act arbitration clause, of the South Wales miners in June, 1915; and he might have considered that the story of the Ulster, and the Sinn Fein, volunteers presented certain similarities to it. 


\section{ADVANTAGES OF THE CLASSICS I 97}

among beautiful objects and studies all beautiful things. How magnificently it tramples all this under foot, without troubling itself in the least about the previous pursuits of those who enter politics; it raises them to honour, if they only assert that they wish well to the commons.

Yes, he said, it behaves very grandiy.

These then will be some of the features of democracy,... and it will be in all likelihood an agreeable, lawless, parti-coloured commonwealth, dealing with all alike on a footing of equality, whether they be really equal or not." 1 Our own democracy has come well out of this war, yet there have been incidents, which enable us to understand Plato's picture of the dangers of that admirable ideal, the liberty of the subject, when it goes to extremes. Another darker and even acuter saying of Plato, that democracy is "weak and unable to do any great good or evil when compared with other forms of government," 2 becomes intelligible in the light of the events of the last few years.

It would be difficult to find a better introduction to politics than Plato's book On the State-The Republic, as we, not very happily, call it. In its first chapter we meet a criticism of the old heresy

$$
{ }^{1} \text { Republic, } 557 \mathrm{f} . \quad \quad 2 \text { Politicus, } 3 \circ 3 .
$$


that right is might, whose close acquaintance we have made since I9I4 in the form: "the state can do no wrong." There follows a discussion which covers almost the whole of life, and produces by the way some surprising paradoxes, such as that women are to fight in the army, that education is only finally to cease with death, that property, and even wives and children, are to be common, and that philosophers are to govern the state.

It does not seem, perhaps, a very promising introduction to politics, this fantastic republic of a dream ; nor is it, if we take the paradoxes as practical proposals. Plato never meant them to be that ; it was merely his way of calling attention to what, on the benches of a legislative chamber, busied with details of policy and administration, men are apt to forget - the great diseases of human nature, of which the actual problems of politics are merely symptoms. Plato's gift is in diagnosis; no one knows better how to go behind the patient's obvious malaise and disclose the unseen weaknesses from which his ill-health proceeds.

He took the suffering human race,

He read each wound, each weakness clear;

And struck his finger on the place,

And said: Thou ailest here and here. 


\section{ADVANTAGES OF THE CLASSICS I 99}

Take the four paradoxes quoted above. They are Plato's way of calling attention to four fundamental difficulties. The first raises the problem which has fitfully worried humanity through the ages and at this moment demands of us an instant solution-the problem, what is woman's place in the world and the relation of her work to man. The second suggests the absurdity of making education stop at an early age ; in Plato's ideal a man is not to think about the world from I 8 to 23 (when his thought will be of little value, because it has no experience of life to correct and develop it), and then go into a business or profession, where mentally he will stick at the age of 23 , and probably never have time to think systematically again; instead he will divide his life between action and thought, alternately a student and a man of affairs, correcting his reflections by practice, and his practice by reflection.

The third paradox conceals the greatest truth of all ; it reminds us that all political weaknesses are due to a single poison in the state, as certainly as the emaciation, the dyspepsia, the rising temperature in consumption are due to one type of bacillus latent in the body; that they result from the selfishness of citizens who remember their private 
interest and forget the interests of others or of the whole; and that this selfishness is rooted not only in private property, but also in private families-a man who would not be selfish for himself will be selfish for his wife and children. The fourth paradox will be resented by those who believe that nations should be governed by 'business men.' Plato had no belief in either business men or professional politicians as such; the best rulers, he thought, are men, "ready and willing to taste every kind of knowledge, who address themselves joyfully to their studies with an insatiable appetite .. . and who love to see truth." I The world has not been very happy in its few philosopher kings, who have generally lacked force and will; yet as life grows more complex, and the state takes more and more of it under its control, we shall find it easier to understand the greatness of the need which Plato divined.

"But you cannot manage a state on these lines." That is quite true, and Plato knew it, and says so in his Laws. We do not go to him for practical statesmanship; the 'notions' of $\mathrm{Mr}$. Cole and

${ }^{1}$ Republic, 475. Plato's philosopher-king is a very different person from the average philosopher, on whose weakness he is severe. 


\section{ADVANTAGES OF THE CLASSICS 20I}

Mr. Mellor, whatever we may think of them, would help us more there. But the world moves in a see-saw between the dreams of its idealists and the creeping notions of its 'practical' men; and in youth at least it is better to dream the dreams and see the visions. As the day advances, the mists will of themselves blot out the mountain tops, and in the heat and dust of the plain our strength and refreshment will be in our memory of them. That is the sense in which Plato can introduce us to politics. He sees the world as it should be, as perhaps, thousands of years hence, it will be, and his vision takes us a few feet nearer the goal than we should go without it. We may be thankful, in fact, if our rulers are men of the stamp of Agricola, efficient, honest, practical ; yet it is salutary to have in our mind Plato's ideal politicians "who have safely passed through all temptations, and distinguished themselves in all spheres of action and knowledge, and who, concentrating the eye of their soul on that Ideal Good which is the light of the world and making it their pattern, so order their own life and the life of the community and of individual members." 1

Passages like this shew how Greek idealism com${ }^{1} I 6.5+0$. 
pletes, as it is completed by, the practical commonsense of Rome: and it shews, too, another quality of Plato, his sense that political are in the last resort moral and religious problems. Modern political writers discuss arbitration, wages boards, industrial insurance, methods of taxation. Fascinated by the power of machinery in the material world, they make politics a question of suitable mechanism ; impressed by the power of economic pressure, they forget the human soul; and with the growing secularisation of politics there is no corrective to their views. Against this tendency Plato is the most powerful of allies. $\mathrm{He}$ is a socialist indeed, and believes in state control more strongly than any modern socialist. But whereas modern socialisms are based on economic forces, Plato's is built on human character alone. The hope of its success lies in finding politicians of exceptional virtue and intellect and on nothing else; and it is characteristic that education has more space allotted to it in the Republic than any other subject. So always Plato takes us below the surface of political problems and past their machinery, to the tangle of human nature that makes them; and his influence is the more salutary at a time when the world threatens to degenerate into a nest of 


\section{ADVANTAGES OF 'THE CLASSICS 203}

human ants, infinitely busy, with their eyes fixed continuously on the ground.

The method of Plato might be compared to that of the Gospels; he is stimulating, paradoxical; he throws out seeds of thought, at the moment disregarded, whose power and fertility time brings to light. But just because of this he is more irritating and far more difficult to understand than Aristotle, who is the genius of careful analysis and far-seeing commonsense; and those to whom Plato is uncongenial, will turn to his successor and critic. There commonsense dissects not only Plato's communism, but also the socialist theories of Phaleas, who wished, like Robert Owen, to try experiments in a 'new colony,' and of Hippodamas, the father of town-planning, an aesthete who wore his hair long and confined himself to a simple garment in winter and summer. To apply commonsense to the Republic is like applying it to the Sermon on the Mount; still, the Politics states for the first time and in the simplest way the fundamental practical objections to these revolutionary schemes. Witness Aristotle's objection to communistic attempts at levelling. "Unity there should be, both of the family and of the state, but only in some respects. There is a point at which a state 
may attain such a degree of unity that . . . it will become an inferior state, like harmony passing into unison." 1 Such is his criticism of the idea that men will work for the state as for themselves. "That which is common to the largest number of people has least care bestowed on it. Everyone considers chiefly his own interest, and thinks not of the common weal, except so far as he is interested in it. For, besides other reasons, everyone is more inclined to neglect the duty which he expects another to fulfil; as in households many servants are often less helpful than few." 2 Such is the very pertinent remark that "such attempts are chiefly designed to promote the internal welfare of the state, but the legislator should also consider its relation to neighbouring nations "; ${ }^{3}$ a point which has been sometimes forgotten by enthusiastic social reformers. Like all socialist reformers, Plato started by considering what was the ideal state, and having, as he thought, found it, wished to impose it on the world. Aristotle, like all critics of socialism, considered not the abstract desirability of reform, but its suitability to human nature. "Such legislation," he says, " may have a specious appearance of benevolence; men readily listen to
${ }^{1}$ Politics, 2. 5. I 4.
$216.2 .3 \cdot 4$.
${ }^{3}$ Ib. 2. 7.14. 


\section{ADVANTAGES OF THE CLASSICS 205}

it, and are easily induced to believe that in some wonderful manner everybody will become everybody's friend, especially when some one is heard denouncing the evils now existing in states. . . These evils, however, are due to a very different cause-the wickedness of human nature. Indeed we see that there is much more quarrelling among those who have all things in common, though there are not many of them when compared with the vast numbers who have private property." 1 The true remedy for social evils, he says elsewhere, ${ }^{2}$ is not revolution, but careful legislation, and above all education. "The beginning of reform is not so much to equalize property as to train the nobler sort of natures not to desire more, and to prevent the lower from getting more; that is to say, they must be kept down, but not ill-treated." "The state is a plurality which should be united and made into a community by education." 3

These extracts are taken from a single book of the Politics, and give no idea of the subtlety and closeness with which the author argues his points nor of the wealth which the whole work contains. It is full of profound and acute remarks. Who has so well defined the aim of the state; " it
${ }^{1}$ Ib. 2. 5. II.
2Ib. 2. 7. 20.
${ }^{3}$ I6. 2. 5. 15. 
originates in the bare needs of life, and continues to exist for the sake of a good life?" 1 Or the objection to usury, "because it makes a gain out of money itself and not from the natural use of it"? 2 Who has more trenchantly criticised those who devote themselves to piling up money, " intent upon living only, and not upon living well" and even forgetting that the object of having money is to use it ? ${ }^{3}$ If education could implant in us these principles and with them Plato's profound and picturesque reminder that the true object of trade is not to make money but to serve humanity, we should come nearer to solving the social problem than legislation will ever bring us. These are Plato's words. "Dear Cleinias, small, scanty by nature, and the product of an ideal education is the class of men, who set their faces steadily towards moderation, when they feel a want or desire, who are sober when they have a chance of making a big fortune, and who prefer moderate to large gains. The mass of mankind is the exact opposite, unmeasured in their wants and insatiable in their wish to make money, when moderate profits are in their reach. That is why commerce, shop-keeping and hotel-keeping are abused and
${ }^{1}$ Politics, I. 2. 8.
${ }^{2}$ Ib. I. IO. 4.
${ }^{3}$ Ib. 1. 9. 16. 


\section{ADVANTAGES OF THE CLASSICS 207}

regarded as discreditable occupations. But suppose-it is a preposterous and impossible idea of course-.. suppose some one were to compel the best men everywhere to engage for a time in commerce or hotel-keeping or something of the sort ; or suppose . . . the best women were forced to follow similar callings, we should realise how welcome and agreeable these occupations were, and, if they were managed on honest principles we should honour them, as we honour a mother or a nurse." 1 Business men in Greece were, it seems, unsatisfactory, but they are not without their weaknesses in England: and labour unrest will be considerably diminished when coal-owners and miners, and cotton-spinners, and landlords begin to think of themselves not as profit-makers but as the ' nurses' of the nation, to whose care is entrusted its clothing, warming and lodging.

It is not enough to glance through extracts like these, as if they were newspaper articles. Like the Gospel sayings, they should be "read, marked, and inwardly digested," if we are to get the full nourishment they contain; and they are meat in the strength of which we may go many days. Still, even without this, they shew not only how surely

$$
{ }^{1} \text { Law', } 916 .
$$


Greek thinkers lay their hand on the fundamental questions and how simply they pose them, but also how they are misunderstood by critics who suppose that they " may help towards the attainment of literary and oratorical style, or may even add to the amenities of conversational intercourse," 1 but that otherwise they are out of date.

${ }^{1}$ Sir E. Schäfer at the Burlington House Conference. 


\section{CHAPTER VI}

THE CASE FOR GRAMMAR AND PROSE COMPOSITION

STILL, it will be said, granted the importance of studying the civilisations and literature of Greece and Rome, why cannot this be done in English? Why spend so much time on laboriously acquiring two dead languages, when there are excellent translations from them? Above all, why these miserable Latin and Greek proses, with all the grammar and gerund-grinding they entail? The present chapter is an attempt to deal with these two criticisms.

I would note by the way that the first of them ignores certain practical uses of knowing Latin. Latin lies behind French, Italian, Spanish, Portuguese; it is a great help in learning these languages, and essential to a scientific knowledge of them. It has also contributed largely to English. These are stock reasons for its study, and probably more than any other have given it a predominance 
over Greek. I have already glanced at similar arguments on p. 62 f., and they are tco obvious to need further comment. Besides this, Latin is the key both to Roman law and to the documents which hold the history of the Middle Ages, and some persons will need it for these purposes. However, I will not dwell on these arguments, of which the first is clearly the strongest, but proceed to enquire how far those who study Greek and Latin can profitably do so in translations.

Undoubtedly such experiments might be tried, and the newer Universities in particular, which contain students who have never had a chance of acquiring the classical languages and yet wish to know something of the classical literatures, have a great interest in, and a great opportunity of trying them. This is to some extent done already, and it would be very instructive to have an opinion on the results. With certain authors little would be lost, with others something would be gained. North's translation of Plutarch is far more delightful than the late Greek of the Lives; Longinus ${ }^{1}$ is at least as good in English as in Greek; Orrery has exactly caught the manner of Pliny the

${ }^{1}$ I use this name as a convenient way of designating the author of the $\pi \epsilon \rho i$ "̈భovs. 


\section{GRAMMAR \& PROSE COMPOSITION 2II}

Younger; and Philemon Holland's translations are generally more pleasant reading than the originals. Aristotle again can be read with profit in a translation, though the reader will often want to refer to the Greek, and fine shades of thought and expression (important things in philosophy) will be lost ; ${ }^{1}$ translations of works of thought are never quite satisfactory; otherwise the recovery of the Greek text of the New Testament by Erasmus would not have been so momentous an event. The thought of Plato can be found in Jowett's excellent English, though we often lose the simplicity and lucidity of his philosophical language, and, what is more serious, his exquisite style. Thucydides of all the great writers probably suffers least by translation, which disguises his eccentricities but not his genius. ${ }^{2}$

But our difficulties are only beginning here. The authors I have mentioned so far are great thinkers or interesting writers, but, except Plato and Thucydides, they are none of them great men of letters. They are none of them stylists. It is when we come to the poets and prose writers of

${ }^{1}$ Some of the difficulties and objections will occur to the reader who has noted my remarks on page 177 .

2 Many scholars would hotly contest this view. 
genius, that translations are so profoundly unsatisfactory. We might read Johnson or Bishop Butler in a German translation; but what should we say to a critic who suggested that Milton and Shelley, Ruskin and Carlyle were as good in a foreign language as in their native tongue? Plato, for instance - a translation renders his thcught adequately - but gives no idea of the magic and charm of his style. Or try Demosthenes, a quite plain writer. Lord Brougham called him the greatest orator of the world; but no translation which I have ever seen, not even Lord Brougham's, has caught the faintest reflection of his genius. And the difficulties increase when we come to the poets. In English, they are as an Italian scene would be to eyes that have no colour sense and view the world in black and white; or as an oleograph of the Sistine Madonna compared with the original. If a man says that Homer is practically as good in a translation as in the Greek, there is nothing to be done but to listen politely and change the subject. Let anyone who knows Greek look at Morshead's translations of Aeschylus and then turn to the original, and ask himself how much of Aeschylus' genius has percolated into the English of what is really an excellent version. Even 
GRAMMAR \& PROSE COMPOSITION 2 I 3

Professor Murray's translations of Euripides, works of genius, and likely to live as long as our language, never quite succeed in bringing the original under our eyes; when we go back to the Greek, we feel ourselves in a different world.

And this is the real difficulty: it is a different world. Of any poetry most literary critics would say that it cannot really be translated, if to translate is to awake the feelings excited by the original; the thing becomes many times more difficult with Greek and Latin. What might be possible with a modern language, is not therefore possible with them, for, while English and German are allied tongues, English and Greek have no such kinship. The genius of the two languages is totally different, and to translate from one to the other is like the task of the alchemists who hoped to translate an alien metal into gold. It is a pis aller to read the poetry of Goethe or Victor Hugo in English (how many people would think it worth while ?); it is much more to read translations of Homer and Aeschylus.

And we miss something more than a literary pleasure when we read the classics in translations; we miss the genius of the two nations which created them. The best revelation of the Greek genius is the Greek language, fine, subtle, analytic, capable 
of feeling and expressing the most delicate minutiae of thought, never hard, and yet not flabby, the most malleable of tongues and equally capable in the hands of a master like Plato, of wit, dialectic, pathos, satire, poetry or eloquence. And can we really understand the spirit of Rome without knowing the march of the Latin sentence, serried, steady, stately, massive, the heavy beat of its long syllables and predominant consonants reflecting the robust, determined, efficient temper of the nation, as different from Greek as a Roman road from a breaking wave.

The idea that Latin and Greek can be equally well read in translations is a favourite opinion with those who do not know the languages at all, but few, if any, experts will share it. Besides, who would prefer seriously to study a nation and its literature at second hand and not in the original language, especially when that language is so unlike our own? So I will pass to a more serious question. Has the study of these dead languages itself any educational advantages which compensate for the time spent on them? And even if it has, can anything be said for teaching boys Latin and Greek prose? Nothing sticks in the throat of the 


\section{GRAMMAR \& PROSE COMPOSITION 2 I 5}

public more than this practice, and no wonder. It seems indefensible that time should be spent by modern Englishmen in producing elaborate studies in the style of Cicero or Demosthenes (a good prose is no less), in an age when Greek and Latin are not spoken, and in conditions in which real success is, to put it mildly, rare: and it seems, if anything, worse that small boys, far below a sixth form, should be turning small bits of Arnold's History of Rome into Latin, which in many cases is not Latin at all. Can anything be said in favour of such a system?

The problem is twofold, for the study of grammar and the writing of proses are quite distinct. Grammar can be studied without our ever writing prose; and proses in English education are certainly not written primarily in order to learn grammar. The two studies are quite distinct; the objects and value of them are different, and in discussion they should be kept carefully apart.

First consider grammar. The extreme commercialists would no doubt think it foolish to study grammar of any kind, except so far as it is necessary for the use of modern languages; but since all experts, however they may differ otherwise, agree that it is an essential part of secondary educa- 


\section{I 6 CLASSICAL EDUCATION}

tion, we may assume that they are right, and that no boy is educated who has not some idea of the nature and laws of language. After all, language is the most wonderful discovery of man, and more than any other has made his achievements possible; it is more essential to us, and more closely connected with our life than any other science: and grammar study, properly conducted, exhibits it to us as not "a mass of arbitrary rules, but a natural phenomenon governed by law and majestic in its adherence thereto." 1

But why should we study this phenomenon in Greek or Latin rather than in English or French? No doubt it can be done in the modern languages, but they have certain disadvantages. In English at any rate, grammar study is artificial, we know the language already and have no real need to dissect it; while in Latin we must master the grammar in order to understand the language at all, and the study is therefore spontaneous. This objection does not apply to French ; but French grammar is continually referring us back to Latin, and, if it is to be an intelligent study and not a mere learning of rules,

${ }^{1}$ Zielinski, Our Debt to Antiquity, p. 49. He has some excellent remarks on teaching grammar. 


\section{GRAMMAR \& PROSE COMPOSITION 217}

presupposes a knowledge of that language. How, as Professor Zielinski asks, are you to understand without Latin the mysterious genders of French words, or why a word pronounced eh is sometimes written et, sometimes est, sometimes ait, or why heure is written with a final $e$, and honneur without? Obviously such examples can be multiplied indefinitely.

Again, if our object is to train exactness of thought, modern languages are far inferior to Latin, which has in a unique degree, in a degree no modern language exhibits, that logical quality of which so much is said in these discussions. The Latin here, if nowhere else, was an intellectual. $\mathrm{He}$ disciplined his thought, as he disciplined himself; his words are drilled as rigidly as were his legions, and march with the same regularity and precision. Modern languages, and English most of all, are lax and individualistic ; in our grammar as in our politics we are non-conforming, dissenting, lenient to passive resisters and conscientious objectors; we have almost as many exceptions as rules. Our way is interesting and has its meritsmore perhaps in life than in language. For in the ideal language law is supreme; Reason governs its grammar and the expression is exactly measured 
and fitted to the thought which it expresses. Latin is such a language. Consider the rarity of exceptions in it. Consider how its grammar has to keep exact step with its thought, so that where the English loosely say, "If you come, you will see him," and the French, Si vous venez, vous le verrez, the Latin insists on absolute precision, marks the exact time relation of the main, and the relative, sentences, and, noting that the seeing will only take place when the action is completed, says : Si veneritis, eum videbitis, "if you shall have come, you will see him."

Consider too the strict marshalling of the Latin sentence, where there is one main verb, and only one, representing the main thought, while the other subordinate thoughts, qualifications of time and place, etc., are each in their subordinate positions, like a regiment on parade with the colonel at its head and the other officers each in his rank; and then contrast the lax discipline of the English, where nearly every verb is apparently a main verb, and it is impossible at the first glance to tell what is the main thought. Compare the English and Latin forms of the following thought: "The siege had lasted six months, and food-supplies were running low, when the consul left Capua and set 


\section{GRAMMAR \& PROSE COMPOSITION 2 I 9}

about the relief of the town." Sex iam menses durante obsidione, ita ut frumentum deficeret, consul Capua egressus oppido ferre auxilium paravit. Note as logic how vague and even inaccurate the English is. The main thought 'set about' is actually in a subordinate sentence, and even there nothing in the grammar indicates that it is more important than 'left.' "The siege had lasted ..." and "food-supplies were running low," are constructed as two main verbs, as though they were of equal importance in the thought. But I Latin sifts them all out, seizes the main thought and puts it, as the conclusion and sum of the whole, in the last sentence, and then arrays the other clauses in their due and logical subordination. It need not be pointed out that the study of a language like this is a good mental discipline, an exercise in precise expression, in correct dissection of thought.

No other language, least of all a modern language, has this rigid logical cast. Greek itself has not got it. From Greek we learn a different kind of accuracy. It is less logical, but more sensitive. Think, for instance, of its wealth of particles $\kappa \alpha^{\prime}, \delta \gamma^{\prime}, \gamma \epsilon, \delta \delta^{\prime}$ and the rest, which can express on paper shades of sarcasm, scepticism and emphasis that we express by an inflection of the voice, and 
that our written language requires some awkward periphrases to render. (ai di yuvaikes is Xenophon's way of describing the men in female dress, who were introduced into the Cadmeia to kill the Spartan harmost ; try to put this into English and note how much more clumsy is our corresponding expression.) Think of its two negatives, one for facts, the other for conceptions and ideas; of its verb, with three moods where we have two, and with a subjunctive and optative for expressing different shades of unreality or uncertainty, where the most flexible modern language has only one. English says: "If you go, I will follow"; Latin, more logical, says: "If you shall have come, I will follow." Greek by its optative allows us to express the greater or less probability of the event

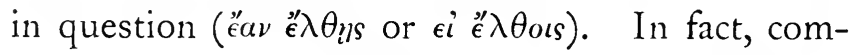
pared to any other Western language, Greek is like an organ with more stops, or, if we want a prosaic comparison, like a typewriter with a bigger keyboard.

The topic requires a book; but these few pages will indicate roughly how the classical differ from modern languages and why the latter cannot really replace the former for the purpose we are considering. No doubt there are more important 


\section{GRAMMAR \& PROSE COMPOSITION $22 \mathrm{I}$}

things in education than the study of grammar; but it is not an overstatement to say that not to know Greek is to be ignorant of the most flexible and subtle instrument of expression which the human mind has devised, and not to know Latin is to have missed an admirable training in precise and logical thought.

What then are we to say of translating into and from Latin and Greek?

Before answering this I would call attention to a curious fact. These much abused exercises are singularly unerring tests of intellectual ability. I have heard a modern history tutor say that he would be ready to ignore the marks on the history papers in a scholarship examination, and elect on the results of Latin Prose and Unseen translations ; and anyone who has had the misfortune to spend time in examining knows well that, when he comes to the Essays and General papers, he will find a very few first class papers which reveal the exceptionally able boy, and a fair number of bad ones which reveal the stupid and muddleheaded, but that the majority range from $\beta+$ to $\beta$, reaching a very fair level, but leaving him quite uncertain as to the real intellectual quality of the writers. 
He will read them and become still more baffled, and then retire to the very dull business of examining minutely the proses and unseens. It will be rare that he completes this task without discovering which of the candidates who puzzled him have brighter imaginations or more accurate or more logical minds. That is a curious and suggestive fact.

In discussing the exact value of proses and translations, let us first deal with the elementary work done in lower forms. And here let me quote from an article by a science master. "The great majority of public school boys are not going to achieve the culture which is the goal of the classics, but neither are they any the more going to feel the moral exaltation of the trained researcher whose one desire is to know the truth. . . . It is that necessary power of intellectual concentration which the public schools must above all develop, and our business is to examine how best it can be done ; whether or not this stage of education should be combined with vocational, and therefore specialised, training. The lessons we would teach are not, of course, purely intellectual ; they must needs carry a host of moral qualities with them (concentration is itself on the borderland of morals) and perhaps the whole training is better described as the power 


\section{GRAMMAR \& PROSE COMPOSITION 223}

of 'sticking' to a task, if need be, in the face of difficulties and discouragement. One thing, moreover, is certain, vocational equipment may come later, but concentration, if not acquired by the age of seventeen, is little likely to be won at all. No medium for education can be judged as to its power of developing this quality of concentration apart from the way in which it works out in practice when large classes of boys have to be dealt with. There is little doubt that the reason why the classics have held their place in education is just because they are peculiarly adapted for the efficient teaching of boys collectively. A piece of English is set to be turned into Latin. The task involves concentration, close attention to detail, and considerable logical reasoning; there are no short cuts, no formulae as in the science problem, the reasoning involved cannot be avoided by mere effort of memory as in the writing-out of a proposition in geometry; finally, the task when done can be quickly checked and the care taken very fairly judged." 1

The commonsense of this is obvious; and anyone who will try to substitute geography, history

1 Science and the Public Schools, by D. R. Pye (Physics Master at Winchester), Nineteenth Century, July, I 916. 
or science, will find by experience that they are very little use for this particular purpose of developing intellectual concentration, and that they do not exact the same amount of hard and continuous thought as Latin. To dissect a Latin sentence, to find out which is the subject, the verb, the object, and how the other words fit in (the order of the words which guides us in modern tongues gives very little help in Latin), needs close attention, and a continual readjustment between your idea of what the passage means and the sense which the grammar admits. The same is true of Latin prose. You have a number of English sentences written in our lax, coordinate English style, loose bricks that must be built into one Latin sentence. You cannot lay them side by side as they lie in the original; for Latin demands that the main thought be selected to form the main verb, and that the other thoughts be grouped round it in due subordination. So you must find the main thought, and fit the other thoughts into their proper places; a work that requires hard thinking, and a logical mind, and develops these powers, which are among the roots of success in life, and, as grown-up amateur educationalists sometimes forget, are very rudimentary in school boys. If 


\section{GRAMMAR \& PROSE COMPOSITION 225}

the reader will glance back at the specimen of Latin Prose given on p. 2 I8, and note what the translating of the English into Latin involves, he will see what is meant.

Sixth form prose and translations are the same thing in a much more advanced and elaborate form. Here is a specimen taken from the Times' leader on the death of Queen Victoria: "The extension of political interest among the masses of the people has brought into existence a great body of politicians, who are acutely familiar with constitutional forms and processes, but have little conception of the personal element which should be behind them." Now turn this woolly bit of English into Greek, and you may have a rendering which translates literally as follows: "Since the masses have taken a greater share in the state a large crop of politicians has appeared who have an exact knowledge of prytanies and preliminary votes and the forms of the constitution, but do not understand that we need besides men to administer them." " That is not, nor is it meant to be, good

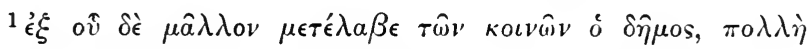

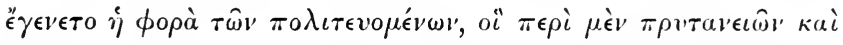

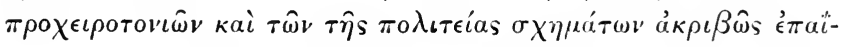

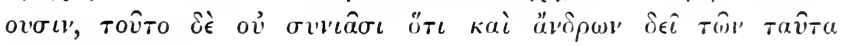

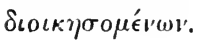


English, but it shews several things: first, the Greek language's hatred of abstract phrases, which it immediately turns into the concrete, making " extension of political interest among the masses

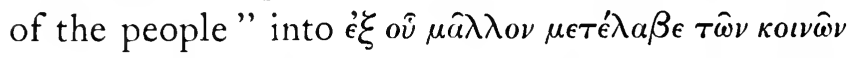
$\delta \delta \hat{\eta} \mu o s$, and clearing up "personal element that must be behind them " into something much less indefinite; the cloudy shapes of the English take a harder outline, and become substantial, solid things. Second, it shews that doing Greek prose is, largely, rethinking in new and concrete language what English has given us in a different dress, and very often, as in the passage above, thinking it far more clearly. Most people who have tried it would agree that an hour of this work takes more out of a man than an hour of any other intellectual exercise; and it is not surprising if this is so. For almost every muscle of the mind has been exercised: imagination to grasp the real meaning in a new and concrete form, accuracy to let slip no ounce of the original thought, logic to fit the parts together in a coherent whole, besides the aesthetic sense to give it proportion and shape. The result in itself is, in a sense, worthless, but the process is invaluable; and to condemn Proses because bits of artificial Greek and Latin are of no actual use, 


\section{GRAMMAR \& PROSE COMPOSITION 227}

is like ridiculing physical training on the ground that it is waste of time to spend an hour putting the body into uncomfortable positions.

Translation into English is a closely allied intellectual exercise, which reinforces composition, but is not a substitute for it. It does not demand the same recasting of thought as is required in an attempt to turn our abstract English style into Latin and Greek, and is therefore neither so difficult nor so testing. On the other hand, it is perhaps an even better discipline in minute and accurate observance of language. The use and position of the article in Greek, the tiny particles with the various shades of meaning which they carry, compel a close and constant attention, and any carelessness is easy to detect. The dissection of the complicated structure of a Latin and Greek sentence-so much more complicated than any sentence in English-needs observation and thought; and the slight differences in meaning between a Latin or Greek word and its nearest equivalents in English have to be noted and rendered. Let anyone translate: Omne aevum ferro teritur. .. . Canitiem galea premimus. . . Exercita cursu flumina... . Sanguineisque inculta rubent aviaria bacis.... Venatu invigilant pueri silvasque 
fatigant. . . Iam pulvere coelum stare vident. . . . Victoria Graium haesit; if he tries to get words that an English poet might use, and that yet catch the exact shade of the Latin, he will understand what a training translation affords, not only in resource and command of English, but in sympathy, insight and delicacy of perception. A boy doing an unseen is working, so to speak, in a laboratory of language, analysing, measuring, weighing, compounding, the subtle substances of which it is composed.

"We regard," says Mr. J. L. Paton, "Latin prose as a real piece of strenuous work; to tackle it requires mental grasp, it probes into anything that is slipshod in a boy's learning, it calls into play all a boy's knowledge, and shows whether he has made it really his own; it needs all-round alertness and resourcefulness of mind; we regard it as far more heuristic than any method of science teaching as yet proved feasible in schools, and the product we regard as the product of a boy's own mental effort in a sense which attaches to no other piece of his work, and as an index of the real inward quality of his mind." I If this is true,

${ }^{1}$ Board of Education, Special Reports on Educational Subjects, vol. 20, p. ${ }^{1} 5^{6}$. 
and I have tried to shew that it is so, we have a more than sufficient justification for the presence of Latin Composition in education. And if anyone, still unsatisfied, asked what is the practical use of it all, the defender of compositions would say: "Whatever our business, we shall need to use words, and there is no better way of learning to use them. Not that Latin Prose will teach us to write good English; a glance at the books of some great scholars would soon undeceive anyone who thought that. But it trains us, as nothing else trains, to be precise in our use of language, and to exact precision from other people-an uncommon but very important gift. For we shall be often writing letters in which we want to be sure what precise meaning our words carry, and to what exactly we are committing ourselves. And we shall be receiving letters and hearing speeches, the exact meaning of which it may be important to discover; and as we scan them carefully, in order to guess what was really in the mind of the speaker or writer, where he was putting us off with a phrase, or evading a point, or wrapping up a weakness of his own in words, or slipping in a qualification, or using language which might be interpreted in more ways than one-we are simply 
doing what we learnt to do when we turned Latin into English. The Press, if no one else, will always be throwing phrases over us-Reaction, Efficiency, Scientific Method, etc.-and before we take these flies, we shall want to know what they are made of. Otherwise we may get hooked on a phrase which has no fact behind it. Half the work of a Latin Prose is analysing conceptions and seeing exactly what they mean. (If we wish to test a bit of English prose or poetry, and see how much of it is thought, how much mere words, and how it hangs together, there is no test in the world so effective as turning it into Latin or Greek: that soon discovers the weak places. Could there be a better testimony to the intellectual value of Composition than this?) In it we are continually having to translate words like ' fanaticism,' 'heretic,' 'sympathy,' 'heroism,' 'compromise,' 'religion'; and since there are no Latin words exactly corresponding to them, no convenient synonyms into which we can shuffle them, without troubling as to the precise idea behind, we find it necessary to think exactly what they mean. And we have not only cleared up our thoughts on a point of modern dispute, when we have decided whether to translate ' religious educa- 
tion' (simply disposed of in French as 'l'éducation religieuse') by pueros pietate erga deos imbuere, or pueros de deorum natura certiores facere, but we have been practising an art that will help us later in sizing up the phrases of politicians and press.'

'But is there no other way of learning this art?'

Accuracy in language can only be learnt from the use of language. We cannot learn it from science, which teaches accuracy, but only in its own sphere. So much the psychologists have established beyond a doubt. The most precise chemist or mathematician does not necessarily keep his precision beyond the sphere of chemistry or mathematics; as, indeed, we can discover without going to the psychologists. It is therefore no use looking to mathematics or science to help us here.

Nor can French or German take the place of Latin and Greek. German is a first, French a second, cousin of English, and the family likeness is so strong that it is child's play to translate into them compared to translating into Latin or Greek ; it can almost be done without understanding what the English means. Take the sentence put into Greek on p. 225 : its translation was difficult and 
called for close attention and hard thought. Now put it into French. It is an easy task; no thinking is wanted, only a half-mechanical knowledge of vocabulary and idiom. It goes in a straightforward way something like this: L'extension des intérêts politiques parmi le peuple a fait naître un grand nombre de politiciens, auxquels les formes et les lois de la constitution sont familières, mais qui n'ont qu'une idée imparfaite des éléments personnels qui devraient être leur soutien.

It is easy to see why its translation into Latin and Greek is so much harder. In them we must know much more than the necessary vocabulary; we must arrange our words on a new principle, we must rethink them, and when we have to deal with 'personal element,' instead of putting it down as 'éléments personnels' we have to consider what it really means. Here is another instance to shew how poor an exercise of thought French prose is. Translate into French and Latin 'a romantic affair' and 'a romantic woman.' In French the business is done at once, and the difficulty is decently veiled in 'une aventure romanesque,' ' une femme romanesque,' but when we come to Latin we find not only what 'romantic' really means, but also that it means two totally different 
GRAMMAR \& PROSE COMPOSITION 233

things in the two cases. 'A romantic affair' may be res mira et inusitata, if we interpret romance here as a strangeness and unusualness ; 'a romantic woman' may be mulier novitatum deliciis deaita, if we are thinking of some one with a whimsical fondness for out-of-the-way experiences. If we try to translate 'romantic poetry,' while la poésie romantique will serve us in French, Latin takes us far afield for an equivalent. It compels-French dispenses with-hard thinking to find the real idea concealed behind the word, and, educationally, it is therefore far more useful. Does anyone really doubt that Latin Prose exercises the sinews of the mind as well as gymnastics exercise those of the body, or deny that to attempt to get the same result out of a modern language, is like supposing that the muscles will be satisfactorily developed by changing from one chair into another?

The study of Realien or the subject-matter of books, is, of course, highly important ; but it does not give the command over words, the analytical power of which we have spoken. No education can ignore the analysis of thought as expressed in language, and no method of practising it has yet been devised so effective as Latin and Greek Composition and Unseens. It would be anything but 
a gain if these disappeared or were greatly reduced. Ben Jonson has mentioned a danger, against which they are the best safeguard. "Some that turn over all books, and are equally searching in all papers; that write out of what they presently find or meet, without choice. By which means it happens that what they have discredited and impugned in one week, they have before or after extolled the same in another. Such are all the essayists, even their master Montaigne. These, in all they write, confess still what books they have read last, and therein their own folly so much, that they bring it to the stake raw and undigested; not that the place did need it neither, but that they thought themselves furnished and would vent it." 1 No one can be a College Tutor for long without meeting, even under the present system, persons who have a general interest in ideas, and a considerable power of handling them, but are vague, dilettante and at the mercy of phrases. For these Prose Composition, with its precision and its compulsion to think hard and clear, is the best of medicines; it will not let you play with phrases, but demands to know exactly what you mean; it will not let you slur

${ }^{1}$ Timber, lxv. Nota 6. (The grammatical peculiarities are Ben Jonson's.) 
over a meaning, on pain of immediate detection. It is a perpetual discipline of accuracy in thought and word and a rod for the back of journalistic chattering. ${ }^{1}$

In this chapter I have been dealing indirectly with the one really strong argument against the classics - the doubt whether the time spent in learning the languages is compensated by the results. No critics who have a real knowledge of Latin and Greek doubt the excellence and value of their literature and thought, but they might ask if the labour of disinterring them is worth while. That is a question we must answer by computing in our minds gain and loss, and in doing so, we cannot expect a result as definite as if we were weighing pounds and ounces; education deals with imponderables.

The case for the classics is cumulative; no single item may turn the scale, and yet all together they may do so. Review the arguments in turn.

${ }^{1}$ Defenders of the classics are often suspect for crying their own wares. Such a charge cannot be made against this particular defence of composition; for the writer's whole interest is in the subject-matter of Latin and Greek, and though he gratefully acknowledges what proses have taught him, he would be thankful if he never had to write or correct one again. 


\section{CLASSICAL, EDUCATION}

Against the difficulty of learning Greek and Latin set the fact that without them we cannot have a scientific knowledge of much in our own and other modern tongues, and that Latin is a real help in the learning of these; that Latin and Greek are admirable schoolmasters in the study of human thought as expressed in language, and that they give a mental discipline and gymnastic of thought, absolutely necessary in education, and not to be got so completely and satisfactorily in any other way. Add that if we know nothing of Greece and Rome we are ignorant of our origins, and lose the key to much in our own literature and much in the modern world; that we are cutting ourselves off from the two greatest and most influential civilisations on which Europe is built up, and from two literatures, of which one, in completeness and excellence, has never been surpassed; that we are declining intimacy with poets and pioneers of thought, among them some of the greatest masters of the human mind; that we are refusing the educational advantages which come from the simplicity and completeness of Greek history and literature; and that we are neglecting to provide ourselves with the only independent standards there are, with which to compare and test our own 


\section{GRAMMAR \& PROSE COMPOSITION 237}

ideals and civilisations. These advantages have kept the classics in our higher education, and we must consider very seriously whether we shall become a better or more efficient nation by sacrificing them. 


\section{CHAPTER VII}

\section{REFORMS}

My love for any place, person or institution is exactly the measure of my desire to reform them.

Thomas Arnold.

Many of the critics of a classical education have never had it; but for its other enemies, its teachers have themselves to blame. If Latin and Greek are what they are, and we have taught them, and at the end our pupils cry, "Away with them," the fault is not in the subject taught, but in us ; and anyone who has been through a big public school or university, and would then like to turn the classics out of education, is a standing indictment of his teachers. In this chapter it is proposed to consider where we have come short, and what we can do to make matters better. I shall not attempt to discuss secondary education as a whole, or even the relation of classical to other subjects. I shall, however, assume that Greek and Latin, for those 
who continue the study of them after the age of fifteen, should have an important place in a curriculum-unless they are thoroughly learnt they had better not be learnt at all-and simply consider some changes for the better which might be made in their teaching. At the same time we can glance at a question which readers have probably asked themselves-how far boys really get from the classics all that has been claimed in the previous chapters?

The main problem is threefold: first there are boys up to the age of fifteen and sixteen and boys who never get beyond a lower fifth ; then there are those who reach sixth forms and get facility enough in reading ancient languages really to appreciate them as literature; finally there are classics at the University. Clearly these are three different questions. Small boys (still more the drudges or lotus-eaters of seventeen and eighteen, who linger half way up a school) get few of the advantages of the classics which form the subjects of Chapters III.-V. in this book; their minds are not developed enough to appreciate the genius of Greece and Rome, or to be interested in ideas or problems; and in any case, they hardly know enough of the language to get at them. Like the 
unferried spirits in Hades, they flit along a rather barren beach, eyeing the promised land across the water, and not always "stretching out their hands with longing for the further shore." On the other hand, the Elysian plains are in part accessible to those who reach a sixth form; and they are fully open to University students. There is nothing, for instance, in this book, except, perhaps, Hippocrates, which should not be common property for anyone who takes the classical schools at Oxford; if it is not, he has only himself or his tutors to blame.

What then of these three classes?

The small boy and the laggard.

No one should want to keep the laggard at the classics, if by the age of sixteen he has shewn no taste or capacity for them. Plato has described his condition precisely. "You can never expect a person to take a decent delight in an occupation which he goes through with great pain, and in which he makes small progress with great exertion?

No, it would be impossible.

Again, if he can remember nothing of what he has learned, can he fail, being thus full of forgetful-. ness, to be empty of knowledge? 


\section{REFORMS}

No, he cannot.

Then will not his unfruitful toil compel him at last to hate both himself and his occupation?

Doubtless it will." 1

It is absurd to keep anyone in this condition at Latin and Greek. He had much better make the most of what lies on his own, and, as we think, the wrong side, of the Styx. One of the great blemishes in the public school education of the past, which has brought more obloquy on the classics than anything else, and which a great deal has already been done to remedy, is the retention of such boys at work for which their minds were unfitted. It made them "hate themselves and their occupation," and left them without an education. It ought to be a first aim to prevent these abuses for the future, and in especial to avoid diverting boys with mechanical or scientific tastes, who have no aptitude for linguistics, into studies that will be barren for them.

On the other hand, unless he is exceptionally unsuitable, a boy will do well to learn at least Latin till the age of sixteen. He will gain the advantages mentioned in Chapter VI., he will be learning a language which will help him with modern lan-

$$
{ }^{1} \text { Republic, }+86 \text {. }
$$


guages, and throw light on much in English that would otherwise be obscure : he will get the mental training given by composition, translation and grammar, at the age when it is most necessary. Some such training he must have; nothing can make it fascinatingly interesting, and substitutes for Greek or Latin are likely to be less effective and equally offensive. Also it should be possible when a boy is sixteen-it is often difficult earlierto tell where his real gifts lie. Nor, up to that age, is the work such drudgery as we might suppose. I think most teachers would agree that small boys, on the whole, enjoy translating into and from Latin. It is a sort of jigsaw puzzle with words, pulling them to pieces and fitting them together, and it interests them as such; it requires all their attention and uses up most of their intense mental activity; thus it occupies their minds, which is half the difficulty with them. Boredom and loathing sets in much later, when they are seventeen and find themselves in the lower fifth doing subjects in which they will never get beyond a certain point, and with nothing to satisfy a mind that has grown and is calling for some more suitable food. This is the age when the burden presses, and when they should be freed from it. 
No doubt there is drudgery in the early stages of learning the classics; but it is less felt by boys than by grown-up sympathisers, who realise how they would hate struggling through a text at the rate of twenty lines an hour. Here (as in some social questions) the onlooker imagines sufferings which the victims never feel. Boys who have not made much progress in a language appreciate its contents far better than we suppose. I can still remember, when I had only learnt Greek for a year, my pleasure in hearing a certain master sonorously

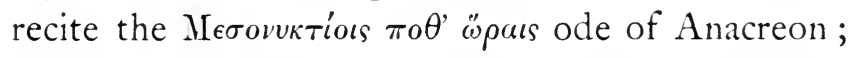
and later, but still at my private school, the delight of reading in some selections from Plato the myth in the Republic, and a certain passage from the Timaeus, which I have never seen since, till I looked up the reference to-day, a myth of the creation of fish from the most dull and ignorant men, whose impurity made them unfit to breathe the pure air of heaven. ${ }^{1}$

Small boys are not interested in ideas, nor in big historical movements. They are generally rhetoricians, and like rolling sentences and a rather flashy sort of writing. The picturesque, the dramatic, what they can see and imagine themselves a part 


\section{CLASSICAL EDUCATION}

of, pleases them in literature; but they can enjoy at the age of thirteen, as well as ten years later, the strange adventures of Er, son of Armenius, and see, perhaps more vividly than their elders, the treeless plain through which the spirits marched in "terrible, choking heat," and imagine the midnight thunder and earthquake, amid which Er saw those spirits "suddenly borne up to rebirth, like shooting stars." 1 It is a great mistake to suppose that we cannot enjoy the classics long before the stage when they can be read "with our feet on the mantelpiece."

On the whole then, except for setting free boys with no capacity for the subject, where they have not been set free already, the first stage of classical education may be left alone. It is as satisfactory as most things in education are likely to be. The important question, when Greek and Latin should be begun, can only be settled by schoolmasters; but to an outsider with no experience of private schools, it seems as if it might be better to postpone the second classical language to a later age than is at present usual.

The serious difficulties begin in the second ${ }^{1}$ Republic, 621. 
stage, that of the sixth form boy, and the third, and last stage, the University. Here we come to the weaknesses of English classical teacning. In a sixth form, and still more at the University, we have to deal with boys whose minds are so developing that they can begin to appreciate the real greatness and value of the classics, and whose growing grasp of the languages enables them to cover with fuller understanding a wider field. Obviously, as these changes take place education must be progressively adapted to them, by setting the student work, which is not merely harder, but which is adapted to his new interests. It is not enough that he should pass from Euripides and Livy to Aeschylus and Tacitus, if he reads his new authors from the same point of view as the old; any more than it would be enough simply to give a richer form of milk to a baby which has got its teeth. A new kind of food is wanted to correspond to the new organs which are developing. The merely formal training in the classics which is suitable to a boy of fifteen, must be supplemented and finally largely replaced by the study of their ideas, their lessons, their meaning to the modern world. The changes will come slowly, adjusted to the changing capacities of the student, and they will not be 
complete till he reaches the University. But by that time they should be finished, the 'childish things' put away, and the balance shifted from the formal training to the contents of the classics. When we have to teach young men of eighteen and over, if we still lay the chief emphasis on grammar, composition and scholarship, we have ignored the development of their minds and interests, and forgotten to change their mental food.

How do our schools and universities stand in this matter? They differ. The big public school which the author knows best seems to him, as far as the classical scheme in its sixth form goes, to need little or no change. Modern history and divinity have an important place in its teaching: science is done by everyone in the lower division of the form : the study of English literature is encouraged, without regular class work, through an annual prize which includes papers on Shakespeare, on literature since I 837, and on certain set books: an English essay, an English historical essay, and a prize given for the study of some aspect of Greek or Latin literature, life or art, admirably supplement the ordinary classical training. If we assume that the classics are to be the pièce de résistance in 


\section{REFORMS}

education for the boys whom they suit, this course would seem a satisfactory curriculum; it avoids narrow specialism, and makes definite provision for the growing interest in Realien, in the contents of the classics as opposed to their form, in things as well as in words. On the other hand, there are schools from which boys come knowing little English literature, little history, and very little of the classics except how to translate into and from Latin and Greek. Schools as bad as these are few, and so far as the writer's experience goes, the new big secondary schools, which send pupils to the Universities, are not among them. Still, the weakness of English classical teaching is on the side of Realien. ${ }^{1}$ These tend to get swallowed up by scholarship. Schools are apt, in their attention to a side of the classics which is absolutely necessary, to forget other sides, and to send up boys who have mastered the form of Latin and Greek, but not their contents, who can translate them, but have an insufficient idea of their message. General papers in scholarship examinations make for the most part dismal reading.

${ }^{1}$ I use this convenient German word to mean the subjectmatter of the classics as opposed to their form, to grammar, scholarship, etc. 
The remedy for this evil, where it exists, is a change, less of curriculum than of the angle of view. The same books may be read as now, but with very different results, if, instead of thinking only of grammar and scholarship, we think of their contents, their author, and the civilisation which produced them. But it will be difficult to secure this reform without some change in the Universities.

The University is the key to the whole position, for anyone who wishes to go there is obliged to conform to her standards and demands. The colleges award scholarships and set the papers for them ; and a school that wishes to get scholarships is obliged to consider what these papers are like, and to frame its teaching, so that any candidates it sends up can answer them. And unfortunately, the University, ${ }^{1}$ both in its classical scholarships and in Honour Moderations, pays little attention to the mental development of boys of which we

${ }^{1}$ I can only speak about Oxford, but from what I know of Cambridge classical scholarships, I imagine that my criticisms here would apply to the sister University. The Classical Tripos is very different from Honour Moderations at Oxford and, to judge from Mr. A. C. Benson's criticisms, has evils of its own. 
spoke above. It still lays a very predominant emphasis on the linguistic side of Latin and Greek, and teaches and examines in them from an angle of view much more suitable to boys of fifteen than to young men of nineteen. We will consider the point more closely. The examinations for classical scholarships generally comprise papers in Latin (I) and Greek (I), Prose ; in Latin (I) and Greek (I), Unseen Translations ; in Latin (I) and Greek (I), Verse ; and in French and German (I) (the three last are optional; the French and German paper counts for very little, and the verse papers do not affect the result, unless a candidate does particularly well in them). There is also a General Paper and an Essay. Now it is obvious how heavily this scheme of papers leans towards knowledge of the languages and away from knowledge of their literature. Four compulsory and two optional papers are linguistic; one only, the General Paper, gives a boy a chance to shew what he knows of the subject-matter of the classics, and in practice it generally shews that he knows very little, but that his master has recently made him do an essay on the Homeric problem or recent discoveries in Crete, or some other profitable topic that is likely to be set. Nor is it in any case a good test of 


\section{0

general knowledge of the classics, for only a few of its questions relate to them. That the papers shew this linguistic bias is not because the colleges are attracted to proses and translations, as by a sort of original sin. Partly, no doubt, it is tradition; English education has always been noted for the excellence of its pure scholarship. But partly it is because these methods give, not necessarily the best results educationally, but the safest test of a boy's ability. No one can really cram proses and unseens; but a second-rate, yet very industrious, boy can get high marks on any prepared work by sheer labour. So prepared work is an uncertain guide in a scholarship examination ; it may give you the most laborious or the best crammed boy instead of the ablest one. Hence the colleges naturally prefer a test which will better reveal ability: and the schools having to follow their lead, there is no chance in present circumstances of reducing the amount of composition. The total result is that the schools have every inducement to specialise on pure scholarship, and hardly any to pay attention to the contents of the classics as well as their form-to say nothing of subjects other than Latin and Greek.

The most satisfactory classical scholarship 
examination is that for close Winchester scholarships at New College, where, in addition to the ordinary scholarship papers, the candidates have to do a period of history (generally modern), a divinity paper, and set Latin and Greek books. This is a check on excessive specialisation in classics, and on an undue predominance of pure scholarship. It might well be a model for other similar examinations, though even in it composition has perhaps an excessive place.

But the University's influence is felt through the curricula for its degrees as well as its scholarship examinations. The full classical course at Oxford has two limbs: Honour Moderations, of which the subject is Greek and Latin literature, and "Greats," which includes Ancient History and Philosophy. The degree, in fact, is awarded on three groups of subjects: literature, history, and philosophy. It is an examination characteristic of Oxford, and of which the University is justly proud. The most stimulating and valuable side of it is the philosophy group ; the least satisfactory is the literature, though it has great merits and still greater possibilities. Its merits are that the student reads large tracts of great literature, including the 
whole of Homer and Vergil, and so becomes familiar with some of the great writers of the world. Its weaknesses are that: (I) he reads most of Cicero's and Demosthenes' speeches (which is as if one read all Burke or all Bossuet and knew nothing about the rest of English or French oratory): they bore him, he has too much to read to think what they mean, and he knows nothing of the rest of ancient oratory. (2) In those books which he reads with attention to grammar and text, exigencies of time do not allow his knowledge of their subject-matter to be properly tested in examination, and he masters the translation, learns some grammatical and textual points by heart, and for the real contents of the books is in much the same state as the hero of Mr. A. C. Benson's House of Quiet. Mr. Benson is writing of Cambridge, but I have omitted any phrases which are not applicable to most men who have just taken Honour Classical Moderations: "I took up the Classical Tripos, and read, with translations, in the loosest style imaginable, great masses of classical literature, caring little about the subject-matter . . . with no knowledge of history, archaeology, or philosophy, and even strangely ignorant of idiom. . . . I did indeed drift into a First Class, but this was 
merely due to familiarity with, rather than knowledge of, the Classics; and my ignorance of the commonest classical rules was phenomenal." 1

In the teaching for the examination, if not in the examination itself, composition takes too large a part. The time most undergraduates spend with their tutors is almost entirely occupied in the correction of compositions and unseens; essays on the contents of their books are comparatively rare. (4) The study of grammar and textual criticism is thoroughly unsatisfactory. It is not necessary for an undergratuate to know the theory of the grammar of Latin and Greek, or to have studied those languages as specimens of human thought trying to express itself in words. But if abnormal constructions come in his books, he knows that these may be set in his examination, and therefore with weary industry he commits to memory the explanations of them given in his notes. It is much the same with textual criticism. The result is that an undergraduate who has finished "Mods" has had an admirable mental discipline and has read and can translate well a number of works of genius, but that he has had no connected view of the Greek or Latin literatures, and that if you asked him in ${ }^{1}$ P. +3 . 


\section{4

what their genius consisted and what was their contribution to the world, he would give either no reply or a very inadequate one. In these respects he is as far behind a German undergraduate of the same age as in scholarship he is ahead of him. Thus in the chief purely classical examination of the University, as in its classical scholarship examinations, the weight is thrown heavily on the linguistic side of Latin and Greek.

This is still more so with the Ireland and Craven and Hertford scholarships, which, in journalistic language, are the 'blue ribbons' of classical attainment in Oxford, and which are won by the ablest classical scholars of the year. Take the first of these ; it has ten papers: four of them are translation ; four at least-generally five-are prose and verse composition ; one is a general paper, including questions on all departments of classical study, grammar, inscriptions, textual criticism, history of scholarship, comparative philology, history of religion, literature, etc., etc. In other words, fourfifths, and often nine-tenths, of the examination are linguistic, and every other aspect of the classics is crowded into a single paper of three hours. Thus the crown and summit of our classical examinations demands practically nothing of the best students 


\section{REFORMS}

we have, except to be able to translate into and from Greek and Latin. (As the papers are generally set, the best hope of succeeding with the unseens, is to have read, not whole authors, but picked passages, chosen for their difficulty and with a decided inclination to Callimachus and obscure Alexandrians, Statius, Pliny the Elder and other writers of the second and third rank.) And so an examination which might be used to encourage an undergraduate to get a wide survey of Greek and Latin culture, thought and literature, and a strong hold on their significance, serves simply to chain him to their purely linguistic aspects.

It is the English theory, or rather-for in this country traditions take the place of theories - it is the English tradition, to attach great weight to scholarship, and it would be a serious mistake to suppose that this is wholly bad. On the contrary, it has great merits. For one thing, it is much to be able to translate easily and accurately what we read. For another, the hard thinking, the precise and careful weighing of words that it involves, are an excellent antidote to the flaccid habit of mind which comes from continually dealing with ideas, and against which in any reform we shall have to guard. Our big public schools have always driven 
hard at translation and composition; they have taught boys really to know the languages-which is a great thing-and in doing so they have obtained the mental by-products which result from linguistic training. Under iron discipline on a difficult material they have accustomed their pupils to hard and continuous work ; and they have produced a certain fineness of perception and a habit of hard thinking, which follow constant attention to minutiae of scholarship, and the companionship of great writers and masters of form. This is a considerable achievement, both in itself and educationally. It has had, among other virtues, the great virtue of thoroughness: and though there may be better forms of education, there certainly are many worse. Its fruits are to be seen on the front benches of the Houses of Parliament and in the Civil Services; and whatever defects of character and will their occupants may have, no one would accuse them of sloppy intellects. They compare favourably with the governing bodies of other nations; and, on the whole, they are the products of the public schools, with their classical course. It would be a disaster if we went to the other extreme, neglected translation, displaced prose compositions, and went entirely for the study of 
Realien; our education would then be more unsatisfactory than it is at present. But we might with advantage consider whether there is not something in the view that a boy's education should change materially as his mind develops, and that when his capacities allow, the balance should be shifted away from scholarship and grammar to giving him a real knowledge of the contents of his books, of the genius and personalities of his authors and of the nature and significance of Greek and Roman culture.

The remedy, especially in the schools, is not so much a big change of curriculum as a change of emphasis, less stress being laid on scholarship, more on the contents of the books. ${ }^{1}$ Verses might well go altogether. They have largely disappeared

1 At Oxford Honour Classical Moderations might be made a really excellent education, if proses were reduced to one, at most, a week, if the Demosthenes and Cicero were cut down, if the $B, C$ and $D$ groups in the present special books were remodelled on the lines of group A, or if the special books were arranged so as to form special subjects (such as The History of Roman Elegy with Propertius, Tibullus and some Ovid); more provision should be made for testing the knowledge of subjectmatter, and grammar and textual criticism should recede into separate, and optional, papers. The Ireland and Craven examination might be improved by devoting four of its ten papers to Realien. 
already, and many boys do not even offer them in scholarship examinations. The chief arguments for them are that they are a training in taste, that Dr. Arnold, after being against them, was converted to them when he went to Rugby, and that a great many boys enjoy doing them. But they are peculiar to this country; those who cannot do them are not visibly the worse for it ; they distract the attention still further from Realien, and it is impossible not to feel that the three or more hours a week which they cost might be better spent. Further time might be gained by a reduction of proses. At present in most schools two proses are done a week, when for educational purposes one would be sufficient. They are set less on their own merits than because proses 'pay' in scholarship examinations; and though, for reasons given on page 227 , I do not think that unseen translations into English can entirely replace them, I quite agree with Mr. Pickard-Cambridge ${ }^{1}$ that an increase of these (which would take much less time) at the expense of prose would be desirable. There is no better intellectual discipline and no better exercise in the choice of the right English word, than translations from Greek and Latin.

${ }^{1}$ Education, Sience and the Humanities. 


\section{REFORMS}

Another point which needs attention is the teaching of grammar. Grammar may afford a study of the human mind trying to express itself, and its teaching is often defended on these grounds. But it is very rarely taught in that way. It is learnt, on the dogmatic ipse dixit of the grammar, as a string of rules which have no visible cause or obvious meaning, but simply are. In the earlier stages it is necessary to teach thus: but the time soon comes when boys are interested in explanations and capable of understanding them, and it is a mere dulling of intelligence to keep them in a drill room atmosphere, where words of command are given and no one expects to do anything but obey them. Yet not many sixth form boys know why Latin has five declensions, or how it compares as a language with Greek or English, though in a sense they know their grammar admirably, and can give the constructions of $\pi$ iv or the conjugation of a verb in $-\mu \iota$ without faltering. Things have improved greatly, as anyone can see who compares Professor Sonnenschein's grammars with those of the past ; but the schoolmaster is sometimes worse than his grammar, and the grammar has not yet been written which not only gives the rules and forms of Greek and Latin, but also 
explains in an interesting way how they came to be. How mechanical our teaching is, is shewn by the schoolboy's ignorance of the meaning of the grammatical terms which he uses so glibly. Not twenty per cent. at most schools could explain the origin of the terms, supine, accidence, declension, accusative absolute, participle, tense, etc. That in itself is not very serious, but it is a sign of parrot learning to use words of which you do not know the meaning. (It may be added that this habit of mechanical teaching is not confined to the classics; most people have learnt a good deal of Euclid before they realise how it got its name; still more remain ignorant to the end why algebra is so called, and a large number study those two branches of mathematics without the least idea why they should do it, or what on earth is their practical use.) In the University stage particularly, the teaching of grammar requires radical reform. At present it consists almost entirely in explaining abnormal constructions. It is as though we trained students of anatomy by exhibiting to them hunchbacks and other deformities, defending ourselves by saying that this would test, by contrast, their knowledge of the perfect human form. Grammar papers of 
this sort might well disappear altogether, and be replaced, if at all, by a methodical study of the subject. But the average student is not interested in grammar; it distracts his attention from other sides of the subject, and in his University career it should be a voluntary study. He will always be secured in a knowledge of normal grammar by having to translate into and from Latin and Greek.

But, as always in education, the essential thing is the teacher, and the success of a classical education depends less on our curriculum than on the use we make of it. And here the first thing, if we are to get their secrets from Latin and Greek literature, is ourselves to know what they are and then consciously to demand them. At present, so far as concerns the contents of the classics as opposed to their form, we are often like people who go to a big and famous picture gallery without any definite idea what they want to see there. They wander from room to room, glancing casually at whatever takes their eye, and come out, having enjoyed their visit and having missed many of the best pictures. They would not have done the latter, had they known beforehand what they wanted to see. The way in which the classics are read at schools and 
elsewhere is apt to be equally unmethodical and haphazard. We translate our texts and study our notes and finish our Greek play or speech of Cicero without realising how much there is in them. Could we fill in the stage directions in Sophocles' Ajax? Have we seen before our eyes the scenery in which the action takes place, and the characters, and their gestures and movements on the stage? Have we a clear idea what virtues entitled Odysseus to the favour of Athene, what Sophocles thought of the egoistic savage who gives his name to the play, and of his suffering wife, and what light these three characters throw on Greek ideals of womanhood and manhood? When we read the Pro Sulla, can we say exactly where Cicero's argument is weak and how he veiled its weakness from the jury, or what light the speech throws on a law court in Rome, or on the government of the provinces under the empire? We need, more than we do at present, to determine beforehand what Greek and Latin can give us, why we read them, how they differ from modern literature, where and how they correct our vices, where we have gone beyond them: if we are clear on these points, our walk through Greek and Roman literature will run less risk of degenerating into an unintelligent 
saunter. No doubt we shall get some good from sitting down casually and reading Cicero; but it will be far more pleasant and profitable, if we first remember that none of all Cicero's extant speeches was unsuccessful, and then ask ourselves what qualities gave him this success, and what a modern speaker can learn from him, noting in each speech the weakness of his case, and how he conceals it, its strength and how he emphasises it, and making clear what we are learning, as we read, about contemporary life, Roman ideals, etc., etc. There is nothing in this which requires exceptional gifts; to read thus is simply to read intelligently and deliberately.

Similar intelligence might be shewn, and often is not, in the choice of books for reading. As it is, a boy reads Thucydides, or Juvenal, or the Electra of Sophocles. How much more would he gain from these if with Thucydides he read Tacitus or Herodotus for a contrast in method and spirit; if, to correct Juvenal's view of Roman society, he studied at the same time the younger Pliny, or the life of Agricola, or some similar work that gives the other side of the picture; if, with the picture of the Greek in a Roman family, which Juvenal paints from the point of view of a Roman client, 
he combined Lucian's sketch in De Mercede Conductis of the same subject as it seemed to a Greek ; if he contrasted the treatment of the Electra story in Aeschylus and Sophocles and Euripides, instead of reading the three plays in isolation. One might multiply such instances indefinitely; the present habits of most schools give ample cause for criticism on this head. ${ }^{1}$

Education, and with it the classics, are suffering from a disease which affects everything from religion to the scenery in which we live. Familiarity breeds, not contempt, but want of curiosity. We are so used to the 'supine' as a grammatical term that we never think of asking its meaning; Cicero has been so long in the curricula that it never occurs to us to ask why he was the greatest advocate in antiquity. If we met the word 'supine' or came across Cicero for the first time, it would be otherwise; we should be curious and have all sorts of questions to ask, for they would be novel and strange. The problem is (as in reading the Bible or in walking down the High

${ }^{1}$ Examples of methodical reading of the classics are given in Mr. Paton's report, The Method of Teaching Classics in the Reform Schools in Germany (Board of Education Special Reports on Educational Subjects, No. 20). This volume ought to be, but is not, in the hands of every teacher of the classics. 
Street of Oxford) to recapture the freshness and turn the familiar into the new, and replace apathy by wonder. And unfortunately there is no easy receipt for this. Only a quickening of the imagination can help.

After we have said this, it may seem a bathos to suggest that much would be effected if the use of annotated editions disappeared, or were at any rate restricted. But, in fact, they are the greatest enemies of intelligent reading, for they give us cut and dried answers to all the questions we ought to ask, so that, far from finding the answer for ourselves, we probably do not even ask the question; we simply learn the note. The first climbers on the Matterhorn needed all their strength and wits and mountain-craft to find their way to its summit, and thought it the most difficult ascent of all; the modern tourist, by ropes and ladders and the unmistakeable tracks worn on its rocks, finds it little more than a walk to its summit, and, if he is at fault, an experienced guide puts his feet into the right holds. Something similar has happened to the classics; they have well-worn and clearly-mapped routes, and the days are long past when Renaissance scholars laboriously worked out their meaning. Yet if we are to read them with 
full profit, we should aim at recapturing something of the freshness with which Guarino or Poggio read their Greek and Latin MSS. If we realised and tried to solve their difficulties for ourselves, and did not always turn to the ready-made answer in the notes, instead of being rather jaded tourists, we should catch something of the fresh interest and excitement and mental energy of pioneers.

It is obvious in all this, as always in education, that the real problem is to find or make the ideal teacher. And by that is meant not merely the man who can keep order and impart what he knows, but what Nietzsche calls a moderner Mensch. "Our public schools," he says, in words which, if we substitute 'scholar' for 'savant,' might apply to England, "tend to educate savants (Gelehrte), because the teachers are savants. These savants are not in the least in a position to defend classical antiquity in the school. 'They shelter themselves behind the formal value of Latin. . . The classical teacher is merely a specialist, so long as he is a savant. The greatest help to becoming receptive of antiquity is, to be a modern man, and genuinely united with the great moderns." 1 And if anyone dislikes Nietzsche, he will find Thomas

${ }^{1}$ Nietzsche, Philologica, Band I, pp. 332-3 (Kröner Auflage). 
Arnold saying much the same thing: "Undoubtedly I do not wish my mind to feel less or to think less upon public matters; ... and I am sure that the more active my own mind is, and the more it works upon great moral and political points, the better for the school." 1 To make the classics fully effective, we should be continually thinking how they touch our life, for which of our diseases they are a medicine, how they reinforce and supply our deficiencies, where they are an example and where a warning. No doubt the mere reading of them is something - the touch of their spirit passes on us. But it is better still when the gulf that separates us-it seems broad, but is narrow-can be bridged, and they no longer float detached in the air, a bubble world, beautiful, but remote and half unreal.

We can always detect the teacher who is not a ' modern man' by looking at the examination papers which he sets. Here are two examination papers on Greek drama (the questions in both have been set in Honour Classical Moderations at Oxford).

The first paper.

I. In what ways was the history of Greek Drama affected by (a) Sicyon, (b) Sicily?

${ }^{1}$ Life and Correspondence (sixth ed.), p. 367. 
2. What different views have been held as to the origin of the names tragedy and comedy?

3. Compare Sophocles and Euripides in their treatment of $(a)$ prologue, $(b)$ chorus, $(c)$ deus ex machina.

4. What do you know of the new comedy, its origin and development?

5. What are the main views held as to the construction of the stage and orchestra?

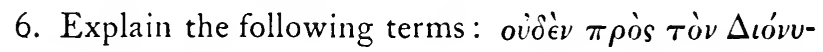
$\sigma o \iota^{\prime}, \kappa \cdot \tau \cdot \lambda$.

This is a 'dead' paper. A student ought, indeed, to be able to answer its questions, and some of these or similar questions ought to be in every examination paper on the subject, in order to test knowledge. But no paper should consist entirely of them, and the teacher who set it betrays himself. Who would guess from it that Greek drama, like all other, is a portraiture of human life by human beings, with lessons and models for a human world? Who would suspect that it is a living thing, and not a long-dead specimen bottled in a museum for the inspection of the curious? Now compare it with the second paper:

I. "There is no morbid pathology in Greek Tragedy." Discuss.

2. Which of the three dramatists is the best moral educator? 
3. Arrange the plot of Hamlet as a typical Greek tragedy, and suggest how Aeschylus, Sophocles and Euripides would have differed in their treatment of it.

4. Which of your plays do you consider the best acting play, and why?

5. "The essentially tragic fact is not so much the war of good with evil as the war of good with good." Compare this with the Aristotelian view of tragedy.

6. What would be the views of Aristotle on either

Shakespeare's historical plays

or

Wordsworth's theory of poetical diction?

Whatever faults this paper may have (it ignores too much the formal aspects of Greek tragedy, to which the first paper entirely confined itself), it is at any rate living, and betrays a teacher who is "a mediator between the great geniuses and the genius which is coming to be, between the great past and the future." 1

English education has to be grateful for such men as Arnold, Thring, Cory, Bowen, whose praise is in their biographies, and for many more who live in the memory and lives of their pupils. Reading Stanley's Life of Arnold, or Thring's Life and Letters, or Cory's Memoirs, we see how

${ }^{1}$ Nietzsche, l.c. $33^{2}$. 
fully they were 'modern men,' how continually they brought the past and the present together, how in their teaching they were not merely training taste or imparting a knowledge of dead languages, but forming characters and minds with all that was wise and noble in Greece and Rome. Such men are born and not made. Still, it is surely one of the greatest blunders of English secondary education, that we allow anyone to teach who has not studied the theory of teaching. Didascalus nascitur, non fit, we are told. No doubt; and the same is true of generals and sailors. Yet would anyone on that account dispense with Sandhurst or Dartmouth? Certainly Arnolds or Bowens will be great teachers without a course of pedagogy, though no one loses by learning the theory of his practice. But the teacher who really gains by being taught his trade is the average man who has no exceptional genius and who can be raised to a higher power by studying his subject and being forced to think about it; especially if he does so after a year's attempt to teach by the light of nature. It is possible here by taking thought to add, not perhaps a cubit, but a few inches to our stature. The excellence of the teaching in the big grammar schools is the best testimony to the value of the 


\section{REFORMS}

training of teachers. The public school, thanks to its prestige and its prospects, still gets the pick of the Universities as masters. Yet the teaching in it is certainly not superior-in many cases it is inferior-to that in important rate-aided schools, whose masters are compelled to be certified teachers, and have gained in efficiency and in interest in the art of imparting knowledge, by being compelled to think how it should be done. The born teacher may not gain so much, but under such a system there will not be so many flies in the educational ointment; and a few flies may spoil it.

In talking about reform, it is impossible not to mention Compulsory Greek, an institution embittered by an unhappy and fortuitous association with a body known (not very accurately) as the ' country clergy,' but really having more justification than is generally allowed. Not many of its supporters like it, or suppose that it is in itself desirable: its weaknesses have been pointed out so often that they need not be mentioned here. But it is worth while stating why some people, who are neither country clergy nor inveterate conservatives, still support it. Their reason is that without it Greek would be less widely taught to boys who 
can really profit by it, and that from a number of secondary schools it would disappear completely. At present it maintains in these schools a struggling existence, because the door of the Universities will only open to a knowledge of it. It is no use saying that we can rely on the virtues of Greek to keep it alive. In a sense they will do so; till civilisation disappears, some people will always discover and cherish its burning and shining light; but unless it has some artificial protection, the pressure of uninformed popular opinion will confine it within the narrowest limits. Doubtless in our big public schools in any circumstances some Greek would be taught. But they, after all, are only part of our school system. All over the country there are old grammar schools reviving and extending, and new secondary day schools coming into existence. An increasing number of the youth of the country is receiving education at these. What hope or chance have the classics at them? Some are in big mercantile centres, some in sleepy cathedral towns. The governors, where there are governors, are chiefly local magnates, the parents are business men and tradesmen. Education has not been their business, and they naturally take what is known as the 'commonsense point of 
view.' "Greek is a dead language ; you might as well learn Egyptian, Sanskrit or Hebrew." "Shakespeare got on very well without Greek." "What my boy wants is something which will be of use to him in business." "Why can't he learn modern languages - there are sure to be big openings in Russia after the war." "The modern world depends on science; the Greeks are all very well, but they are out of date now ; I want my boy taught science, to compete with the Germans." "The philosophy of Plato, a thinker who knew nothing of the world but a small bright patch round the Eastern Mediterranean, is scarcely worth our attention." What chance has Greek against these antique and familiar methods of begging the question? Read-I do not say the views on education of the man in the street-but the article of Sir H. Johnston in the Nineteenth Century Magazine for July; read the sort of arguments brought forward by some of the speakers, men of great eminence, at the Burlington House Conference; if such misconceptions, to use a very mild word, prevail in trees that are comparatively green, what will be found among the dry timber of business men in Leeds or Bristol or Southampton, who have never had occasion to think at all deeply about 
education? What chance will Greek have with them? Let anyone read the stories of Thring's struggles with the governors of Uppingham or Mr. Crees' Didascalus Patiens, and he will realise what the dangers and difficulties are.

That is why compulsory Greek has been supported, for instance, by a man as liberal and fair-minded as Mr. Warde Fowler, whom no one would accuse of obscurantism or partisanship. He states the case for it as follows: "I seriously doubt if we are well enough educated as a nation, to dispense with protection yet. It is a mere handful of English boys that learn Greek at the present moment, and it is a diminishing quantity, for the public schools, our only equivalent for the German Gymnasium (where Greek is now compulsory), are already beginning to let it go. Yet, in thinking about a vital subject like this, we are apt to take into our view the public schools and the old Universities only, forgetting that by far the greater number of our secondary schools and the majority of English Universities . . do scarcely any business in Greek at all. The average English parent has little respect for Greek now.... I have been reading Morley's Life of Cobden, and I see plainly that that admirable man 
lived so entirely in the present-a present so entirely divorced from all sympathetic understanding of the past-that if he had not been a genius and an enthusiast, he would have been no more useful in his country than the ordinary Philistine British parent. I don't see that he thought the classics worth a moment's consideration; and that is exactly the attitude of the ordinary English man of business who is not a Cobden. If that kind of attitude were to become universal in England, as I am apt to think it will, owing to the want of interest and of knowledge about education in this country, we should soon find ourselves still further behind the Germans and the Americans than we were before. If we were enthusiastic about education, we should put its real value on Greek." 1

Nobody, I believe, wishes that any boy who has no aptitude for Greek, should be forced to learn it. But they want some security that anyone who has a capacity for it and desires to learn it, should be able to do so. It is not enough for it to be taught

${ }^{1}$ An Oxford Correspondence of 1903, p. 94. Mr. Warde Fowler's book is equally remarkable for its grace of style, its criticisms of our University education, and its picture of the Oxford Tutorial system at its best. 
in our big public schools, where only a certain class of the population comes; if so, it remains an aristocratic study for the few. We wish to have some security that it should be within reach of all classes of the population who receive a secondary education. There are boys, we recognise, who will never want or need to learn it, but there are some for whom it will be as priceless a possession as it is for many of us to-day; and it is surely not unreasonable that these, if they cannot afford to go to a big residential school, should find a teacher of it in their local grammar or secondary school, and not grow up without a chance of acquiring it, till they reach an age when its acquisition becomes difficult or impossible.

At present the only method of securing this is compulsory Greek at the Universities. It means that certain schools, where Greek would have died under the pressure of commercialism, are forced to maintain it because it is necessary for Oxford and Cambridge. It is a makeshift method, for it only partially secures its end; it is hard on boys who wish to go to the Universities and have no aptitude for Greek, and in the case of these latter, it is a prostitution of a great subject. Yet it is no use ignoring the difficulty which causes its retention, 
or concealing from ourselves that if in present circumstances compulsory Greek be abolished, it is practically certain that Greek in the majority of our secondary schools will be not only a dead language but a dead study. Do we wish to run that risk?

In Germany this difficulty has never existed, because in every town of any size there is a local Gymnasium or secondary school, where boys not only can, but must learn Greek, and that throughout their whole school career. If they wish to avoid it, they can go to a Realschule; but at any rate they have the option; and no one in Germany can argue that compulsory Greek at the Universities is needed in order to keep the study of the language alive. A solution of our own problem might be found on these lines. The Board of Education at present insists on Physical Science being taught to all boys who attend rate-aided schools. It might insist that facilities for learning Greek should be given at all such schools. This would not mean that anyone need learn the language; it would merely secure that Greek was taught, and, if desired, could be learnt. If this were done, it would be possible almost without opposition to free those who should be freed from the burden of cramming up fragments of a 
language of which they have no appreciation and for which they have no gift. And surely it is not an excessive claim to make, that boys of all classes and of all secondary schools should have the chance, if they wish it, of studying a literature that is so great and a civilisation that has so deeply influenced the world. 


\section{WORKS ON THE HISTORY AND}

\section{CRITICISM OF GREEK LITERATURE, ETC.}

THE ANCIENT GREEK HISTORIANS (HARVARD LECTURES).

By Prof. J. B. Bury, Litt.D. 8vo. 7s. 6d. net.

SOME ASPECTS OF THE GREEK GENIUS. By S. H. Butcher, Litt.D., LL.D. Third edition. Cr. 8vo. 7s. net.

HARVARD LECTURES ON THE ORIGINALITY OF GREECE. By S. H. Butcher, Litt.D. Cr. 8vo. 7s. net.

ABRIDGED HISTORY OF GREEK LITERATURE. By MM. Alfred and MaUrice CRoIset. Translated by G. F. HeFFElBower. 8vo. Ios. 6d. net.

ARISTOPHANES AND THE POLITICAL PARTIES AT ATHENS. By MaURICE Croiset. Translated by James LOEB. 8vo. 7s. 6d. net.

PARAPHRASES AND TRANSLATIONS FROM THE GREEK. By the EARL OF Cromer. Cr. 8vo. 5s. net.

EURIPIDES AND THE SPIRIT OF HIS DRAMAS. By Prof. Paul Decharme. Translated by James Loeb, A.B. 8vo. I2s. 6d. net.

Hellenistic athens. An Historical Essay. By Prof. William Scott Ferguson. 8vo. i2s, net.

PAUSANIAS AND OTHER GREEK SKETCHES. By Sir J. G. Frazer, Litt.D. Gl. 8vo. 4s. net.

SCHOOLS OF HELlaS. AN Essay on the Practice and Theory of Ancient Greek Education, 600 to 300 B.c. By Kenneth J. Freeman. Edited by M. J. Rendall. With a Preface by A. W. Verrall, Litt.D. Illustrated. Second Edition. 8vo. 5s. net.

LANDMARKS OF HOMERIC STUDY. By the RT. HoN. W. E. Gladstone. Cr. 8vo. 2s. 6d.

HOMERIC SYNCHRONISM. AN INQUiRy INTO THE TIME and Place of Homer. By the Rt. Hon. W. E. Gladstone. Cr. 8vo. 6s.

GREEK DIVINATION. A STUdy OF ITS Methods AND Principles. By W. R. Halliday, B.A., B.Litt. Cr. 8vo. 5s. net.

LECTURES ON CLASSICAL SUBJECTS. By Prof. W. R. HARDIE, M.A. Cr. 8vo. 7s. net.

LONDON: MACMILLAN AND CO. LIMITED. 
WORKS ON THE HISTORY AND CRITICISM OF GREEK LITERATURE, ETc.-Continued.

GROWTH AND INFLUENCE OF CLASSICAL GREEK POETRY. By Sir R. C. JEbB, Litt.D., LL.D. Cr. 8vo. 7s. net.

COMPANION TO THE ILIAD FOR ENGLISH READERS. By W. LeAf, Litt.D. Cr. 8vo. 7s. 6d.

TROY: A STUDY IN HOMERIC GEOGRAPHY. By W. LEAF, Litt.D. Illustrated. 8vo. I2s. net.

HOMER AND HISTORY. By W. LEAF, Litt.D. With maps. 8vo. I2s. net.

A HISTORY OF CLASSICAL GREEK LITERATURE. By the Rev. J. P. Mahaffy, M.A., D.D. Two vols. C.r. 8vo. Vol. I. The Poets. With an Appendix on Homer by Prof. SAyce. In two parts. Vol. II. The Prose Writers. In two parts. 4s. 6d. each part.

THE OUTDOOR LIFE IN GREEK AND ROMAN POETS, AND KINDRED STUDIES. By the Countess Evelyn Martinengo Cesaresco. Ex. cr. 8vo. 6s. net.

CLASSICAL ESSAYS. By F. W. H. MYERS. Gl. 8vo. 4s. net.

LECTURES ON THE REPUBLIC OF PLATO. By R. L. Nettleship. Edited by G. R. Benson. 8vo. 8s. 6d. net.

GREeK Studies. By Walter Pater, M.A. Ex. cr. 8vo. ros. 6d. Library ed. 8vo. 75. 6d. net.

PLATO AND Platonism. By Walter Pater. Ex. cr. 8vo. 8s. 6d. Library ed. 8vo. 7s. 6d. net.

THE LAY OF DOLON. (The Tenth Book of Homer's ILIAD.) Some Notes on its Language, Verse, and Contents. By Alexander Shewan. 8vo. Ios. net.

LATIN POETRY. LECTURES DELIVERED IN I893 IN THE Johns Hopkins University. By R. Y. Tyrrell, Litt.D. Cr. 8vo. 7s. net.

ESSAYS ON GREEK LITERATURE. By R. Y. TyRRELl, Litt.D. Cr. 8vo. 4s. net.

TYPES OF TRAGIC DRAMA. By Prof. C. E. Vaughan. Ex. cr. 8vo. 5s. net.

THE VERSE OF GREEK COMEDY. By Prof. J. W. White. 8vo. r2s. net.

LONDON: MACMILLAN AND CO. LIMITED. 
. 
. 


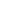




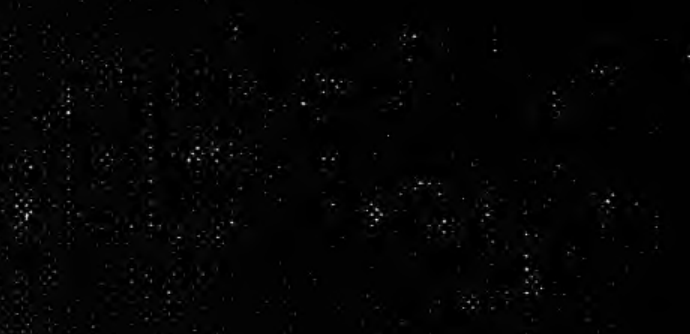

